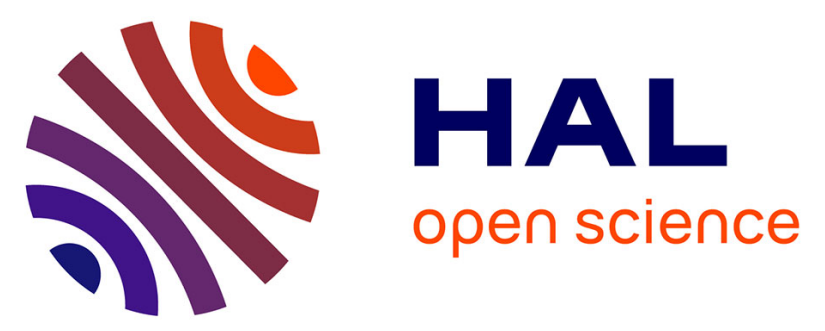

\title{
Synthesis and evaluation of new designed multiple ligands directed towards both peroxisome proliferator-activated receptor- $\gamma$ and angiotensin II type 1 receptor
}

Maxime Meyer, Sébastien Foulquier, François Dupuis, Stéphane Flament, Linda Grimaud, Daniel Henrion, Isabelle Lartaud, Gerald Monard, Isabelle Grillier-Vuissoz, Michel Boisbrun

\section{- To cite this version:}

Maxime Meyer, Sébastien Foulquier, François Dupuis, Stéphane Flament, Linda Grimaud, et al.. Synthesis and evaluation of new designed multiple ligands directed towards both peroxisome proliferatoractivated receptor- $\gamma$ and angiotensin II type 1 receptor. European Journal of Medicinal Chemistry, 2018, 158, pp.334-352. 10.1016/j.ejmech.2018.08.082 . hal-01905470

\section{HAL Id: hal-01905470 \\ https://hal.univ-lorraine.fr/hal-01905470}

Submitted on 20 Nov 2018

HAL is a multi-disciplinary open access archive for the deposit and dissemination of scientific research documents, whether they are published or not. The documents may come from teaching and research institutions in France or abroad, or from public or private research centers.
L'archive ouverte pluridisciplinaire HAL, est destinée au dépôt et à la diffusion de documents scientifiques de niveau recherche, publiés ou non, émanant des établissements d'enseignement et de recherche français ou étrangers, des laboratoires publics ou privés. 
Research paper

\title{
Synthesis and evaluation of new designed multiple ligands directed towards both peroxisome proliferator-activated receptor- $\gamma$ and angiotensin II type 1 receptor
}

\author{
Maxime Meyer ${ }^{\mathrm{a}}$, Sébastien Foulquier ${ }^{\mathrm{b}, 1}$, François Dupuis ${ }^{\mathrm{b}}$, Stéphane Flament ${ }^{\mathrm{c}}$, Linda Grimaud ${ }^{\mathrm{d}}$, Daniel Henrion ${ }^{\mathrm{d}}$, \\ Isabelle Lartaud $^{\mathrm{b}}$, Gérald Monard ${ }^{\mathrm{e}}$, Isabelle Grillier-Vuissoz ${ }^{\mathrm{c}}$, Michel Boisbrun ${ }^{\mathrm{a}, *}$ \\ a Université de Lorraine, CNRS, L2CM, F-54000, Nancy, France \\ ${ }^{\mathrm{b}}$ Université de Lorraine, CITHEFOR, F-54000, Nancy, France \\ c Université de Lorraine, CNRS, CRAN, F-54000, Nancy, France \\ d UMR CNRS 6214, INSERM U1083, CARFI facility, MITOVASC Institute, University of Angers, Angers, France

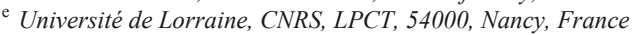

\section{A R T I C L E I N F O}

Article history:

Received 14 June 2018

Received in revised form 23 August 2018

Accepted 28 August 2018

Available online $\mathrm{xxx}$

Keywords:

Designed multiple ligands

$\mathrm{AT}_{1}$

PPAR- $\gamma$

Imidazole

Triazole

Chromane

\section{A B S T R A C T}

Because of the complex biological networks, many pathologic disorders fail to be treated with a molecule directed towards a single target. Thus, combination therapies are often necessary, but they have many drawbacks. An alternative consists in building molecules intended to interact with multiple targets, called designed multiple ligands. We followed such a strategy in order to treat metabolic syndrome, by setting up molecules directed towards both type 1 angiotensin II $\left(\mathrm{AT}_{1}\right)$ receptor and peroxisome proliferator-activated receptor- $\gamma$ (PPAR- $\gamma$ ). For this purpose, many molecules were prepared by merging both pharmacophores following three different strategies. Their ability to activate PPAR- $\gamma$ and to block $\mathrm{AT}_{1}$ receptors were evaluated in vitro. This strategy led to the preparation of many new PPAR- $\gamma$ activating and $\mathrm{AT}_{1}$ blocking molecules. Among them, some exhibited both activities, highlighting the convenience of this approach.

(C) 2018

\section{Introduction}

The until now dominant paradigm in the drug discovery field lies in the concept one disease/one target/one molecule. The aim is to develop new compounds able to modulate with a high selectivity the activity of a particular protein. Nevertheless, some complex pathologic disorders often fail to be correctly treated by one-target molecules because of the intrinsic redundancy and robustness of biological networks. An alternative consists in using combination therapies which may result in a synergistic effect. But combining several compounds can induce some problems, for example from a pharmacokinetic point of view. Thus, in the past decade another approach has emerged, consisting in setting up molecules intended to interact with multiple targets involved in the same pathology. This is usually designated as polypharmacology [1-6]. This approach has many advantages over the classical combination therapies. For example, it might be easier to predict the pharmacokinetic and the safety profile of a single molecule with dual activity compared to a combination of mul-

\footnotetext{
* Corresponding author.

Email address: michel.boisbrun@univ-lorraine.fr (M. Boisbrun)

${ }^{1}$ Present address: SF CARIM, School for Cardiovascular Diseases, Maastricht University, 6229ER Maastricht, The Netherlands.
}

tiple compounds and furthermore, the patient compliance will increase. In addition, the regulatory requirements for drug combinations are more complex than for a single molecule. Cancer [7] and central nervous system pathologies [8-11] are typical complex disorders where polypharmacology is of great help. Besides, metabolic syndrome $[12,13]$ is also a complex pathology combining many disorders like dyslipidemia, obesity, insulin resistance, and hypertension. There is no marketed drug able to treat all these factors simultaneously, thus combinations are often clinically used albeit as evoked before, a unique molecule able to address most of these elements would be highly beneficial. In this sense, it was discovered that telmisartan, an angiotensin II receptor blocker (ARB) used as an antihypertensive agent, is also able to bind and activate peroxisome proliferator-activated receptor- $\gamma$ (PPAR- $\gamma$ ), resulting in beneficial effects in glucose and lipid metabolism [14-19]. New molecules exhibiting structural analogy with telmisartan were later developed, yielding compounds with moderate to potent activity on PPAR- $\gamma$, while keeping type 1 angiotensin II receptor $\left(\mathrm{AT}_{1}\right)$ blocking ability [20-23].

Besides, another approach would consist in merging in one molecule both ARB and PPAR- $\gamma$ agonist pharmacophores, thus creating a Designed Multiple Ligand (DML) as defined by Morphy and Rankovic [1-3]. One such process was attempted once [24] but was not so successful since an essential feature of ARBs, the $4^{\prime}$-methyl- 
biphenyl-2-carboxylate moiety was absent from the resulting molecule. Fig. 1 shows some examples of ARBs, which usually harbor this moiety (where the carboxylate may be replaced by a tetrazole bioisostere), linked to a heterocyclic structure. Fig. 2 shows some examples of PPAR- $\gamma$ agonists, which usually also contain a heterocyclic feature, linked to a benzylthiazolidine-2,4-dione or a tyrosine derivative. When merging these two pharmacophores, one may obtain a putative dual ARB/PPAR- $\gamma$ agonist molecule as shown in Fig. 3, as both pharmacophores contain a heterocyclic template. In order to obtain such DML, we envisioned three strategies A, B, and C (Fig. 3).

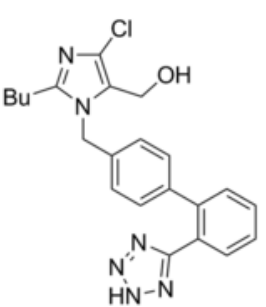

Losartan

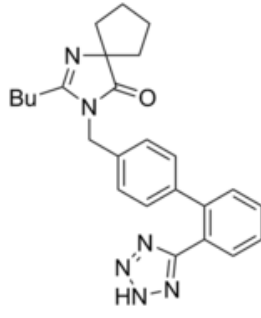

Irbesartan

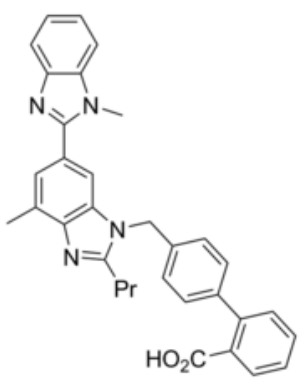

Telmisartan
Fig. 1. Some marketed molecules belonging to the ARB family.<smiles>Cc1c(C)c2c(c(C)c1O)CCC(C)(COc1ccc(CC3SC(=O)NC3=O)cc1)O2</smiles><smiles>CCc1ccc(CCOc2ccc(CC3SC(=O)NC3=O)cc2)nc1</smiles>

Pioglitazone
Strategy A consists in using an ARB molecule such as losartan and grafting on the primary alcohol group a part of a PPAR- $\gamma$ pharmacophore. Such approach based on losartan have already been successfully achieved, in order to obtain dual ARB-antioxidant $[25,26]$ or ARB-NO releasing compounds [27]. Strategy B consists in using a heterocycle as a template and to graft on it two chemical moieties: one dedicated to angiotensin II type $1\left(\mathrm{AT}_{1}\right)$ receptor and the other to the PPAR- $\gamma$ one. Strategy C uses troglitazone, a well-known PPAR- $\gamma$ agonist to which will be linked a 4'-methylbiphenyl-2-carboxylate moiety in order to add ARB activity.

In this article we report the synthesis of new DML which were prepared according to these three strategies. The effects of these molecules towards both receptors were evaluated in vitro. Besides, docking experiments were achieved in order to better understand interactions between these molecules and the PPAR- $\gamma$ receptor.

\section{Chemistry}

Following strategy A, we intended to graft a benzylthiazolidine-2,4-dione moiety to the molecule of losartan (Scheme 1). Commercially available losartan (potassium salt) was first protected on the tetrazole ring with a trityl group, following a procedure which was used to protect imidazoles [28]. As attempts to activate the primary alcohol as a triflate failed, we coupled compound 1 with 4-hydroxybenzaldehyde using Mitsunobu conditions, giving 2, then Knoevenagel condensation with thiazolidine-2,4-dione (TZD) yielded $\mathbf{3}$.

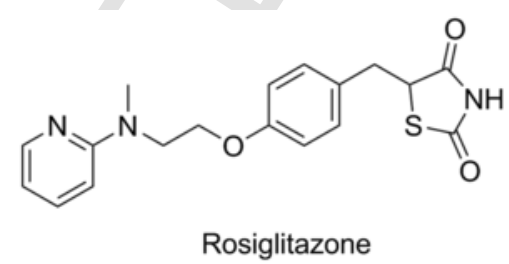<smiles>COC(=O)c1ccccc1N[C@H](Cc1ccc(OCCc2nc(-c3ccccc3)oc2C)cc1)C(=O)O</smiles>

GW7845

Fig. 2. Some PPAR- $\gamma$ agonists; only pioglitazone is still marketed in some countries as an antidiabetic.

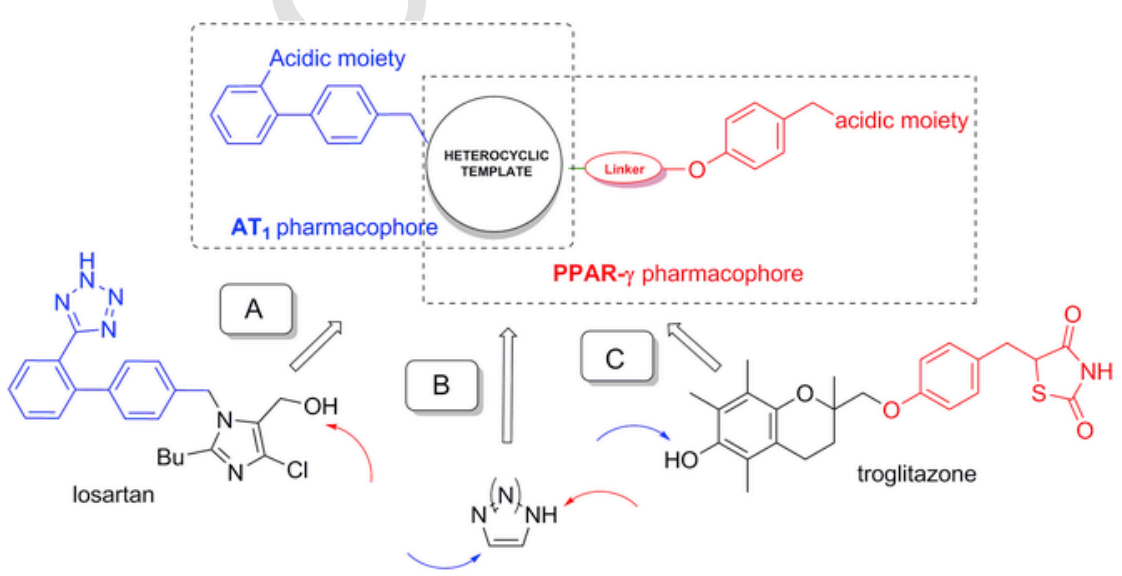

Fig. 3. Three strategies devoted to the design new ARB/PPAR- $\gamma$ agonist DMLs. 


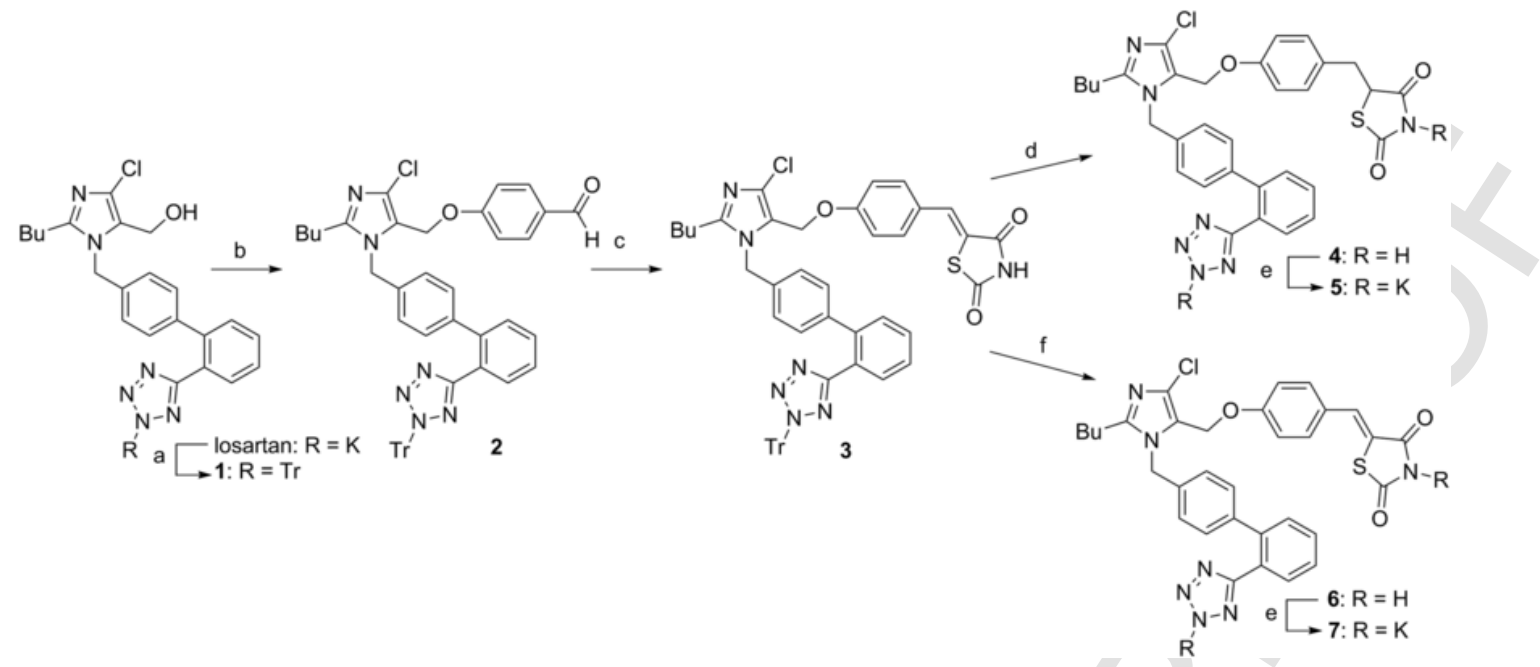

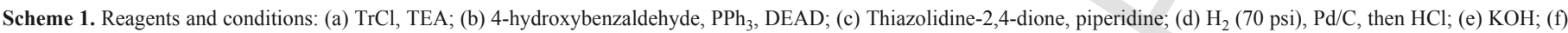
$\mathrm{HCl}$.

Such unsaturated compound is sought to be PPAR- $\gamma$ inactive [29], thus it had to be reduced. Nevertheless, we intended to isolate both reduced and unreduced compounds for comparison purposes. Reducing such a benzilidenethiazolidine-2,4-dione derivative needed 4 days reaction under 70 psi hydrogen atmosphere, presumably due to partial poisoning of the palladium catalyst by the sulfur atom of the TZD ring. Not surprisingly, according to ${ }^{1} \mathrm{H}$ NMR about $40 \%$ of the trityl group was simultaneously removed. Thus, after reaction workup, this partial deprotection was subsequently completed by acidic treatment in order to get the target compound $\mathbf{4}$. Compound $\mathbf{3}$ was also directly deprotected to give unsaturated compound $\mathbf{6}$. In order to get water-soluble compounds, salification of $\mathbf{4}$ and $\mathbf{6}$ with $\mathrm{KOH}$ respectively gave $\mathbf{5}$ and 7.

In order to modulate the distance between the benzylTZD and the losartan parts of the molecule, we introduced a linker at this position, following Scheme 2. Losartan was first partially oxidized to aldehyde 8 according to a slight modification of a reported procedure [30], and the tetrazole was protected, giving $\mathbf{9}$. Wittig-Horner-type reaction was achieved, with a procedure previously used with a similar substrate [31], affording 10 as a unique $(E)$ isomer with an excellent yield. Catalytic reduction of this compound followed by tritylation gave the expected compound 12 as a minor product (14\% isolated yield), since dehalogenated 11 was predominantly isolated (48\% isolated yield). Subsequently, 11 was reduced with $\mathrm{LiAlH}_{4}$, giving 13 with an excellent yield. In order to get the expected chlorinated alcohol, the direct reduction of alcene $\mathbf{1 0}$ to $\mathbf{1 4}$ with $\mathrm{LiAlH}_{4}$ was achieved with a modest yield $(25 \%)$ yet permitting to continue the synthesis. In order to minimize the number of reaction steps, we prepared the reported [32] 5-(4-hydroxybenzyl)-3-tritylthiazolidine-2,4-dione and coupled it to 13 and 14, affording 15 and $\mathbf{1 7}$. The former was isolated pure in $43 \%$ yield, but the latter could not be separated from remaining traces of starting materials. At this stage, we noticed that the removal of both trityl groups in acidic medium proceeded very differently. According to ${ }^{1} \mathrm{H}$ NMR, we noticed that the trityl moiety harbored by the TZD nitrogen was removed in 50\% TFA in dichloromethane in a few minutes, whereas the trityl moiety harbored by the tetrazole was almost not affected. Failed attempts using molecule $\mathbf{1}$ in the same conditions confirmed this fact. Thus, a two-steps reaction procedure (TFA, then $\mathrm{HCl})$ was necessary to remove both protecting groups. Final salification with $\mathrm{KOH}$ afforded expected compounds $\mathbf{1 6}$ and $\mathbf{1 8}$.
We also envisioned joining the losartan subunit to the benzylTZD part via an ester linker (Scheme 3). Thus, compound $\mathbf{1 0}$ was saponified and the resulting 19 was coupled with 5-(4-hydroxybenzyl)-3-tritylthiazolidine-2,4-dione using PyBOP, giving 20. Treatment with TFA easily gave mono-deprotected 21 which was further deprotected with $\mathrm{HCl}$, yielding $\mathbf{2 2}$. We used the same strategy in order to introduce a tyrosine-type pharmacophore, as in GW7845 (Fig. 2) [33]. We directly applied on the tertiobutyl ester of L-tyrosine the procedure which was previously used on more complex substrates. Thus, it was condensed with 2-Oxo-cyclohexanecarboxylic acid methyl ester, and then oxidized to give 23. PyBOP coupling of the latter with 19 gave 24 which was further deprotected to give $\mathbf{2 5}$. As unsaturated benzylpyrazole acylsulfonamides were reported to exhibit interesting PPAR- $\gamma$ activity [31], we also introduced an acylsulfonamide function on the losartan template. 1-Pentanesulfonamide was prepared as previously reported [34] and coupled with 19 using DCC/DMAP. Subsequent deprotection gave target molecule 27. Besides, it has been reported [35] that despite losartan is a weak activator of PPAR- $\gamma$, one of its metabolites, i.e. losartan-aldehyde, is a potent one. This may be due to the higher lipophilic character of the latter (calculated $\operatorname{cog} \mathrm{P}=5.83$ versus 5.32 for losartan, see experimental part). Thus, we intended to still increase this property by preparing dodecyl-losartan (calculated $\operatorname{clog} \mathrm{P}=10.28$ ) as depicted in Scheme 3. Thus, dodecylmethanesulfonate [36] was reacted with $\mathbf{1}$ to give ether $\mathbf{2 8}$ which was deprotected to give target compound $\mathbf{2 9}$.

In order to follow strategy B, we used imidazole and triazole heterocycles as central templates and grafted on them chemical moieties intended to hold $\mathrm{AT}_{1}$ and PPAR- $\gamma$ activities. We already reported [37] the three-steps synthesis of unsaturated derivatives $\mathbf{3 0}$ and $\mathbf{3 1}$ from freshly prepared tert-butyl-4' (bromomethyl)biphenyl-2-carboxylate and commercially available imidazole derivatives (Scheme 4). Reduction of the double bond and removal of tert-butyl ester afforded $\mathbf{3 2}$ and 33.

It was challenging to lengthen the distance between the imidazole and the benzylthiazolidine-2,4-dione moiety. Thus, we used the same strategy as for losartan derivatives (Scheme 5). The primary alcohol function of a commercial imidazole derivative was first oxidized and the resulting aldehyde $\mathbf{3 4}$ was submitted to Wittig-Horner-type reaction, followed by catalytic reduction to 35 , and then $\mathrm{LiAlH}_{4}$ reduction, affording alcohol 36. Alkylation with tert-butyl-4' (bromomethyl)biphenyl-2-carboxylate predominantly afforded 37 which 
<smiles>OCc1c(Cl)nc(Cc2ccccc2)n1Cc1ccc(-c2ccccc2-c2nn[nH]n2)cc1</smiles>

losartan<smiles>CC(C)(C)c1nc(Cl)c(C=O)n1Cc1ccc(-c2ccccc2-c2nn[nH]n2)cc1</smiles>

8<smiles>[3H]n1nnc(-c2ccccc2-c2ccc(Cn3c(CC(C)C)nc(Cl)c3C=O)cc2)n1</smiles><smiles>CCOC(=O)/C=C/c1c(Cl)nc(CBr)n1Cc1ccc(-c2ccccc2-c2nnn([Tl])n2)cc1</smiles>

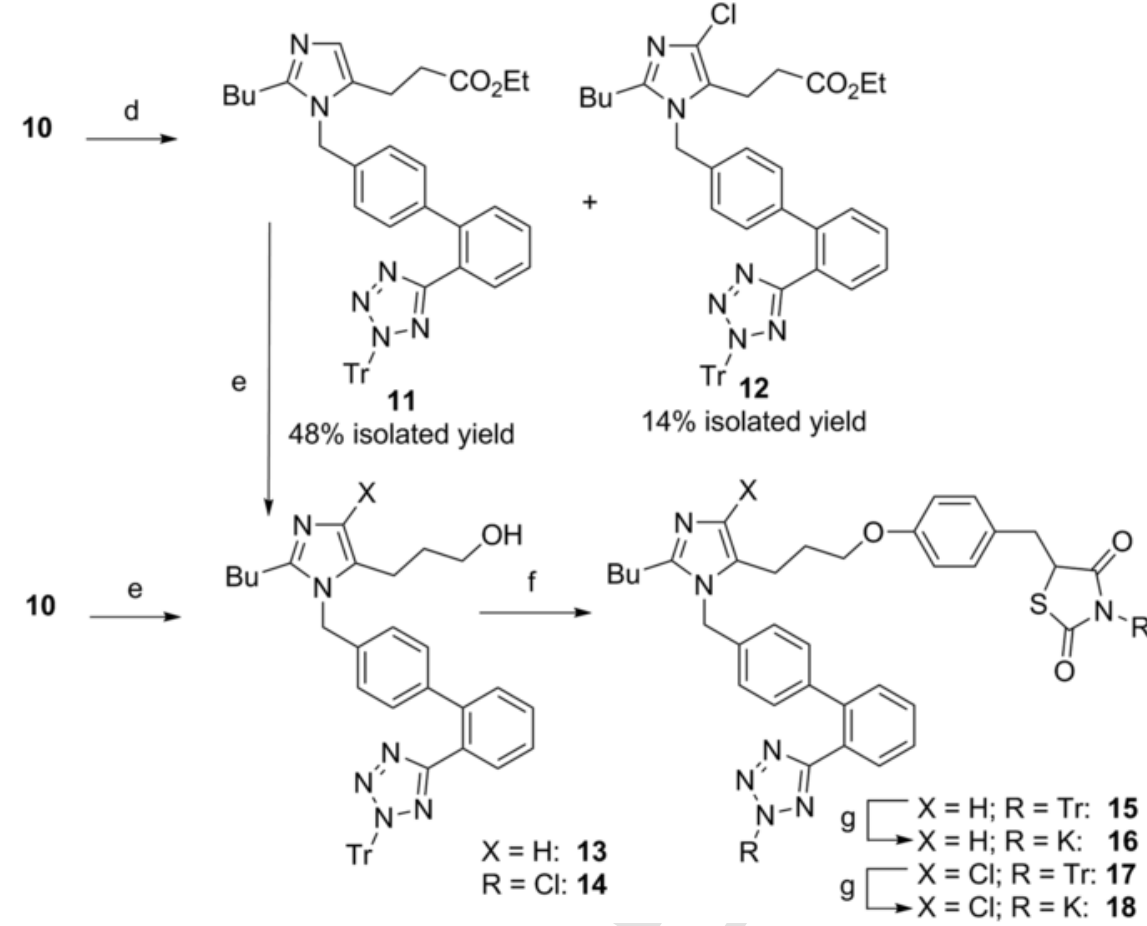

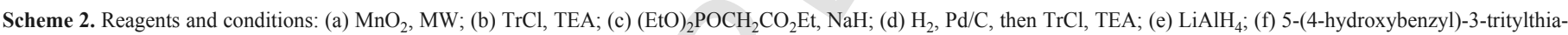
zolidine-2,4-dione, $\mathrm{PPh}_{3}$, DEAD; (g) TFA, then $\mathrm{HCl}$, then $\mathrm{KOH}$.

could be separated from minor regioisomer $\mathbf{3 8}$ by chromatography. Adjunction of the benzylthiazolidine-2,4-dione proceeded as previously. Simultaneous removal of trityl and tertiobutyl ester, followed by salification afforded 39 .

We also used 1,2,3-triazole as a heterocyclic template in order to follow strategy B (Scheme 6). We already reported [37] the synthesis of unsaturated derivatives $\mathbf{4 0}$ and $\mathbf{4 1}$ by a "click chemistry" cycloaddition reaction from tert-butyl-4' (azidomethyl)biphenyl-2-carboxylate and appropriate alkynes, followed by condensation with TZD. Catalytic hydrogenation easily gave saturated compounds $\mathbf{4 2}$ and $\mathbf{4 3}$. Subsequent acidic cleavage of the ester followed by salification gave the expected target compounds $\mathbf{4 4}$ and $\mathbf{4 5}$.

We then intended to get a triazole analogue bearing a butyl group as in losartan (Scheme 7). This needed to achieve a 1,3-dipolar cycloaddition between the same azide as previously and a disubstituted alkyne. Thus, $\mathrm{Cu}(\mathrm{I})$ catalysis was not possible, and classical Huisgen cycloaddition reaction had to be used. Hept-2-ynal was prepared as reported [38] and was reacted with tert-butyl-4' (azidomethyl)biphenyl-2-carboxylate following a reported procedure [39]. Since very low yields of the expected compounds were obtained, we tried to use microwave irradiation, using a reported procedure [40]. ${ }^{1} \mathrm{H}$ NMR analysis of the crude mixture revealed that both regioisomers were formed in very low amounts, much azide compound was remaining, while no alkyne was still present, presumably due to decomposition. Thus, a total of five irradiation sequences were achieved, adding each time some more alkyne. According to ${ }^{1} \mathrm{H}$ NMR of the final crude mixture, and compared to the remaining azide, $33 \%$ of isomer 46 and $10 \%$ of $\mathbf{4 7}$ were obtained, which after column chromatography yielded respectively $19 \%$ and $3 \%$ of these compounds. Reduction of aldehyde 46 gave easily alcohol 48 which after Mitsunobu reaction afforded 49. Acidic deprotection finally gave target compound $\mathbf{5 0}$.

In order to follow strategy $\mathrm{C}$, we intended to graft a $4^{\prime}$-methylbiphenyl-2-carboxylate moiety on a molecule of troglitazone. We already reported [37] a three-step synthesis of unsaturated compounds 51 and 52. Catalytic hydrogenation of 51 afforded reduced compound 53 which after acid deprotection gave target compound 54 (Scheme $8)$.

Besides, we intended to set up an analog of 54, where the benzylthiazolidine-2,4-dione is replaced by a tyrosine-type moiety as in GW7845 (Fig. 2). Thus, we coupled the already reported [37] molecule 55 with tyrosine derivative 23 (Scheme 9), affording 56. Cleavage of both $t$-butyl esters with TFA at room temperature was quite troublesome, since we observed a partial concomitant cleavage of the 


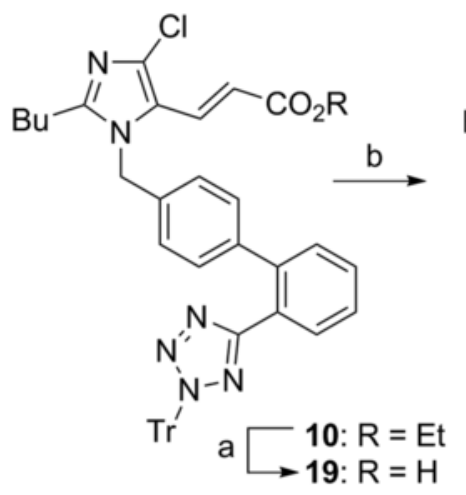

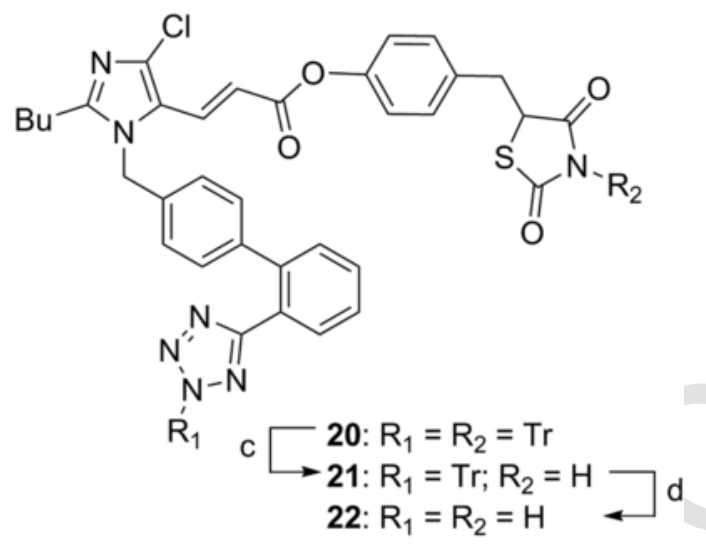<smiles>CCCCC(=O)OCC(N)Cc1ccc(O)cc1</smiles>

23

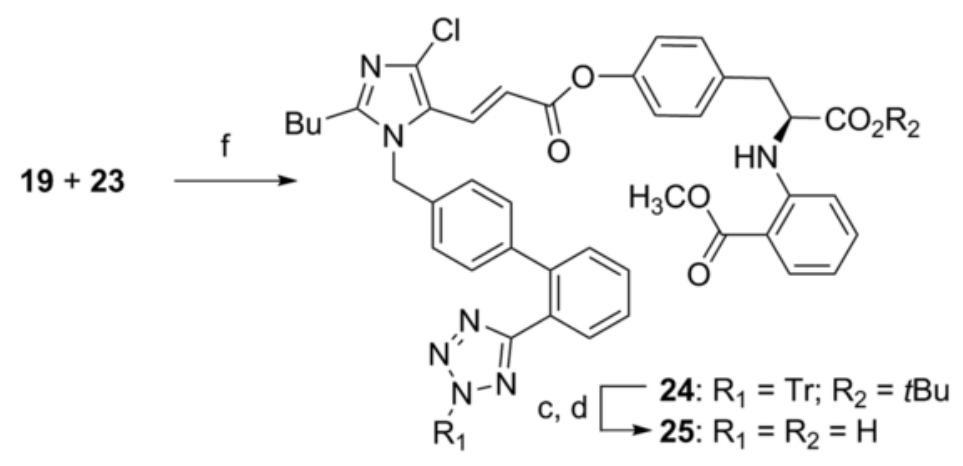

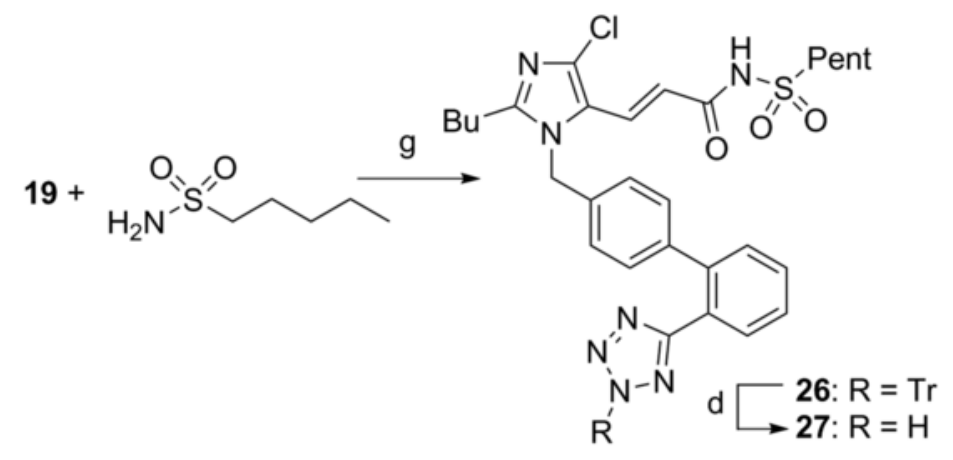

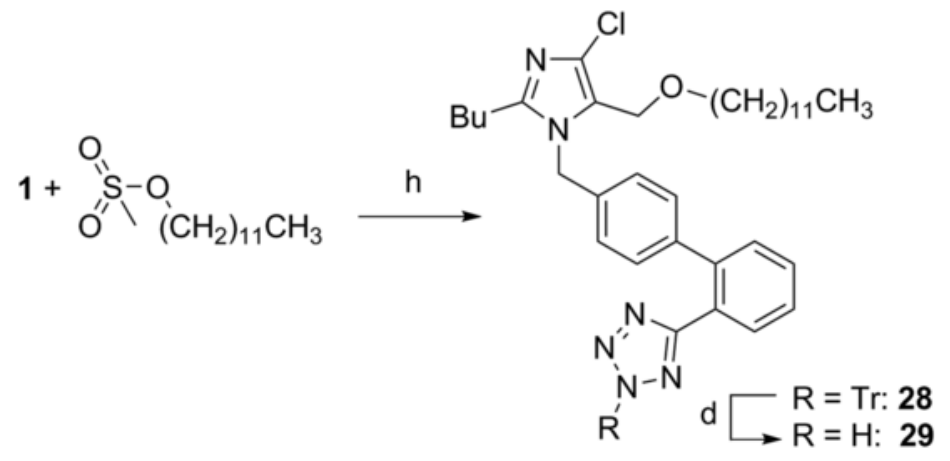


ether function linking the biphenyle moiety to the chromane heterocycle. Thus, after purification target compound $\mathbf{5 7}$ was obtained with only $23 \%$ yield, together with cleaved compound $\mathbf{5 8}$ (27\% yield).

\section{Biological studies}

Our aim was to set up molecules able to both activate PPAR- $\gamma$ and block the Angiotensin II type $1\left(\mathrm{AT}_{1}\right)$ receptor. First, we evaluated the ability of the various target compounds to activate the PPAR- $\gamma$ receptor. This was performed using MCF-7 cells transfected with a pPPRE3tk-luc reporter (see experimental part). We used rosiglitazone (RGZ) as a positive control, telmisartan (TEL) as it is an ARB for which a PPAR- $\gamma$ activating ability has already been proven, and losar$\tan (\mathrm{LOS})$ as the weak activator [15], which was used as the threshold to compare the tested molecules with. The results are shown in Fig. 4.

As expected, reference RGZ is a potent PPAR- $\gamma$ activator as it induces an almost 3-fold transactivation compared to the control. Telmisartan is also a potent activator, albeit less potent than RGZ. Not surprisingly, losartan did not induce much luciferase induction compared to the control. Thus, following strategy A, we intended to add to the losartan structure a benzylthiazolidine-2,4-dione moiety which is present in many PPAR- $\gamma$ agonists (Scheme 1). Disappointingly, molecule 5 was not more active than losartan. It was also the case for molecule 7, but this was actually expected since 7 has a double bond next to the TZD ring, which is known to be detrimental to the activity [29]. We then intended to expand the link between both parts of the molecule in order to facilitate the interactions with the PPAR- $\gamma$ receptor, but the resulting molecules $\mathbf{1 6}$ and $\mathbf{1 8}$ (Scheme 2) were even less active. Nevertheless, we replaced the flexible linker present in $\mathbf{1 8}$ by a more rigid unsaturated ester, thus providing compound $\mathbf{2 2}$ (Scheme 3). This resulted in a slight increase in its potency. Losartan was also coupled with other structures via the same linker (Scheme 3 ). Tyrosine derivative $\mathbf{2 3}$ which was used in reported very active molecules [33] was linked to losartan to give $\mathbf{2 5}$ and an acylsulfonamide moiety which was also reported to give good results [31] gave $\mathbf{2 7}$ after coupling with losartan. Both compounds were also barely more active than losartan. Finally, a good result was obtained when applying a very simple approach based on the increase of the lipophilic nature of losartan. The simple grafting of a dodecyl chain on its primary alcohol function afforded 29 which revealed to be a quite good PPAR- $\gamma$ activator with an almost two-fold induction of the luciferase activity.

Strategy B afforded imidazole compounds which were similar from previously described compounds $\mathbf{5}, \mathbf{1 6}$, and $\mathbf{1 8}$, but since they were not prepared from losartan, they exhibited two structural differences (Schemes 4 and 5). First, as in telmisartan, the acidic moiety on the biphenyl core of the new molecules was a carboxylic acid function instead of a tetrazole. Second, the grafting of the benzylthiazolidine-2,4-dione occurred on an adjacent carbon atom of the imidazole ring, compared to $\mathbf{5}, \mathbf{1 6}$, and $\mathbf{1 8}$. The resulting compound $\mathbf{3 2}$ was not active, but $\mathbf{3 3}$ was slightly more potent than losartan. This difference may be attributed to the presence in $\mathbf{3 3}$ of a butyl chain, increasing the lipophilic nature of the compound compared with 32. Adding a spacer between both pharmacophores of the molecule yielded 39 and once again, this strategy proved to be ineffective since $\mathbf{3 9}$ was less active than 33. Strategy B also afforded triazole analogs of the pre- ceding compounds. Unfortunately, resulting 44 was not more active than losartan and $\mathbf{4 5}$ did not show any activity. However, their precursors $\mathbf{4 2}$ and $\mathbf{4 3}$, harboring $t$-bu ester protecting groups exhibited a two-fold increase in luciferase activity, suggesting that the carboxylate group is detrimental to the activity, compared to the lipophilic $t$-bu ester. Finally, compound $\mathbf{5 0}$ with a free carboxylate group, but holding a n-butyl group on the triazole heterocycle was modestly more active than losartan. Once again, the presence of an additional lipophilic group may explain this increase in activity compared to 44 and $\mathbf{4 5}$. Strategy C starting from a troglitazone (TGZ) core afforded compounds 51-54. Surprisingly, compounds 51 and $\mathbf{5 2}$ were quite active despite the presence of a double bound next to the TZD ring. From the reduced compounds, deprotected 54 exhibited the best transactivation potency of the series, at the level of the reference RGZ, despite the presence of a free carboxylate group. The replacement of the benzylthiazolidine-2,4-dione by a tyrosine derivative afforded analog $\mathbf{5 7}$ which was less active, but the side-product $\mathbf{5 8}$ also exhibited a strong activity. One should consider that $\mathbf{5 8}$ is structurally very similar to a tyrosine-derived compound which was reported to be a strong PPAR- $\gamma$ activator [41].

A second step of this study consisted in evaluating the ability of the molecules to block the $\mathrm{AT}_{1}$ receptor. As angiotensin II induces a rapid intracellular calcium release, we proceeded by measuring in vitro the inhibition of this phenomenon by our compounds in rat aortic smooth muscle cells using a fura- 2 am molecular probe (see experimental part). In order to rapidly distinguish between active and non-active molecules, a first rough test was conducted with a unique concentration of $10 \mu \mathrm{M}$. In order to identify putative potent compounds, only molecules devoid of any protecting group were selected for this evaluation. Along with control losartan, we tested compounds $\mathbf{5}, \mathbf{7}, \mathbf{1 6}, \mathbf{1 8}$, $22,25,27,29,32,33,39,44,45,50,54$, and 57 . Angiotensin II induced a strong increase of the fluorescence compared to the control and as expected, losartan reduced this effect by $78 \%$ (see supporting information, Fig. S1). Among the tested molecules, whatever the synthetic strategy used (A, B, or C), only molecules 5 to 39 were considered active as they reduced by at least $50 \%$ the increase of the fluorescence induced by angiotensin II. All these active molecules contained an imidazole heterocycle. Triazole derivatives from strategy $\mathrm{B}(\mathbf{4 4}, \mathbf{4 5}$, 50), or chromane-containing troglitazone analogs from strategy $\mathrm{C}(\mathbf{5 4}$, 57) did not exhibit any activity. After this first sorting, the active molecules (5-39) were selected in order to check their potency at various concentrations, thus giving access to their $\mathrm{IC}_{50}$. For homogeneity reasons, during each experiment, losartan activity was also tested. Results are expressed in Table 1 as the ratio of the $\mathrm{IC}_{50}$ of the considered compound to the $\mathrm{IC}_{50}$ of losartan.

The addition of a benzylthiazolidine-2,4-dione to the molecule of losartan, yielding compound $\mathbf{5}$, resulted in a slight drop of activity, but the addition of a linker between the two parts of the molecule, yielding $\mathbf{1 6}$ and $\mathbf{1 8}$ improved the activity which was even better than that of losartan for 18. A more rigid linker was quite detrimental to the activity (compare $\mathbf{1 8}$ to $\mathbf{2 2}$ ), while keeping the activity to a fair level. The introduction of a bulky tyrosine derivative (25) showed little effect, but an acylsulfonamide (27) was more detrimental to the activity. The simple $O$-alkylation of losartan with a dodecyl chain yielded 29 which was even less active. Nevertheless, one should notice that the $\mathrm{AT}_{1}$ receptor is quite tolerant to structural modifications made on the primary alcohol function of losartan, which in this study 
<smiles>[R]COC(=O)c1ccccc1-c1ccc(CBr)cc1</smiles>

$$
\begin{aligned}
& \mathrm{R}=\mathrm{H}: 30 \\
& \mathrm{R}=\mathrm{Bu}: 31
\end{aligned}
$$

$\mathrm{R}=\mathrm{H}: 32$

$\mathrm{R}=\mathrm{Bu}: 33$

Scheme 4. Reagents and conditions: (a) See Ref. [37]; (b) $70 \mathrm{psi} \mathrm{H}_{2}$, Pd/C, then TFA, then $\mathrm{KOH}$.<smiles>CCOC(=O)CCc1c[nH]c(C(C)(C)C)n1</smiles>

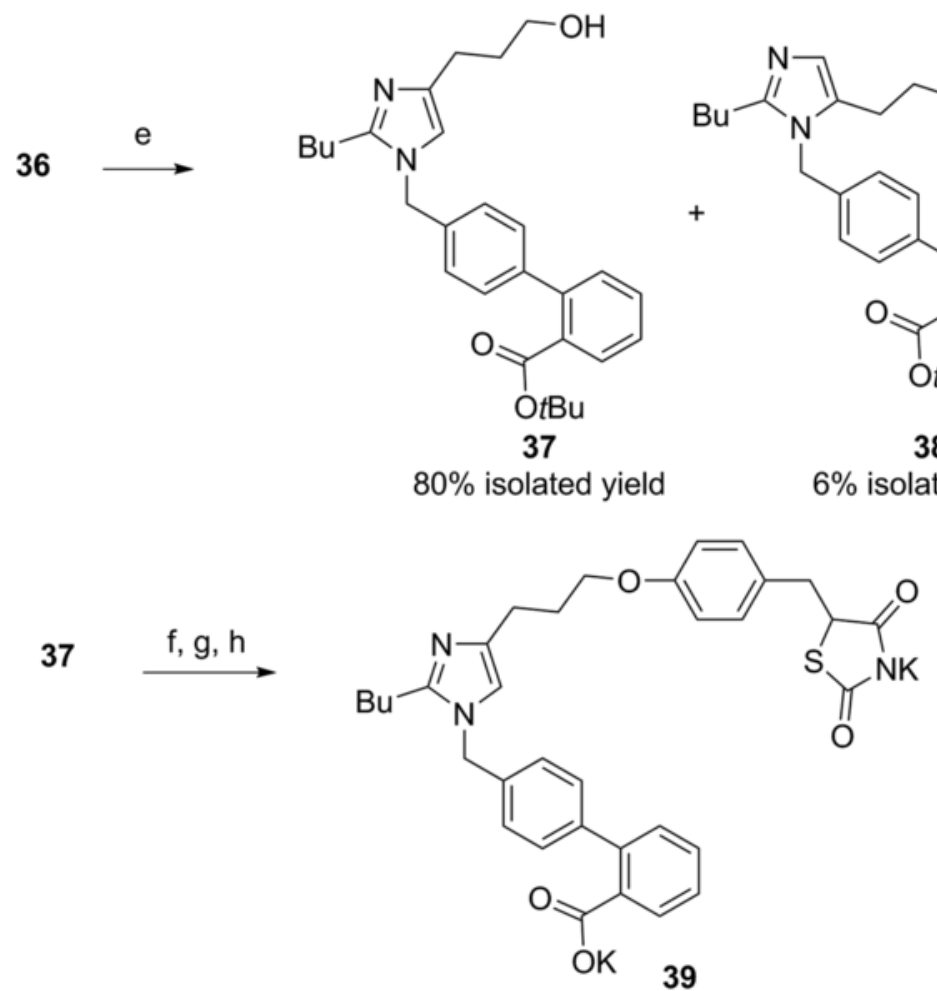

Scheme 5. Reagents and conditions: (a) $\mathrm{MnO}_{2}$, MW; (b) (EtO) ${ }_{2} \mathrm{POCH}_{2} \mathrm{CO}_{2} \mathrm{Et}$, NaH; (c) $\mathrm{H}_{2}$, Pd/C; (d) $\mathrm{LiAlH}_{4}$; (e) tert-butyl-4' (bromomethyl)biphenyl-2-carboxylate, $\mathrm{K}_{2} \mathrm{CO}_{3}$; (f) 5-(4-hydroxybenzyl)-3-tritylthiazolidine-2,4-dione, $\mathrm{PPh}_{3}$, DEAD; (g) TFA; (h) KOH.

always afforded active to very active molecules. This tendency was already noticed in previous studies [25-27,42]. Imidazole derivatives 32, 33, and 39 were not prepared from losartan, and thus exhibited a different geometry, which resulted in different structure-activity relationships (SAR). Indeed, compound $\mathbf{3 2}$ showed a fair activity, while introducing a butyl group at the 2-position of the imidazole ring, giving 33, induced a decrease of the activity. This is much different from the classical SARs previously observed in the losartan family of compounds [42]. Furthermore, the addition of a linker between the two parts of the molecule, yielding $\mathbf{3 9}$ was this time detrimental to the ac- tivity, whereas the opposite result was observed in the losartan series (compare $\mathbf{5}$ to $\mathbf{1 6}$ and 18).

\section{Docking studies and discussion}

To rationalize our experimental results, we have performed docking simulations on the PPAR- $\gamma$ receptor of eight different compounds representative of our findings: Rosiglitazone, Losartan, compounds 29, 42, 43, 44, 45, and 54. The reference X-ray structure has been chosen as PDB code 2 PRG. It contains rosiglitazone co-crystallized 


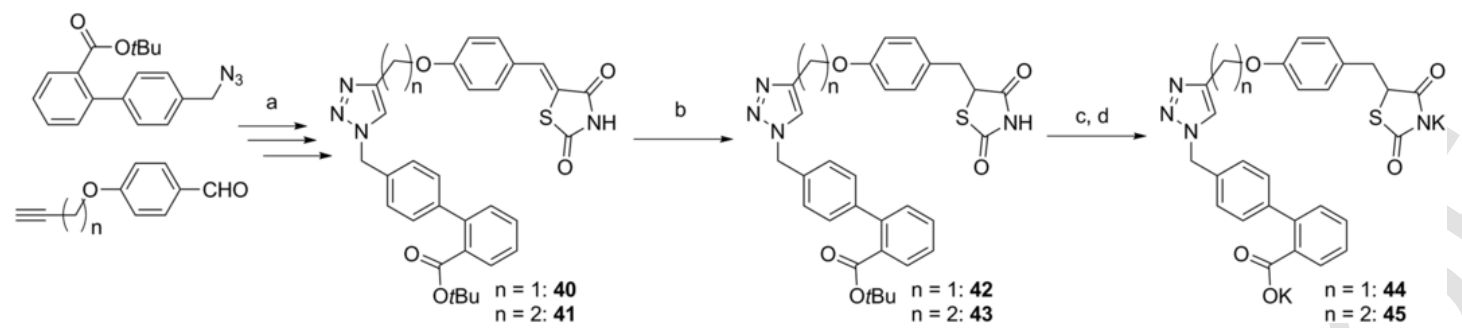

Scheme 6. Reagents and conditions: (a) See Ref. [37]; (b) 70 psi $\mathrm{H}_{2}, \mathrm{Pd} / \mathrm{C}$; (c) TFA; (d) KOH.

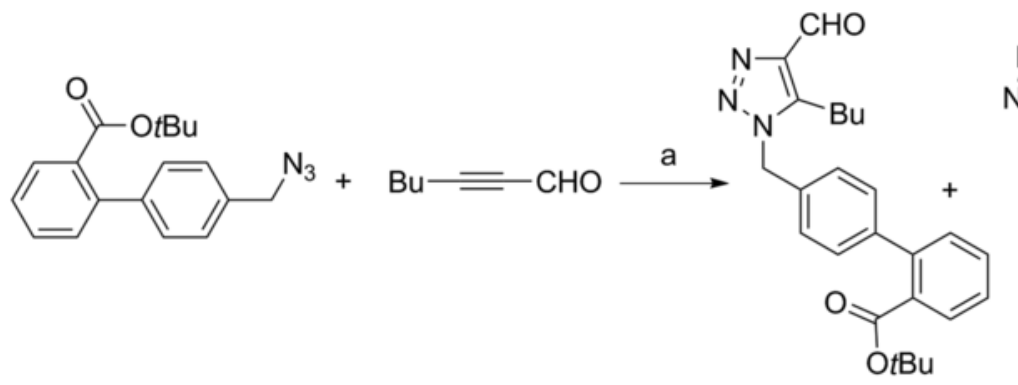

46<smiles>CCCCOC(=O)c1ccccc1-c1ccc(Cn2nnc(Br)c2C=O)cc1</smiles>

47

$19 \%$ isolated yield

$3 \%$ isolated yield<smiles>[R20]C(=O)c1ccccc1-c1ccc(Cn2nnc(COc3ccc(CC4SC(=O)N([R1])C4=O)cc3)c2CCCCCC)cc1</smiles>

48

$$
\begin{aligned}
& \mathrm{d} \longrightarrow \text { 49: } \mathrm{R}_{1}=\mathrm{Tr} ; \mathrm{R}_{2}=t \mathrm{Bu} \\
& \longrightarrow \text { 50: } \mathrm{R}_{1}=\mathrm{H} ; \mathrm{R}_{2}=\mathrm{H}
\end{aligned}
$$

Scheme 7. Reagents and conditions: (a) Micro-wave irradiation; (b) $\mathrm{NaBH}_{4}$; (c) 5-(4-hydroxybenzyl)-3-tritylthiazolidine-2,4-dione, $\mathrm{PPh}_{3}$, $\mathrm{DEAD}_{\text {; }}$ (d) $\mathrm{TFA}$

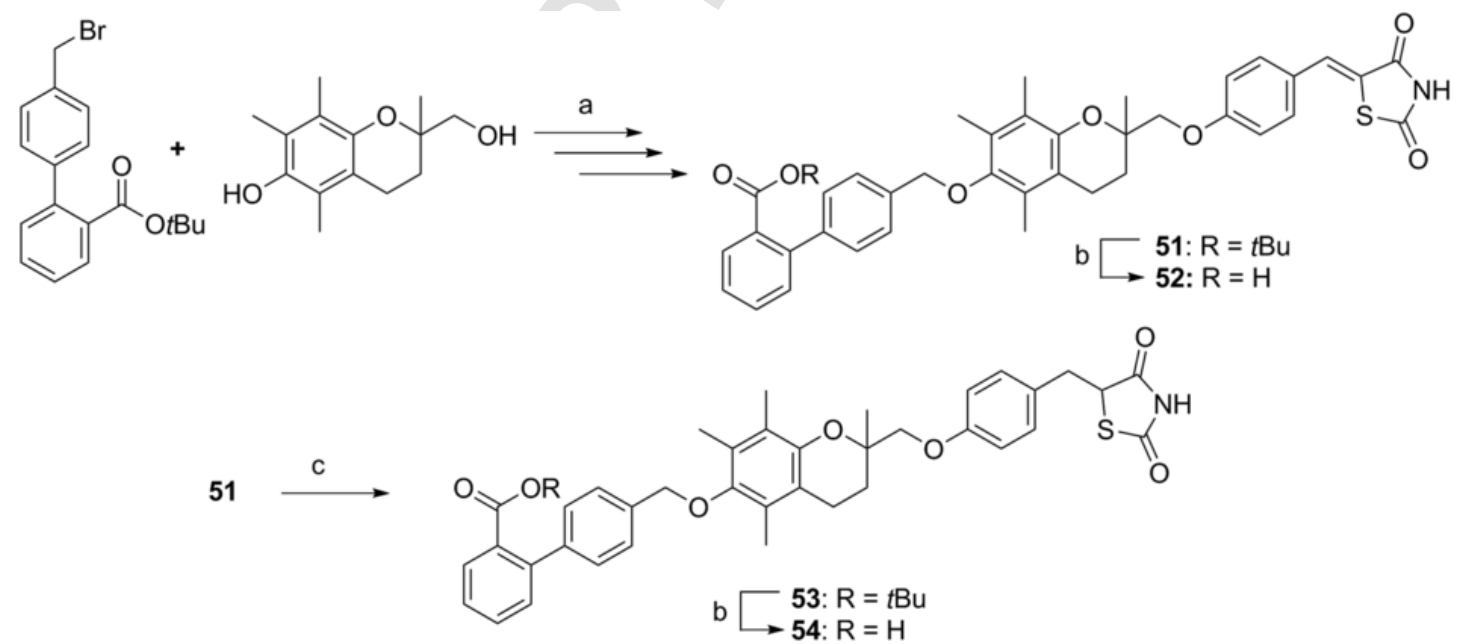

Scheme 8. Reagents and conditions: (a) See Ref. [37]; (b) $\mathrm{HCl}$; (c) $55 \mathrm{psi} \mathrm{H}_{2}, \mathrm{Pd} / \mathrm{C}$ 


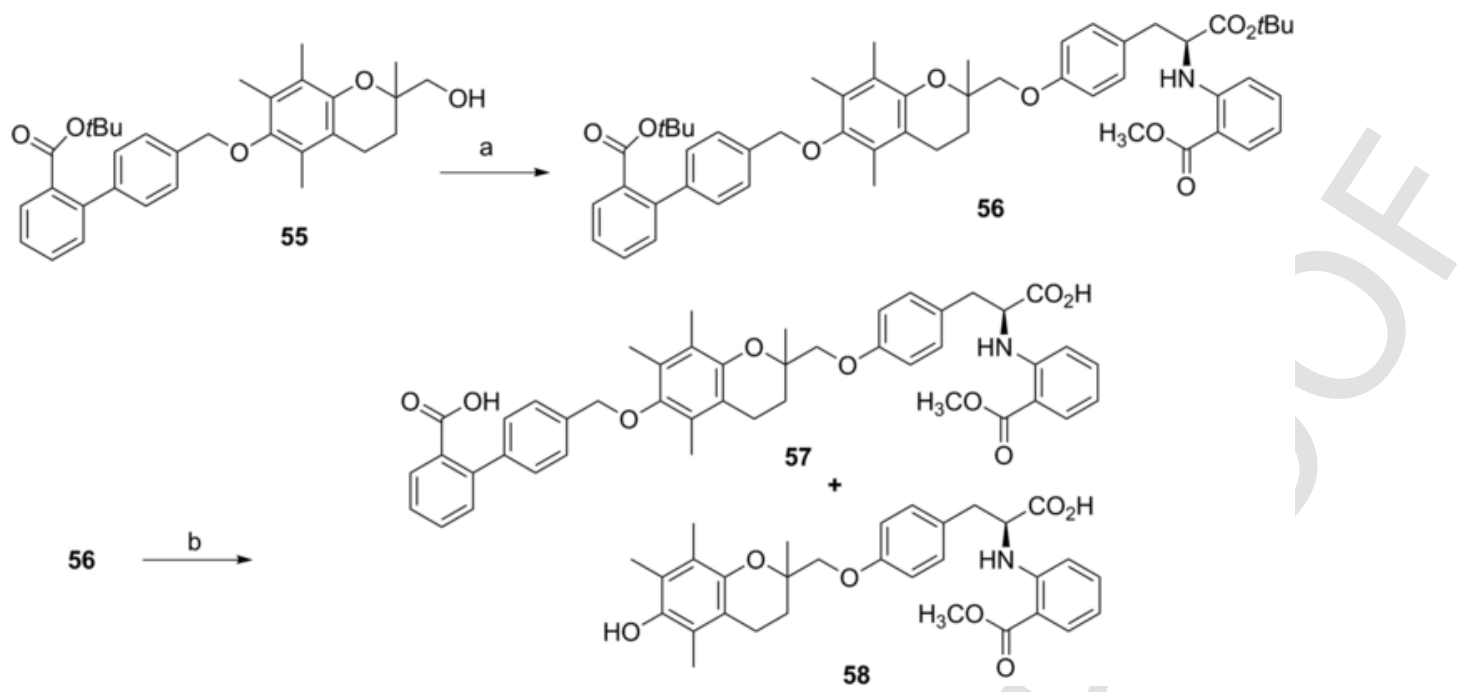

Scheme 9. Reagents and conditions: (a) 1) $\mathrm{Tf}_{2} \mathrm{O}$, Pyr., 2) 23, $\mathrm{K}_{2} \mathrm{CO}_{3}$; (b) TFA.

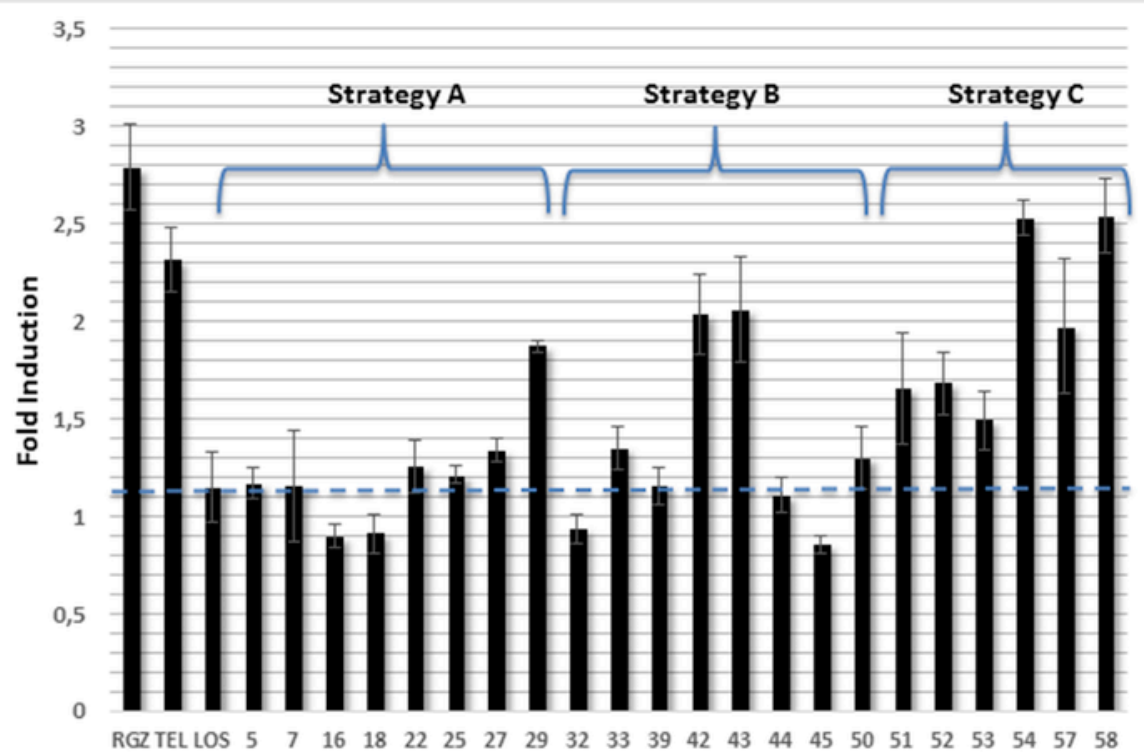

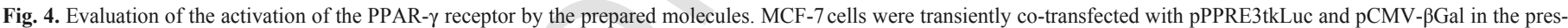

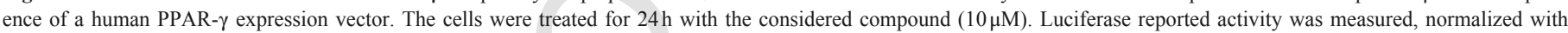

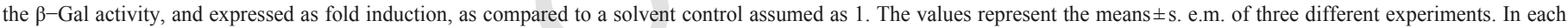
experiment, the activities of transfected plasmids were assayed in duplicate transfections.

Table 1

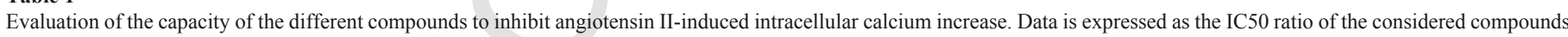
compared to losartan.

\begin{tabular}{|c|c|c|c|c|c|c|c|c|c|c|c|}
\hline Compound & losartan & 5 & 16 & 18 & 22 & 25 & 27 & 29 & 32 & 33 & 39 \\
\hline $\mathrm{IC}_{50}$ ratio & 1 & 6.3 & 1.1 & 0.4 & 3.2 & 3.8 & 11.1 & 43.2 & 3.4 & 5.0 & 16.2 \\
\hline sem & & 2.7 & 0.6 & 0.1 & 1.9 & 1.1 & 3.5 & 8.5 & 0.9 & 2.0 & 7.2 \\
\hline Strategy & $\mathrm{A}$ & $\mathrm{A}$ & A & $\mathrm{A}$ & $\mathrm{A}$ & A & A & A & B & B & B \\
\hline
\end{tabular}

with PPAR- $\gamma$. Fig. 5 represents the best docking structure (i.e., the one with the lowest binding energy) found with the AutoDock software for compound 54. Other representations of the best docking structures for the seven other compounds are reported in Supplementary Data (Figs. S2-S8). For each best docking structure represented in sticks, we also show the co-crystallized rosiglitazone position as lines for comparison purpose. Entrance, Arm I and Arm II surfaces of PPAR- $\gamma$, as defined by Zoete et al. [43] are colored in yellow, blue and salmon, respectively. Analysis with the LigPlot + software [44] for each ligand are reported in Fig. 6 for compound 54 and in Supple- 


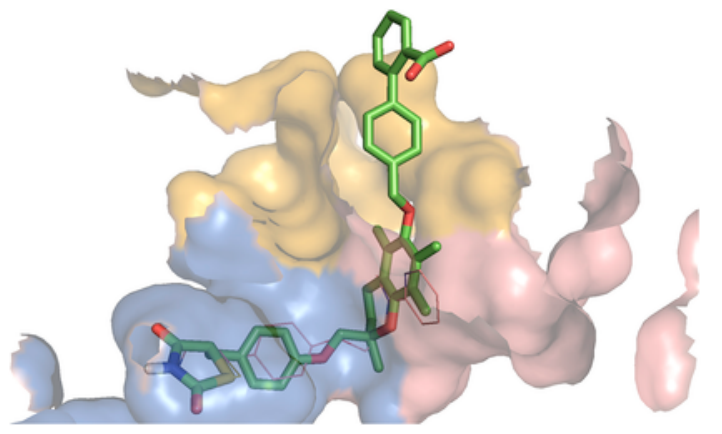

Fig. 5. Lowest binding free energy pose for compound $\mathbf{5 4}$ obtained with the AutoDock software. PPAR- $\gamma$ structure is extracted from PDB code 2 PRG. Molecule in sticks: compound 54; molecule in lines: co-crystallized rosiglitazone; blue, salmon and yellow surfaces: Arm I, Arm II and Entrance regions, respectively. (For interpretation of the references to color in this figure legend, the reader is referred to the Web version of this article.)

mentary Data (Figs. S9-S15) for the other compounds, respectively. A summary of all contacts found by LigPlot+, either hydrophobic or via hydrogen bonds, is also reported in Supplementary Data (Table S1).

First, we have verified that our docking procedure was able to retain the rosiglizatone pose found in the 2PRG crystallographic structure. In Fig. S2, the differences between the best AutoDock pose and the X-ray pose for rosiglitazone are small. Especially, the interactions of the thiazolidinedione ring with PPAR- $\gamma$ inside the Arm I pocket are very well conserved. Hydrogen bonds with Gln286, Ser289, His323 and Tyr473 are conserved in comparison with the experimental ligand-bound structure. Compound $\mathbf{5 4}$ is representative of our strategy C. It has two asymmetric centers, one on the thiazolidinedione (TZD) group, and the other on the chromane fragment. Rosiglitazone and other compounds containing TZD fragment bind to PPAR- $\gamma$ in the $(S)$ configuration (PDB codes 1FM6, 2PRG, 3CS8, 3DZY, 4EMA, $4 \mathrm{O} 8 \mathrm{~F}, 4 \mathrm{XLD}$, and $5 \mathrm{JI} 0)$. It has also already been experimentally reported that only the $(S)$ configuration of the TZD group is active in PPAR- $\gamma[45]$. Therefore, we have built and docked only the $(S)$ configuration of the TZD group for compound $\mathbf{5 4}$ as well as for rosiglitazone, compounds $\mathbf{4 2}, \mathbf{4 3}, \mathbf{4 4}$, and $\mathbf{4 5}$. In contrast, we have no information on a possible difference in activity between the $(R)$ and $(S)$ configurations of the chromane fragment of compound 54. Therefore, both stereoisomers have been built and docked in PPAR- $\gamma$. Our best AutoDock pose corresponds to the $(R)$ isomer for the chromane heterocycle. As shown in Fig. 5, the benzyl TZD fragment is inserted into Arm I in a conformation that is nearly identical to the crystallographic benzyl TZD fragment of rosiglitazone in 2PRG. The chromane superimposes also very nicely with the pyridyl group of rosiglitazone and the biphenyl fragment is mostly positioned in the Entrance region of PPAR- $\gamma$. The fact that compound $\mathbf{5 4}$ has a very good activity against PPAR- $\gamma$ can therefore be very well understood from the position of the different fragments of the molecule inside the binding pocket: compared to rosiglitazone, the benzyl TZD fragment can insert into Arm I without being perturbed by the presence of the biphenyl fragment and the "linker", here the chromane group, can very well replace the pyridyl group of rosiglitazone. Compounds 43 and $\mathbf{4 5}$ are representative of Strategy B. Compound 43 has a good activity against PPAR- $\gamma$ while $\mathbf{4 5}$ does not show any activity. At first sight, both molecules show similar docked poses (Figs. S3 and S4). As with rosiglitazone and compound 54, the benzyl TZD fragment inserts very well inside the Arm I pocket region. As the molecules are somewhat longer, the "linker", defined here as the ethyl triazole group, has a bended position compared to rosiglitazone.
For compound $\mathbf{4 5}$, the biphenyl fragment is placed towards the entrance. In the case of compound $\mathbf{4 3}$, the tertiobutyl ester is positioned in the Arm II region of PPAR- $\gamma$. The difference in activity between both compounds is difficult to explain from a quick visual inspection especially since compound 54, which is active towards PPAR- $\gamma$, seems to have a conformational binding pose very similar to that of the inactive compound $\mathbf{4 5}$. To further investigate the differences in binding modes between all the compounds, we have also performed a LigPlot + analysis of all the hydrophodic contacts and hydrogen bonds between each ligand and PPAR- $\gamma$. Fig. 6 shows the LigPlot + result for compound 54. In Supplementary Data, we have listed in Table S1 all the contacts between each ligand and the residues of PPAR- $\gamma$ for the lowest AutoDock binding free energies. From Table S1, the main difference between $\mathbf{4 5}$ and the other compounds, including rosiglitazone, is an interaction with Leu353 in the Arm II pocket that could be at the origin of the decrease in activity of PPAR- $\gamma$. This hydrophobic contact with Leu353 originates from a hydrogen bond between the biphenyl acid fragment with Ser342 that blocks the conformation, bends the compound towards Arm II and yields the contact with Leu353. A similar result is obtained when PPAR- $\gamma$ active compound 42 and PPAR- $\gamma$ inactive compound $\mathbf{4 4}$ are docked inside the target protein (see Supplementary Data). There again, a hydrogen bond exists between the biphenyl acid fragment of compound $\mathbf{4 4}$ and Ser342 of PPAR- $\gamma$ while the tertiobutyl ester of compound $\mathbf{4 2}$ does not. The difference of twisting between both molecules inside the PPAR- $\gamma$ binding pocket yields an interaction with Leu353 for compound 44 while compound $\mathbf{4 2}$ avoids this contact. The difference in activity between compounds 42 and 43 on one side and compounds 44 and 45 on the other side can therefore be explained by the fact that the presence of a tertiobutyl ester fragment prevents the making of a hydrogen bond with Ser342 and allows for a larger conformational freedom that skips an interaction with Leu353. Losartan and compound $\mathbf{2 9}$ are representative of Strategy A. The former is active on $\mathrm{AT}_{1}$ and not on PPAR- $\gamma$ while the latter shows activity for both targets and therefore shows some dual properties. Compared to rosiglitazone and compounds $\mathbf{5 4}$, and 42 to 45 , the lowest binding free energy poses of losartan and 29 are quite different (Figs. S7 and S8, respectively). This is mostly due to the fact that none of these two compounds bear a TZD fragment. Losartan shows no hydrogen bond with the Arm I pocket and especially with Helix 3, a. k.a. H3 (Gln286 and Ser289), H5 (His323) and H12 (Tyr473) (Table S1). Only one hydrogen bond with Cys285 is observed. Similarly, compound $\mathbf{2 9}$ has not a lot of interaction with Arm I. However, the phenyl ring that bears the tetrazole fragment of 29 is located at the same position than the phenyl ring of rosiglitazone. Compared to losartan, the position of this phenyl ring yields a deeper insertion into the PPAR- $\gamma$ binding pocket. This can be explained by the fact that $\mathbf{2 9}$ holds a very long fatty chain, fatter than the biphenyl fragment of losartan. This long fatty fragment naturally positions itself in the Arm II and Entrance regions that contain many hydrophobic residues. In terms of hydrophobic contacts, LigPlot + identifies for compound 29: Ile281, Ile341, Met348, and Met364 for the Arm II pocket and Leu228, Arg288, Ala292, Leu330, Leu333, Leu340, and Ser342 for the Entrance region (Table S1). These numerous hydrophobic interactions "push" the biphenyl fragment of compound 29 deeper into Arm I. The polar tetrazole fragment could better interact with Arm I and Helices 3, 5 and 12, as in the rosiglitazone case, if it was located in a para instead of an ortho position. This would probably reinforce PPAR- $\gamma$ activity but, at the same time, $\mathrm{AT}_{1}$ activity would be abrogated since para derivatives proved to be inactive [42]. Thus, our docking simulations seems to show that the PPAR- $\gamma$ activity of compound 29 is mostly due to two factors: the hydrophobic contacts of 


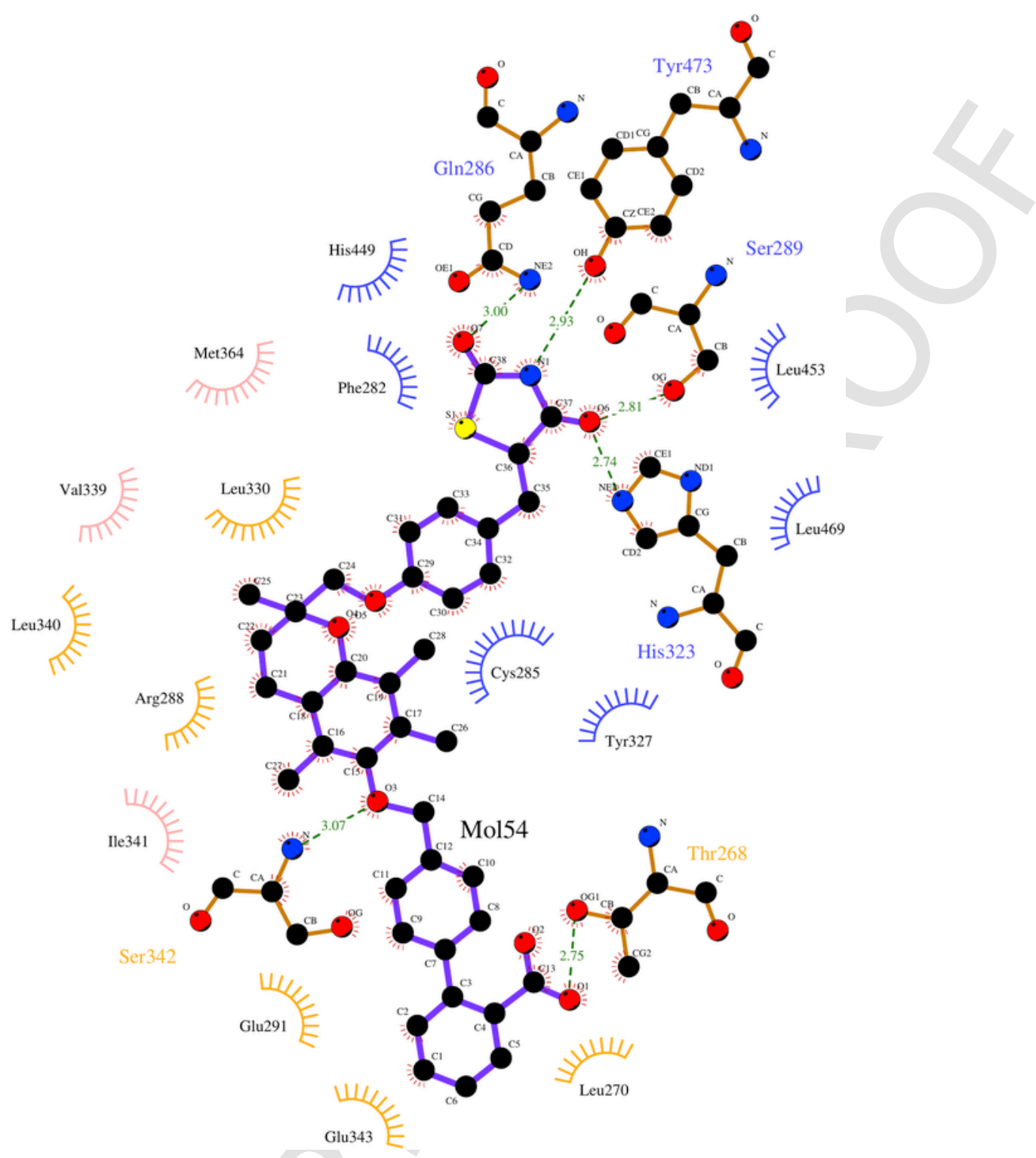

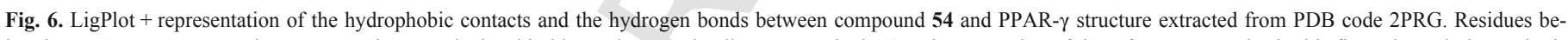

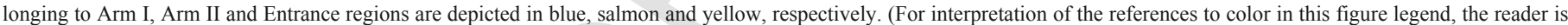
referred to the Web version of this article.)

the fatty chain with the Arm II and Entrance regions of PPAR- $\gamma$, and the adequate positioning of the phenyl ring bearing the tetrazole fragment inside the Arm I pocket.

Altogether, Strategy A afforded compound 18 which was more potent as an ARB than losartan, but was completely PPAR- $\gamma$ inactive. Slightly PPAR- $\gamma$ active molecules were obtained (22, 25, and 27) which exhibited fair activity on $\mathrm{AT}_{1}$. By far is compound 29 the most active PPAR- $\gamma$ agonist in this series. We considered that increasing the lipophilic character of losartan could result in an increased activity, and the docking studies confirmed that the numerous hydrophobic interactions established with the receptor are linked with its potency. In addition, compound $\mathbf{2 9}$ proved to be active as an ARB in the first sorting of the compounds, although it later showed to have the highest $\mathrm{IC}_{50}$. Thus, 29 can be regarded as a compound possessing dual activity. Strategy B afforded 33, which is a slightly PPAR- $\gamma$ active molecule, but showing fair $\mathrm{AT}_{1}$ activity. Besides, compounds $\mathbf{4 2}$ and $\mathbf{4 3}$ were highly active on PPAR- $\gamma$, but totally inactive on $\mathrm{AT}_{1}$ receptor.
Finally, Strategy $\mathrm{C}$ afforded the most potent PPAR- $\gamma$ agonists, but none of them behaved as an ARB. It is well-known that many PPAR- $\gamma$ activating compounds exhibit anti-proliferative activity [46-50]. Thus, it could be interesting to determine if our dual molecules also display anti-proliferative activity. We already reported [37] the anti-proliferative activities of unsaturated synthetic intermediates $\mathbf{3 0}$, 31, 40, 41, 51, 52 and of unsaturated analogues of compounds 32, 33, 44, and 45. Mainly, the anti-proliferative activity was observed with compounds bearing $t$-butyl protecting groups. Yet, the present compounds intended to exhibit dual PPAR- $\gamma / \mathrm{AT}_{1}$ activity are devoid of this group and therefore should not hold significant anti-proliferative activity. In addition, in order to get dual molecules in the present work, we have reduced the unsaturation next to the TZD ring. We showed [51] that reducing the double bond of benzilidene-2,4-thizolidinediones decreases their anti-proliferative activity. As a result, our series of new compounds might not exhibit potent anti-proliferative activity; nevertheless, systematic toxicity studies on both cancerous 
and non-cancerous cells of all our PPAR- $\gamma$ active molecules will be investigated. As a perspective, we will also study both PPAR- $\gamma$ and $\mathrm{AT}_{1}$ activities in vivo. As a preliminary result, we already evaluated [52] the antihypertensive activity of the synthetically accessible compound 5 on rats (Fig. 7). After intravenous administration, this compound blunted Angiotensin II-induced hypertension with the same intensity than losartan, thus validating the concept.

\section{Conclusion}

In the frame of the search for new treatments against metabolic syndrome, we designed new molecules with putative dual activity by merging ARB and PPAR- $\gamma$ agonist pharmacophores in the same structure. Several compounds were synthesized, following three different strategies. Their ability to interact with PPAR- $\gamma$ receptor was performed using MCF-7 cells transfected with a pPPRE3tk-luc reporter, with rosiglitazone as a positive control. Their activity as $\mathrm{AT}_{1}$ receptor blockers was evaluated by a fluorescence test visualizing inhibition of Angiotensin II-mediated intracellular calcium release in rat aortic smooth muscle cells. Strategy $\mathrm{C}$ afforded very active PPAR- $\gamma$ agonists (such as $\mathbf{5 4}$ and 58), but none could antagonize $\mathrm{AT}_{1}$ receptor. Strategy $\mathrm{B}$ gave fair $\mathrm{AT}_{1}$ receptor antagonists $(\mathbf{3 2}, \mathbf{3 3}$, and 39) which were mainly devoid of PPAR- $\gamma$ activity, and on the other hand it gave compounds $\mathbf{4 2}$ and $\mathbf{4 4}$ which were potent PPAR- $\gamma$ activators without any $\mathrm{AT}_{1}$ activity. Finally, strategy A afforded many molecules with fair to good $\mathrm{AT}_{1}$ blocking ability among which molecule 29 also exhibited good PPAR- $\gamma$ activity. Molecular docking revealed that hydrophobic interactions of its dodecyl chain with the Arm II region of the receptor are significant. One can note that the losartan template is quite tolerant towards chemical modification on its primary alcohol function, since almost all the molecules derived from strategy A displayed an $\mathrm{AT}_{1}$ blocking ability. This particular approach could be further explored in order to obtain new dual molecules. In addition, in vitro anti-proliferative activity investigations and in vivo antidiabetic and antihypertensive potency evaluations are envisioned in our team. Among them, a preliminary assay showed potent anti-hypertensive effect of compound $\mathbf{5}$ on rats.

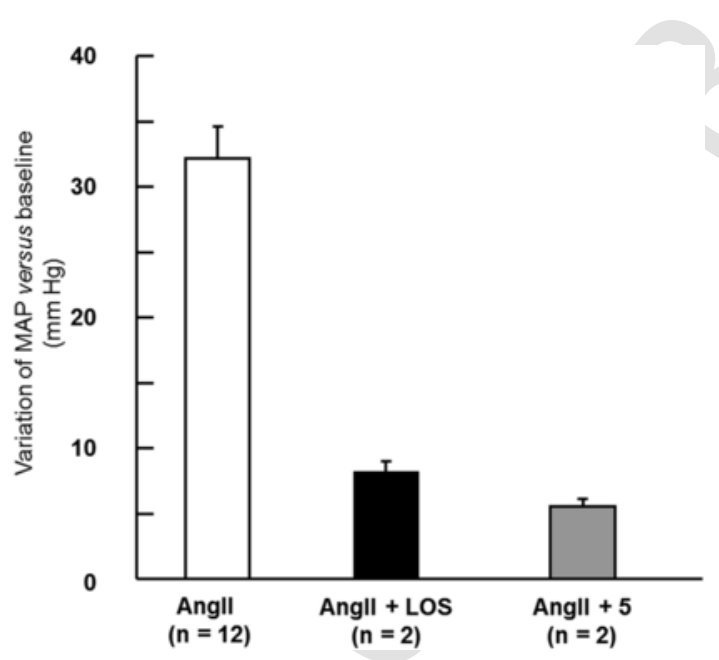

Fig. 7. Variation of mean arterial pressure (MAP in $\mathrm{mm} \mathrm{Hg}, \mathrm{m} \pm \mathrm{sem}$ ) in adult male Wistar rats induced by i. v. bolus of Angiotensin II (AngII, 10-10 mol $/ \mathrm{kg}$ ) in the absence of pre-treatment (empty bars) or in the presence of Losartan (LOS, black bars) or compound 5 (dark grey bars) at a dose of $6 \cdot 10^{-5} \mathrm{~mol} / \mathrm{kg}$.

\section{Experimental protocols}

\subsection{Chemistry}

\subsubsection{General methods}

Solvents and liquid reagents were purified and dried according to recommended procedures. Chemical reagents were purchased from Sigma-Aldrich, Alfa Aesar or TCI Europe and were used as received. Microwave irradiations were performed using a CEM Discover apparatus. Analytical thin-layer chromatography was performed with silica gel 60 F254, $0.25 \mathrm{~mm}$ pre-coated TLC plates (Merck). Compounds were visualized using UV light $(254 \mathrm{~nm})$ and a solution of cerium sulfate tetrahydrate and phosphomolybdic acid in $10 \%$ aqueous sulfuric acid as developing agent. Column chromatographies were performed using a Grace Reveleris ${ }^{\circledR}$ apparatus using $40-50 \mu \mathrm{M}$ silica gel or $\mathrm{C} 18$ cartridges. NMR spectra were recorded at $303 \mathrm{~K}$ on a Bruker DPX250 (250 MHz for ${ }^{1} \mathrm{H}$ and $62.9 \mathrm{MHz}$ for $\left.{ }^{13} \mathrm{C}\right)$ spectrometer or on a Bruker DRX400 (400 MHz for ${ }^{1} \mathrm{H}$ and $100.6 \mathrm{MHz}$ for ${ }^{13} \mathrm{C}$ ) spectrometer. The chemical shifts are reported in $\mathrm{ppm}(\delta)$ relative to residual solvent peak [53]. Mass spectra (MS) of the majority of the compounds were recorded on a micrOTOFq (Bruker) ESI/QqTOF spectrometer. Mass spectra of compounds 54, 56, 57, and $\mathbf{5 8}$ were recorded on a VG-Platform Micromass-Waters (ESI+/quad) spectrometer. Melting points (M.p.) were determined with a Kofler bench and are uncorrected. FTIR spectra were recorded on a Perkin-Elmer spectrum 1000 spectrophotometer using a thin film deposition on $\mathrm{NaCl}$ window or $\mathrm{KBr}$ pellets. Elemental analyses were performed using a Thermofinnigan Flash EA 1112 apparatus.

\subsubsection{Calculation of the $\operatorname{cog} P$ of losartan and derivatives}

The clogP values (octanol/water partition coefficients) were calculated in order to estimate the lipophilicity character of three molecules: losartan, losartan-aldehyde and dodecyl-losartan 29. These calculations were achieved using MarvinSketch software (Marvin 16.8.22.0, 2016, ChemAxon (https://chemaxon.com).

\subsubsection{Chemical synthesis of strategy a molecules}

6.1.3.1. (2-Butyl-5-chloro-3-[2'-(2-trityl-2H-tetrazol-5-yl)-biphenyl4-ylmethyl]-3H-imidazol-4-yl)methanol (1)

To a solution of losartan potassium salt $(2.50 \mathrm{~g}, 5.42 \mathrm{mmol})$ in anhydrous DMF $(60 \mathrm{~mL})$ under argon were added triethylamine $(0.83 \mathrm{~mL}, 5.96 \mathrm{mmol})$ and trityl chloride $(1.66 \mathrm{~g}, 5.96 \mathrm{mmol})$. The mixture was stirred for $18 \mathrm{~h}$ at room temperature. To the solution was added EtOAc $(100 \mathrm{~mL})$ and the mixture was washed with water $(4 \times 50 \mathrm{~mL})$. The organic phase was dried $\left(\mathrm{MgSO}_{4}\right)$ and the solvent was removed under vacuum to give a residue which was purified by column chromatography (eluent: hexane/EtOAc, 90:10) to give $3.27 \mathrm{~g}$ ( $4.90 \mathrm{mmol}, 91 \%$ yield) of white solid. M. p. $106-108^{\circ} \mathrm{C}$. IR (film) v $\left(\mathrm{cm}^{-1}\right): 3223,2955,2866,1732,1572,1493,1445,1250,1024,1001$, $746,696 .{ }^{1} \mathrm{H}$ NMR $\left(250 \mathrm{MHz}, \mathrm{CDCl}_{3}\right): \delta 0.86\left(\mathrm{t}, J=7.5 \mathrm{~Hz}, 3 \mathrm{H}, \mathrm{CH}_{3}\right)$, 1.23-1.34 (m, 2H, $\left.\mathrm{CH}_{2}\right), 1.58-1.71\left(\mathrm{~m}, 2 \mathrm{H}, \mathrm{CH}_{2}\right), 2.46-2.53(\mathrm{~m}, 2 \mathrm{H}$, $\left.\mathrm{CH}_{2}\right), 4.31\left(\mathrm{~d}, \mathrm{~J}=5.0 \mathrm{~Hz}, 2 \mathrm{H}, \mathrm{CH}_{2} \mathrm{OH}\right), 5.09\left(\mathrm{~s}, 2 \mathrm{H}, \mathrm{CH}_{2} \mathrm{~N}\right), 6.75(\mathrm{~d}$, $\left.J=7.8 \mathrm{~Hz}, 2 \mathrm{H}, \mathrm{H}_{\text {arom }}\right), 6.89-6.95\left(\mathrm{~m}, 6 \mathrm{H}, \mathrm{H}_{\text {arom }}\right), 7.12(\mathrm{~d}, J=7.8 \mathrm{~Hz}$, $\left.2 \mathrm{H}, \mathrm{H}_{\text {arom }}\right), 7.23-7.36\left(\mathrm{~m}, 10 \mathrm{H}, \mathrm{H}_{\text {arom }}\right), 7.43-7.53\left(\mathrm{~m}, 2 \mathrm{H}, \mathrm{H}_{\text {arom }}\right.$ ), 7.93-7.96 (m, 1H, $\left.\mathrm{H}_{\text {arom }}\right) .{ }^{13} \mathrm{C} \mathrm{NMR}\left(62.9 \mathrm{MHz}, \mathrm{CDCl}_{3}\right): \delta 13.9\left(\mathrm{CH}_{3}\right)$, $22.59\left(\mathrm{CH}_{2}\right), 26.9\left(\mathrm{CH}_{2}\right), 29.9\left(\mathrm{CH}_{2}\right), 47.3\left(\mathrm{CH}_{2}\right), 53.3\left(\mathrm{CH}_{2}\right), 83.0$, 124.8, $125.4\left(\mathrm{CH}_{\text {arom }}\right), 126.4,127.8\left(\mathrm{CH}_{\text {arom }}\right), 127.9\left(\mathrm{CH}_{\text {arom }}\right), 128.4$ $\left(\mathrm{CH}_{\text {arom }}\right), 130.0\left(\mathrm{CH}_{\text {arom }}\right), 130.1\left(\mathrm{CH}_{\text {arom }}\right), 130.3\left(\mathrm{CH}_{\text {arom }}\right), 130.4$ $\left(\mathrm{CH}_{\text {arom }}\right), 130.9\left(\mathrm{CH}_{\text {arom }}\right), 134.7,141.1,141.5,148.7,164.0$. ESI-MS (pos. mode): $m / z=665.33\left([\mathrm{M}+\mathrm{H}]^{+},{ }^{35} \mathrm{Cl}\right), 667.24\left([\mathrm{M}+\mathrm{H}]+{ }^{+},{ }^{37} \mathrm{Cl}\right)$, $687.23\left([\mathrm{M}+\mathrm{Na}]^{+}\right.$, 
${ }^{35} \mathrm{Cl}$ ). Anal. Calcd for $\mathrm{C}_{41} \mathrm{H}_{37} \mathrm{ClN}_{6} \mathrm{O}$ (665.22): C, 74.03; H, 5.61; N, 12.63. Found: C, 73.76; H, 5.69; N, 12.53 .

6.1.3.2. 4-\{2-Butyl-5-chloro-3-[2'-(2-trityl-2H-tetrazol-5-yl)biphenyl4-ylmethyl]-3H-imidazol-4-ylmethoxy\} benzaldehyde (2)

To a solution of $\mathbf{1}(1.90 \mathrm{~g}, 2.86 \mathrm{mmol})$ in anhydrous THF $(35 \mathrm{~mL})$ under argon were added triphenylphosphine $(900 \mathrm{mg}, 3.43 \mathrm{mmol})$ and freshly recrystallized 4-hydroxybenzaldehyde ( $385 \mathrm{mg}, 3.15 \mathrm{mmol})$. The solution is cooled in an ice bath, and then a solution of DEAD $(0.54 \mathrm{~mL}, 3.43 \mathrm{mmol})$ in anhydrous THF $(14 \mathrm{~mL})$ is added dropwise. The mixture is stirred at room temperature for $18 \mathrm{~h}$. The solvent is removed under vacuum, and the residue is purified by column chromatography (eluent: hexane/EtOAc, 70:30) to give $750 \mathrm{mg}$ $(0.97 \mathrm{mmol}, 35 \%$ yield $)$ of white solid. M. p. $103-105^{\circ} \mathrm{C}$. IR (film) v $\left(\mathrm{cm}^{-1}\right): 3378,3060,2954,2926,2862,1692,1600,1578,1253$, $1159,698 .{ }^{1} \mathrm{H}$ NMR $\left(250 \mathrm{MHz}, \mathrm{CDCl}_{3}\right): \delta 0.87\left(\mathrm{t}, J=7.4 \mathrm{~Hz}, 3 \mathrm{H}, \mathrm{CH}_{3}\right)$, $1.23-1.38\left(\mathrm{~m}, 2 \mathrm{H}, \mathrm{CH}_{2}\right), 1.62-1.74\left(\mathrm{~m}, 2 \mathrm{H}, \mathrm{CH}_{2}\right), 2.49-2.56(\mathrm{~m}, 2 \mathrm{H}$, $\left.\mathrm{CH}_{2}\right), 4.77\left(\mathrm{~s}, 2 \mathrm{H}, \mathrm{CH}_{2} \mathrm{O}\right), 5.07\left(\mathrm{~s}, 2 \mathrm{H}, \mathrm{CH}_{2} \mathrm{~N}\right), 6.73(\mathrm{~d}, J=8.3 \mathrm{~Hz}, 2 \mathrm{H}$, $\left.\mathrm{H}_{\text {arom }}\right), 6.86\left(\mathrm{~d}, J=8.3 \mathrm{~Hz}, 2 \mathrm{H}, \mathrm{H}_{\text {arom }}\right), 6.92-6.95\left(\mathrm{~m}, 6 \mathrm{H}, \mathrm{H}_{\text {arom }}\right), 7.10$ $\left(\mathrm{d}, J=8.3 \mathrm{~Hz}, 2 \mathrm{H}, \mathrm{H}_{\text {arom }}\right), 7.20-7.35\left(\mathrm{~m}, 10 \mathrm{H}, \mathrm{H}_{\text {arom }}\right), 7.44-7.54(\mathrm{~m}$, $\left.2 \mathrm{H}, \mathrm{H}_{\text {arom }}\right), 7.74\left(\mathrm{~d}, J=8.3 \mathrm{~Hz}, 2 \mathrm{H}, \mathrm{H}_{\text {arom }}\right), 7.92(\mathrm{dd}, J=1.7,6.9 \mathrm{~Hz}$, $\left.1 \mathrm{H}, \mathrm{H}_{\text {arom }}\right), 9.84(\mathrm{~s}, 1 \mathrm{H}, \mathrm{CHO}) .{ }^{13} \mathrm{C}$ NMR $\left(62.9 \mathrm{MHz}, \mathrm{CDCl}_{3}\right): \delta$ $13.9\left(\mathrm{CH}_{3}\right), 22.6\left(\mathrm{CH}_{2}\right), 26.9\left(\mathrm{CH}_{2}\right), 29.8\left(\mathrm{CH}_{2}\right), 47.6\left(\mathrm{CH}_{2} \mathrm{~N}\right), 59.0$ $\left(\mathrm{CH}_{2} \mathrm{O}\right), 83.0,115.1\left(2 \times \mathrm{CH}_{\text {arom }}\right), 120.3,125.4\left(2 \times \mathrm{CH}_{\text {arom }}\right), 126.4$, $127.8\left(6 \times \mathrm{CH}_{\text {arom }} \mathrm{Tr}\right), 128.0,128.5\left(3 \times \mathrm{CH}_{\text {arom }} \mathrm{Tr}\right), 129.8,130.1$ $\left(2 \times \mathrm{CH}_{\text {arom }}\right), 130.2,130.3\left(6 \times \mathrm{CH}_{\text {arom }} \mathrm{Tr}\right), 130.5,130.6,130.8,132.1$ $\left(2 \times \mathrm{CH}_{\text {arom }}\right), 134.2,141.3,141.5\left(3 \times \mathrm{C}_{\text {arom }} \mathrm{Tr}\right), 149.7,150.2,162.7$, 164.1, 190.9 (CHO). ESI-MS (pos. mode): $m / z=769.31\left([\mathrm{M}+\mathrm{H}]^{+}\right.$, ${ }^{35} \mathrm{Cl}$ ). Anal. Calcd for $\mathrm{C}_{48} \mathrm{H}_{41} \mathrm{ClN}_{6} \mathrm{O}_{2}$ (769.33): C, 74.94; $\mathrm{H}, 5.37 ; \mathrm{N}$, 10.92. Found: C, 74.95; H, 5.43; N, 10.92 .

6.1.3.3. (Z)-5-(4-\{2-Butyl-5-chloro-3-[2'-(2-trityl-2H-tetrazol-5yl)biphenyl-4-ylmethyl]-3H-imidazol-4-

ylmethoxy\} benzylidene)thiazolidine-2,4-dione (3)

To a solution of $2(750 \mathrm{mg}, 0.97 \mathrm{mmol})$ in anhydrous toluene anhydre $(35 \mathrm{~mL})$ under argon were added thiazolidine-2,4-dione $(228 \mathrm{mg}$, $1.95 \mathrm{mmol})$ and piperidine $(19 \mu \mathrm{L}, 0.19 \mathrm{mmol})$. The mixture was stirred at reflux for $18 \mathrm{~h}$. The solvent was removed under vacuum, the residue was dissolved in EtOAc $(70 \mathrm{~mL})$, and the solution was washed with water $(3 \times 30 \mathrm{~mL})$. The organic phase was dried $\left(\mathrm{MgSO}_{4}\right)$, and the solvent was removed. The residue was purified by column chromatography (eluent: hexane/EtOAc, 80/20) to give $565 \mathrm{mg}(0.65 \mathrm{mmol}, 67 \%$ yield) of yellow solid. M. p. $230-232^{\circ} \mathrm{C}$. IR (film) $v\left(\mathrm{~cm}^{-1}\right): 3435$, 3056, 2956, 2924, 1740, 1701, 1592, 1508, 1249, 1176, 698. ${ }^{1} \mathrm{H}$ NMR $\left(250 \mathrm{MHz}, \mathrm{CDCl}_{3}\right): \delta 0.86\left(\mathrm{t}, J=7.4 \mathrm{~Hz}, 3 \mathrm{H}, \mathrm{CH}_{3}\right), 1.24-1.38(\mathrm{~m}, 2 \mathrm{H}$, $\left.\mathrm{CH}_{2}\right), 1.61-1.74\left(\mathrm{~m}, 2 \mathrm{H}, \mathrm{CH}_{2}\right), 2.51-2.57\left(\mathrm{~m}, 2 \mathrm{H}, \mathrm{CH}_{2}\right), 4.75(\mathrm{~s}, 2 \mathrm{H}$, $\left.\mathrm{CH}_{2} \mathrm{O}\right), 5.07\left(\mathrm{~s}, 2 \mathrm{H}, \mathrm{CH}_{2} \mathrm{~N}\right), 6.73\left(\mathrm{~d}, J=8.0 \mathrm{~Hz}, 2 \mathrm{H}, \mathrm{H}_{\text {arom }}\right), 6.83$ (d, $\left.J=8.8 \mathrm{~Hz}, 2 \mathrm{H}, \mathrm{H}_{\text {arom }}\right), 6.93-6.96\left(\mathrm{~m}, 6 \mathrm{H}, \mathrm{H}_{\text {arom }}\right), 7.10(\mathrm{~d}, J=8.0 \mathrm{~Hz}$, $\left.2 \mathrm{H}, \mathrm{H}_{\text {arom }}\right), 7.21-7.36\left(\mathrm{~m}, 10 \mathrm{H}, \mathrm{H}_{\text {arom }}\right), 7.44-7.55\left(\mathrm{~m}, 2 \mathrm{H}, \mathrm{H}_{\text {arom }}\right)$, $7.75(\mathrm{~s}, 1 \mathrm{H}, \mathrm{CH}=), 7.92\left(\mathrm{dd}, J=1.8,6.9 \mathrm{~Hz}, 1 \mathrm{H}, \mathrm{H}_{\text {arom }}\right), 9.97-9.50$ (br s, $1 \mathrm{H}, \mathrm{NH}) .{ }^{13} \mathrm{C} \mathrm{NMR}\left(62.9 \mathrm{MHz}, \mathrm{CDCl}_{3}\right): \delta 13.9\left(\mathrm{CH}_{3}\right), 22.5$ $\left(\mathrm{CH}_{2}\right), 26.9\left(\mathrm{CH}_{2}\right), 29.8\left(\mathrm{CH}_{2}\right), 47.6\left(\mathrm{CH}_{2} \mathrm{~N}\right), 58.9\left(\mathrm{CH}_{2} \mathrm{O}\right), 83.0$, $115.6\left(2 \times \mathrm{CH}_{\text {arom }}\right), 120.0,120.5,125.4\left(2 \times \mathrm{CH}_{\text {arom }}\right), 126.3,126.4$, $127.8\left(6 \times \mathrm{CH}_{\text {arom }}\right), \quad 128.0, \quad 128.5 \quad\left(3 \times \mathrm{CH}_{\text {arom }}\right), \quad 129.6, \quad 130.0$ $\left(2 \times \mathrm{CH}_{\text {arom }}\right), \quad 130.2, \quad 130.3 \quad\left(6 \times \mathrm{CH}_{\text {arom }}\right), \quad 130.5, \quad 130.8, \quad 132.4$ $\left(2 \times \mathrm{CH}_{\text {arom }}\right), 134.0,134.2,141.2,141.3,141.4\left(3 \times \mathrm{C}_{\text {arom }}\right), 149.7$, 159.7, 164.1, $166.9(\mathrm{C}=\mathrm{O}), 167.3(\mathrm{C}=\mathrm{O})$. ESI-MS (neg. mode): $\left.m / z=866.27([\mathrm{M}-\mathrm{H}]]^{-},{ }^{35} \mathrm{Cl}\right)$. Anal. Calcd for $\mathrm{C}_{51} \mathrm{H}_{42} \mathrm{ClN}_{7} \mathrm{O}_{3} \mathrm{~S}, \mathrm{H}_{2} \mathrm{O}$ (886.46): C, 70.53; H, 4.87; N, 11.29. Found: C, 70.15; H, 4.56; N, 11.03.
6.1.3.4. 5-(4-\{2-Butyl-5-chloro-3-[2'-(2H-tetrazol-5-yl)biphenyl-4ylmethyl]-3H-imidazol-4-ylmethoxy\}benzyl)thiazolidine-2,4-dione (4)

In a Parr flask was introduced $\mathrm{Pd} / \mathrm{C}(120 \mathrm{mg}, 10 \% \mathrm{Pd})$, then a solution of $3(120 \mathrm{mg}, 0.14 \mathrm{mmol})$ in dioxane $(15 \mathrm{~mL})$ was added. The suspension was shaken in the presence of $\mathrm{H}_{2}(70 \mathrm{psi})$ for 4 days at room temperature, filtered on celite ${ }^{\circledR}$, and the solvent was removed under vacuum. The residue was dissolved in THF and a $2 \mathrm{~N}$ aqueous $\mathrm{HCl}$ solution $(3 \mathrm{~mL})$ was added. The mixture was stirred 4 hat room temperature and the solvent was removed. The residue was purified by column chromatography (eluent: $\mathrm{CH}_{2} \mathrm{Cl}_{2} / \mathrm{MeOH}, 90 / 10$ ) to give $53 \mathrm{mg}$ ( $0.08 \mathrm{mmol}, 60 \%$ yield) of yellow solid. M. p. $144-146^{\circ} \mathrm{C}$. IR $(\mathrm{KBr}) \mathrm{v}$ $\left(\mathrm{cm}^{-1}\right): 3423,2958,2930,1753,1701,1609,1509,1460,1253,1178$, $1153,1005 .{ }^{1} \mathrm{H}$ NMR $\left(250 \mathrm{MHz}, \mathrm{DMSO}-d_{6}\right): \delta 0.80(\mathrm{t}, J=7.3 \mathrm{~Hz}, 3 \mathrm{H}$, $\mathrm{CH}_{3}$ ), 1.17-1.32 (m, 2H, $\left.\mathrm{CH}_{2}\right), 1.42-1.54\left(\mathrm{~m}, 2 \mathrm{H}, \mathrm{CH}_{2}\right), 3.05$ (dd, A part of an ABX system, $\left.J=9.1,14.1 \mathrm{~Hz}, 1 \mathrm{H}, \mathrm{PhCH}_{2}\right), 4.86$ (dd, $\mathrm{X}$ part of an ABX system, $J=4.4,9.1 \mathrm{~Hz}, 1 \mathrm{H}, \mathrm{CH}), 4.93(\mathrm{~s}, 2 \mathrm{H}$, $\left.\mathrm{CH}_{2} \mathrm{O}\right), 5.22\left(\mathrm{~s}, 2 \mathrm{H}, \mathrm{CH}_{2} \mathrm{~N}\right), 6.82\left(\mathrm{~d}, \mathrm{~J}=8.6 \mathrm{~Hz}, 2 \mathrm{H}, \mathrm{H}_{\text {arom }}\right), 6.97-7.08$ $\left(\mathrm{m}, 4 \mathrm{H}, \mathrm{H}_{\text {arom }}\right), 7.14\left(\mathrm{~d}, J=8.6 \mathrm{~Hz}, 2 \mathrm{H}, \mathrm{H}_{\text {arom }}\right), 7.49-7.74(\mathrm{~m}, 4 \mathrm{H}$, $\left.\mathrm{H}_{\text {arom }}\right) .{ }^{13} \mathrm{C}$ NMR $\left(62.9 \mathrm{MHz}, \mathrm{DMSO}-d_{6}\right): \delta 13.6\left(\mathrm{CH}_{3}\right), 21.6\left(\mathrm{CH}_{2}\right)$, $25.8\left(\mathrm{CH}_{2}\right), 28.8\left(\mathrm{CH}_{2}\right), 36.3\left(\mathrm{CH}_{2}\right), 46.7\left(\mathrm{CH}_{2} \mathrm{~N}\right), 52.9(\mathrm{CH}), 57.9$ $\left(\mathrm{CH}_{2} \mathrm{O}\right), 114.6\left(2 \times \mathrm{CH}_{\text {arom }}\right), 121.3,123.7,126.3\left(2 \times \mathrm{CH}_{\text {arom }}\right), 127.6$, $127.8,129.0\left(2 \times \mathrm{CH}_{\text {arom }}\right), 129.3,130.3\left(2 \times \mathrm{CH}_{\text {arom }}\right), 130.5,130.9$, $135.8,138.5,141.0,148.6,156.6,166.1,171.6(\mathrm{C}=\mathrm{O}), 175.6(\mathrm{C}=$ O). ESI-MS (neg. mode): $\left.m / z=626.17([\mathrm{M}-\mathrm{H}]]^{-},{ }^{35} \mathrm{Cl}\right)$. Anal. Calcd for $\mathrm{C}_{32} \mathrm{H}_{30} \mathrm{ClN}_{7} \mathrm{O}_{3} \mathrm{~S}, \mathrm{H}_{2} \mathrm{O}$ (646.15): C, 59.48; $\mathrm{H}, 4.99 ; \mathrm{N}, 15.17$. Found: C, 59.83; H, 4.66; N, 15.07.

6.1.3.5. 5-(4-\{2-Butyl-5-chloro-3-[2'-(2H-tetrazol-5-yl)biphenyl-4ylmethyl]-3H-imidazol-4-ylmethoxy\}benzyl)thiazolidine-2,4-dione potassium salt (5)

A solution of $4(98 \mathrm{mg}, 0.16 \mathrm{mmol})$ in EtOAc $(30 \mathrm{~mL})$ was extracted with a $62 \mathrm{mM}$ aqueous $\mathrm{KOH}$ solution $(4 \times 5 \mathrm{~mL})$. The aqueous phases were gathered and evaporated. The residue was purified by reversed-phase column chromatography (eluent: $\mathrm{H}_{2} \mathrm{O} / \mathrm{MeOH}, 85$ / $15)$ to give after lyophilisation $65 \mathrm{mg}(0.09 \mathrm{mmol}, 58 \%$ yield $)$ of white solid. M. p. $211-215^{\circ} \mathrm{C}$. IR (KBr) v $\left(\mathrm{cm}^{-1}\right): 3435,2958,2928,1560$, $1508,1226 .{ }^{1} \mathrm{H}$ NMR $\left(250 \mathrm{MHz}, \mathrm{D}_{2} \mathrm{O}\right): \delta 0.81\left(\mathrm{t}, J=7.3 \mathrm{~Hz}, 3 \mathrm{H}, \mathrm{CH}_{3}\right)$, $1.20-1.29\left(\mathrm{~m}, 2 \mathrm{H}, \mathrm{CH}_{2}\right), 1.50-1.59\left(\mathrm{~m}, 2 \mathrm{H}, \mathrm{CH}_{2}\right), 2.58-2.64(\mathrm{~m}$, $\left.2 \mathrm{H}, \mathrm{CH}_{2}\right), 2.97$ (dd, A part of an ABX system, $J=8.5,14.1 \mathrm{~Hz}, 1 \mathrm{H}$, $\mathrm{PhCH}_{2}$ ), 3.23 (dd, B part of an ABX system, $J=3.3,14.1 \mathrm{~Hz}, 1 \mathrm{H}$, $\mathrm{PhCH}_{2}$ ), 4.51 (dd, $\mathrm{X}$ part of an ABX system, $J=3.3,8.5 \mathrm{~Hz}, 1 \mathrm{H}$, $\mathrm{CH}), 4.85\left(\mathrm{~s}, 2 \mathrm{H}, \mathrm{CH}_{2} \mathrm{O}\right), 5.10\left(\mathrm{~s}, 2 \mathrm{H}, \mathrm{CH}_{2} \mathrm{~N}\right), 6.59(\mathrm{~d}, J=8.1 \mathrm{~Hz}, 2 \mathrm{H}$, $\left.\mathrm{H}_{\text {arom }}\right), 6.73\left(\mathrm{~d}, J=7.8 \mathrm{~Hz}, 2 \mathrm{H}, \mathrm{H}_{\text {arom }}\right), 6.94\left(\mathrm{~d}, J=7.8 \mathrm{~Hz}, 2 \mathrm{H}, \mathrm{H}_{\text {arom }}\right)$, $7.07\left(\mathrm{~d}, J=8.1 \mathrm{~Hz}, 2 \mathrm{H}, \mathrm{H}_{\text {arom }}\right), 7.39-7.42\left(\mathrm{~m}, 1 \mathrm{H}, \mathrm{H}_{\text {arom }}\right), 7.51-7.64$ $\left(\mathrm{m}, 3 \mathrm{H}, \mathrm{H}_{\text {arom }}\right) .{ }^{13} \mathrm{C} \mathrm{NMR}\left(62.9 \mathrm{MHz}, \mathrm{D}_{2} \mathrm{O}\right): \delta 13.0\left(\mathrm{CH}_{3}\right), 21.5\left(\mathrm{CH}_{2}\right)$, $25.8\left(\mathrm{CH}_{2}\right), 29.0\left(\mathrm{CH}_{2}\right), 37.2\left(\mathrm{CH}_{2}\right), 47.3\left(\mathrm{CH}_{2} \mathrm{~N}\right), 58.5\left(\mathrm{CH}_{2} \mathrm{O}\right), 115.0$ $\left(2 \times \mathrm{CH}_{\text {arom }}\right), 121.5,125.8\left(2 \times \mathrm{CH}_{\text {arom }}\right), 127.7,127.9,128.3,129.3$ $\left(2 \times \mathrm{CH}_{\text {arom }}\right), 129.5,130.3,130.4\left(2 \times \mathrm{CH}_{\text {arom }}\right.$ and $\left.1 \times \mathrm{C}\right), 130.9,134.4$, 140.2, 140.8, 150.5, 155.8, 162.1. ESI-MS (neg. mode): $\mathrm{m} / z=626.17$ $\left([\mathrm{M}-2 \mathrm{~K}+\mathrm{H}]^{-},{ }^{35} \mathrm{Cl}\right)$. Anal. Calcd for $\mathrm{C}_{32} \mathrm{H}_{28} \mathrm{Cl} \mathrm{K}_{2} \mathrm{~N}_{7} \mathrm{O}_{3} \mathrm{~S}, \mathrm{H}_{2} \mathrm{O}$ (722.34): C, 53.21; H, 3.91; N, 13.58. Found: C, 52.93; H, 3.86; N, 13.77 .

6.1.3.6. 5-(4-\{2-Butyl-5-chloro-3-[2'-(2H-tetrazol-5-yl)biphenyl-4ylmethyl]-3H-imidazol-4-ylmethoxy\} benzylidene) thiazolidine-2,4dione (6)

To a solution of compound 3 (206 mg, $0.24 \mathrm{mmol})$ in THF $(12 \mathrm{~mL})$ was added a $2 \mathrm{~N}$ aqueous $\mathrm{HCl}$ solution $(6 \mathrm{~mL})$. The mixture was stirred at room temperature for $4 \mathrm{~h}$. The solvent was removed and the residue was dissolved in EtOAc $(30 \mathrm{~mL})$. The solution was 
washed with water $(3 \times 15 \mathrm{~mL})$, dried $\left(\mathrm{MgSO}_{4}\right)$ and the solvent was removed under vacuum to give a residue which was purified by column chromatography (eluent: $\mathrm{CH}_{2} \mathrm{Cl}_{2} / \mathrm{MeOH}, 98: 2$ ) to give $116 \mathrm{mg}$ ( $0.65 \mathrm{mmol}, 78 \%$ yield) of yellow solid. M. p. $178-180^{\circ} \mathrm{C}$. IR $(\mathrm{KBr})$ v $\left(\mathrm{cm}^{-1}\right): 3467,2952,2929,1735,1701,1595,1508,1251,1177 .{ }^{1} \mathrm{H}$ NMR $\left(250 \mathrm{MHz}\right.$, DMSO- $\left.d_{6}\right): \delta 0.81\left(\mathrm{t}, J=7.3 \mathrm{~Hz}, 3 \mathrm{H}, \mathrm{CH}_{3}\right)$, $1.21-1.30\left(\mathrm{~m}, 2 \mathrm{H}, \mathrm{CH}_{2}\right), 1.44-1.56\left(\mathrm{~m}, 2 \mathrm{H}, \mathrm{CH}_{2}\right), 5.06\left(\mathrm{~s}, 2 \mathrm{H}, \mathrm{CH}_{2} \mathrm{O}\right)$, $5.24\left(\mathrm{~s}, 2 \mathrm{H}, \mathrm{CH}_{2} \mathrm{~N}\right), 6.96-7.07\left(\mathrm{~m}, 6 \mathrm{H}, \mathrm{H}_{\text {arom }}\right), 7.48-7.73(\mathrm{~m}, 7 \mathrm{H}$, $6 \times \mathrm{H}_{\text {arom }}$ and $\left.\mathrm{CH}=\right) .{ }^{13} \mathrm{C}$ NMR $\left(62.9 \mathrm{MHz}, \mathrm{DMSO}-d_{6}\right): \delta 13.6\left(\mathrm{CH}_{3}\right)$, 21.6 $\left(\mathrm{CH}_{2}\right), 25.8\left(\mathrm{CH}_{2}\right), 28.9\left(\mathrm{CH}_{2}\right), 46.8\left(\mathrm{CH}_{2} \mathrm{~N}\right), 58.2\left(\mathrm{CH}_{2} \mathrm{O}\right), 115.5$ $\left(2 \times \mathrm{CH}_{\text {arom }}\right), 120.7,120.9,123.5,125.9,126.2\left(2 \times \mathrm{CH}_{\text {arom }}\right), 127.8$, $127.9,129.0\left(2 \times \mathrm{CH}_{\text {arom }}\right), 130.5\left(2 \times \mathrm{CH}_{\text {arom }}\right), 131.0,131.6,131.9$ $\left(2 \times \mathrm{CH}_{\text {arom }}\right), 135.8,138.5,141.0,148.9,155.0,159.2,167.5(\mathrm{C}=\mathrm{O})$, $168.0(\mathrm{C}=\mathrm{O})$. ESI-MS (neg. mode): $m / z=624.16\left([\mathrm{M}-\mathrm{H}]-{ }^{35} \mathrm{Cl}\right)$. Anal. Calcd for $\mathrm{C}_{32} \mathrm{H}_{28} \mathrm{ClN}_{7} \mathrm{O}_{3} \mathrm{~S}$ (626.13): C, 61.38; H, 4.51; N, 15.66. Found: C, 61.23; H, 4.51; N, 15.40.

\subsubsection{5-(4-\{2-Butyl-5-chloro-3-[2'-(2H-tetrazol-5-yl)biphenyl-4- ylmethyl]-3H-imidazol-4-ylmethoxy\}benzylidene)thiazolidine-2,4- dione potassium salt (7)}

A solution of $6(86 \mathrm{mg}, 0.14 \mathrm{mmol})$ in EtOAc $(30 \mathrm{~mL})$ was extracted with a $34 \mathrm{mM}$ aqueous $\mathrm{KOH}$ solution $(4 \times 5 \mathrm{~mL})$. The aqueous phases were gathered and evaporated. The residue was purified by reversed-phase column chromatography (eluent: $\mathrm{H}_{2} \mathrm{O} / \mathrm{MeOH}, 90 / 10$ ) to give after lyophilisation $71 \mathrm{mg}(0.10 \mathrm{mmol}, 73 \%$ yield $)$ of white solid. M. p. $241-243{ }^{\circ} \mathrm{C}$. IR (KBr) v $\left(\mathrm{cm}^{-1}\right): 3448,2920,1648,1560 .{ }^{1} \mathrm{H}$ NMR $\left(250 \mathrm{MHz}, \mathrm{D}_{2} \mathrm{O}\right): \delta 0.77\left(\mathrm{t}, J=7.3 \mathrm{~Hz}, 3 \mathrm{H}, \mathrm{CH}_{3}\right), 1.11-1.25(\mathrm{~m}$, $\left.2 \mathrm{H}, \mathrm{CH}_{2}\right), 1.38-1.50\left(\mathrm{~m}, 2 \mathrm{H}, \mathrm{CH}_{2}\right), 2.46-2.51\left(\mathrm{~m}, 2 \mathrm{H}, \mathrm{CH}_{2}\right), 4.64(\mathrm{~s}$, $\left.2 \mathrm{H}, \mathrm{CH}_{2} \mathrm{O}\right), 4.87\left(\mathrm{~s}, 2 \mathrm{H}, \mathrm{CH}_{2} \mathrm{~N}\right), 6.47\left(\mathrm{~d}, J=8.5 \mathrm{~Hz}, 2 \mathrm{H}, \mathrm{H}_{\text {arom }}\right), 6.56$ $\left(\mathrm{d}, J=8.0 \mathrm{~Hz}, 2 \mathrm{H}, \mathrm{H}_{\text {arom }}\right), 6.78\left(\mathrm{~d}, J=8.0 \mathrm{~Hz}, 2 \mathrm{H}, \mathrm{H}_{\text {arom }}\right), 7.12-7.18$ $\left(\mathrm{m}, 3 \mathrm{H}, \mathrm{H}_{\text {arom }}\right), 7.33(\mathrm{~s}, 1 \mathrm{H}, \mathrm{CH}=), 7.39-7.51\left(\mathrm{~m}, 2 \mathrm{H}, \mathrm{H}_{\text {arom }}\right), 7.60$ (d, $\left.J=7.1 \mathrm{~Hz}, 1 \mathrm{H}, \mathrm{H}_{\text {arom }}\right) .{ }^{13} \mathrm{C}$ NMR $\left(62.9 \mathrm{MHz}, \mathrm{D}_{2} \mathrm{O}\right): \delta 13.0\left(\mathrm{CH}_{3}\right)$, $21.5\left(\mathrm{CH}_{2}\right), 25.8\left(\mathrm{CH}_{2}\right), 28.9\left(\mathrm{CH}_{2}\right), 47.4\left(\mathrm{CH}_{2} \mathrm{~N}\right), 58.2\left(\mathrm{CH}_{2} \mathrm{O}\right), 115.0$ $\left(2 \times \mathrm{CH}_{\text {arom }}\right), 121.1,125.7\left(2 \times \mathrm{CH}_{\text {arom }}\right), 127.4,127.7,127.9,128.2$, $128.9,129.2\left(2 \times \mathrm{CH}_{\text {arom }}\right), 129.5,130.3,130.4,131.5\left(2 \times \mathrm{CH}_{\text {arom }}\right)$, 134.2, 140.2, 140.6, 150.5, 157.9, 162.0. ESI-MS (neg. mode): $m /$ $z=624.16\left([\mathrm{M}-2 \mathrm{~K}+\mathrm{H}]-{ }^{35} \mathrm{Cl}\right)$. Anal. Calcd for $\mathrm{C}_{32} \mathrm{H}_{26} \mathrm{ClK}_{2} \mathrm{~N}_{7} \mathrm{O}_{3} \mathrm{~S}$, $3 \mathrm{H}_{2} \mathrm{O}$ (756.36): C, 50.82; H, 4.26; N, 12.96. Found: C, 51.12; H, 3.93; N, 12.92 .

\subsubsection{2-Butyl-5-chloro-3-[2'-(2H-tetrazol-5-yl)biphenyl-4- ylmethyl]-3H-imidazole-4-carbaldehyde (8)}

Following a slight modification of a procedure reported by Santagada [30], to a solution of losartan potassium salt $(1.00 \mathrm{~g}, 2.17 \mathrm{mmol})$ in water $(5 \mathrm{~mL})$ was added activated $\mathrm{MnO}_{2}(1.78 \mathrm{~g}, 20.43 \mathrm{mmol})$. The suspension was irradiated in a micro-wave oven for $35 \mathrm{~min}$ at $300 \mathrm{~W}$. The solvent was removed under vacuum to give a residue which was purified by column chromatography (eluent: $\mathrm{CH}_{2} \mathrm{Cl}_{2} / \mathrm{MeOH} / \mathrm{AcOH}$, 98:2:0.1) to give $603 \mathrm{mg}$ (1.43 mmol, $66 \%$ yield) of white solid. M. p. $107^{\circ} \mathrm{C} .{ }^{1} \mathrm{H}$ NMR $\left(250 \mathrm{MHz}, \mathrm{DMSO}-d_{6}\right): \delta 0.81(\mathrm{t}, J=7.3 \mathrm{~Hz}, 3 \mathrm{H}$, $\left.\mathrm{CH}_{3}\right), 1.18-1.33\left(\mathrm{~m}, 2 \mathrm{H}, \mathrm{CH}_{2}\right), 1.43-1.57\left(\mathrm{~m}, 2 \mathrm{H}, \mathrm{CH}_{2}\right), 2.60-2.66$ $\left(\mathrm{m}, 2 \mathrm{H}, \mathrm{CH}_{2}\right), 5.58\left(\mathrm{~s}, 2 \mathrm{H}, \mathrm{CH}_{2} \mathrm{~N}\right), 7.01-7.09\left(\mathrm{~m}, 4 \mathrm{H}, \mathrm{H}_{\text {arom }}\right)$, 7.50-7.70 (m, 4H, $\left.\mathrm{H}_{\text {arom }}\right), 9.68$ (s, $\left.1 \mathrm{H}, \mathrm{CHO}\right)$.

6.1.3.9. 2-Butyl-5-chloro-3-[2'-(2-trityl-2H-tetrazol-5-yl)biphenyl-4ylmethyl]-3H-imidazole-4-carbaldehyde (9) [42]

To a solution of $8(1.02 \mathrm{~g}, 2.43 \mathrm{mmol})$ in anhydrous $\mathrm{CH}_{2} \mathrm{Cl}_{2}$ $(10 \mathrm{~mL})$ were added trimethylamine $(373 \mu \mathrm{L}, 2.68 \mathrm{mmol})$ and trityle chloride $(747 \mathrm{mg}, 2.68 \mathrm{mmol})$. The mixture was stirred at room temperature for $5 \mathrm{~h}$. EtOAc $(60 \mathrm{~mL})$ was added and the resulting solution was washed with water $(4 \times 30 \mathrm{~mL})$, dried $\left(\mathrm{MgSO}_{4}\right)$ and the solvent was removed under vacuum to give a residue which was purified by column chromatography (eluent: cyclohexane/EtOAc, $85: 15$ ) to give $1.41 \mathrm{~g}(2.13 \mathrm{mmol}, 88 \%$ yield $)$ of white solid. M. p. $86-89^{\circ} \mathrm{C} .{ }^{1} \mathrm{H}$ NMR $\left(250 \mathrm{MHz}\right.$, DMSO- $\left.d_{6}\right): \delta 0.81\left(\mathrm{t}, J=7.3 \mathrm{~Hz}, 3 \mathrm{H}, \mathrm{CH}_{3}\right)$, 1.18-1.33 (m, 2H, $\left.\mathrm{CH}_{2}\right), 1.43-1.57\left(\mathrm{~m}, 2 \mathrm{H}, \mathrm{CH}_{2}\right), 2.60-2.66(\mathrm{~m}, 2 \mathrm{H}$, $\left.\mathrm{CH}_{2}\right), 5.58\left(\mathrm{~s}, 2 \mathrm{H}, \mathrm{CH}_{2} \mathrm{~N}\right), 7.01-7.09\left(\mathrm{~m}, 4 \mathrm{H}, \mathrm{H}_{\text {arom }}\right), 7.50-7.70(\mathrm{~m}$, $\left.4 \mathrm{H}, \mathrm{H}_{\text {arom }}\right), 9.68$ (s, $\left.1 \mathrm{H}, \mathrm{CHO}\right)$.

6.1.3.10. (E)-3-\{2-Butyl-5-chloro-3-[2'-(2-trityl-2H-tetrazol-5yl)biphenyl-4-ylmethyl]-3H-imidazol-4-yl\}acrylic acid ethyl ester (10)

To a solution of $(\mathrm{EtO}){ }_{2} \mathrm{POCH}_{2} \mathrm{CO}_{2} \mathrm{Et}(620 \mu \mathrm{L}, 3.10 \mathrm{mmol})$ in anhydrous THF under argon cooled in an ice bath was added $60 \% \mathrm{NaH}$ $(116 \mathrm{mg}, 2.90 \mathrm{mmol})$ and the mixture was stirred at room temperature for $30 \mathrm{~min}$. It was then cooled in an ice bath and a solution of compound $9(1.37 \mathrm{~g}, 2.07 \mathrm{mmol})$ in anhydrous DMF $(6 \mathrm{~mL})$ was added and the resulting mixture was stirred at $0^{\circ} \mathrm{C}$ for $1 \mathrm{~h}$, then at room temperature for $1 \mathrm{~h}$. The $\mathrm{pH}$ was acidified with a $5 \%$ citric acid aqueous solution and EtOAc $(60 \mathrm{~mL})$ was added. The solution was washed with water $(4 \times 30 \mathrm{~mL})$, dried $\left(\mathrm{MgSO}_{4}\right)$ and the solvent was removed under vacuum to give a residue which was purified by column chromatography (eluent: cyclohexane/EtOAc, $85: 15$ ) to give $1.42 \mathrm{~g}$ (1.94 mmol, 94\% yield) of white solid. M. p. $85-87^{\circ} \mathrm{C}$. IR (film) v $\left(\mathrm{cm}^{-1}\right): 3447,2958,2928,1706,1628,1492,1446,1264,1171$, 1032, 747, 698. ${ }^{1} \mathrm{H}$ NMR $\left(400 \mathrm{MHz}, \mathrm{DMSO}-d_{6}\right): \delta 0.76(\mathrm{t}, J=7.3 \mathrm{~Hz}$, $\left.3 \mathrm{H}, \mathrm{CH}_{3}\right), 1.12-1.22\left(\mathrm{~m}, 5 \mathrm{H}, \mathrm{CH}_{2}\right.$ et $\left.\mathrm{CH}_{3}\right), 1.46-1.54\left(\mathrm{~m}, 2 \mathrm{H}, \mathrm{CH}_{2}\right)$, 2.42-2.58 (m, 2H, $\left.\mathrm{CH}_{2}\right), 4.07$ (q, $\left.J=7.1 \mathrm{~Hz}, 2 \mathrm{H}, \mathrm{CO}_{2} \mathrm{CH}_{2}\right), 5.32$ (s, $\left.2 \mathrm{H}, \mathrm{CH}_{2} \mathrm{~N}\right), 6.42(\mathrm{~d}, J=16.1 \mathrm{~Hz}, 1 \mathrm{H}, \mathrm{CH}=), 6.84-6.88\left(\mathrm{~m}, 8 \mathrm{H}, \mathrm{H}_{\text {arom }}\right)$, $7.08\left(\mathrm{~d}, J=8.3 \mathrm{~Hz}, 2 \mathrm{H}, \mathrm{H}_{\text {arom }}\right), 7.30-7.44\left(\mathrm{~m}, 11 \mathrm{H}, \mathrm{H}_{\text {arom }}\right.$ and $\left.\mathrm{CH}=\right)$, $7.54\left(\mathrm{td}, J=1.5,7.6 \mathrm{~Hz}, 1 \mathrm{H}, \mathrm{H}_{\text {arom }}\right), 7.60(\mathrm{td}, J=1.6,7.6 \mathrm{~Hz}, 1 \mathrm{H}$, $\left.\mathrm{H}_{\text {arom }}\right), 7.79$ (dd, $\left.J=1.5,7.6 \mathrm{~Hz}, 1 \mathrm{H}, \mathrm{H}_{\text {arom }}\right) .{ }^{13} \mathrm{C} \mathrm{NMR}(100.6 \mathrm{MHz}$, DMSO- $\left.d_{6}\right): \delta 13.5\left(\mathrm{CH}_{3}\right), 14.1\left(\mathrm{CH}_{3}\right), 21.5\left(\mathrm{CH}_{2}\right), 25.9\left(\mathrm{CH}_{2}\right), 28.7$ $\left(\mathrm{CH}_{2}\right), 46.2\left(\mathrm{CH}_{2} \mathrm{~N}\right), 60.1\left(\mathrm{CO}_{2} \mathrm{CH}_{2}\right), 82.3(\mathrm{C} \mathrm{Tr}), 115.8,121.5,125.5$ $\left(2 \times \mathrm{CH}_{\text {arom }}\right), 125.6,127.8\left(6 \times \mathrm{CH}_{\text {arom }} \mathrm{Tr}\right), 127.9,128.3\left(3 \times \mathrm{C}_{\text {arom }} \mathrm{Tr}\right.$ and $\left.1 \times \mathrm{C}_{\text {arom }}\right), 129.5\left(2 \times \mathrm{CH}_{\text {arom }}\right), 129.6\left(6 \times \mathrm{CH}_{\text {arom }} \mathrm{Tr}\right), 130.3,130.5$, $130.7,131.0,134.8,139.6,140.8\left(3 \times \mathrm{C}_{\text {arom }} \mathrm{Tr}\right), 140.9,150.5,163.3$, $166.1(\mathrm{C}=\mathrm{O})$. ESI-MS (pos. mode): $m / z=733.31\left([\mathrm{M}+\mathrm{H}]+{ }^{+},{ }^{35} \mathrm{Cl}\right)$. Anal. Calcd for $\mathrm{C}_{45} \mathrm{H}_{41} \mathrm{ClN}_{6} \mathrm{O}_{2}$ (733.30): $\mathrm{C}, 73.71 ; \mathrm{H}, 5.64 ; \mathrm{N}, 11.46$. Found: C, 74.05; H, 5.63; N, 11.55.

\subsubsection{3-\{2-Butyl-3-[2'-(2-trityl-2H-tetrazol-5-yl)biphenyl-4-} ylmethyl]-3H-imidazol-4-yl\}propionic acid ethyl ester (11) and 3-\{2butyl-5-chloro-3-[2'-(2-trityl-2H-tetrazol-5-yl)biphenyl-4-ylmethyl]3H-imidazol-4-yls propionic acid ethyl ester (12)

In a Parr flask was introduced $\mathrm{Pd} / \mathrm{C}(200 \mathrm{mg}, 10 \% \mathrm{Pd})$, then a solution of 10 ( $400 \mathrm{mg}, 0.54 \mathrm{mmol})$ in $\mathrm{MeOH}(20 \mathrm{~mL})$ was added. The suspension was shaken in the presence of $\mathrm{H}_{2}(70 \mathrm{psi})$ for $24 \mathrm{~h}$ at room temperature, filtered on celite ${ }^{\circledR}$, and the solvent was removed under vacuum. The residue was dissolved in anhydrous $\mathrm{CH}_{2} \mathrm{Cl}_{2}(4 \mathrm{~mL})$, then triethylamine $(84 \mu \mathrm{L}, 0.60 \mathrm{mmol})$ and trityl chloride $(170 \mathrm{mg}$, $0.60 \mathrm{mmol}$ ) were added. The mixture was stirred $2 \mathrm{~h}$ at room temperature and EtOAc $(30 \mathrm{~mL})$ was added. The solution was washed with water $(4 \times 10 \mathrm{~mL})$, dried $\left(\mathrm{MgSO}_{4}\right)$ and the solvent was removed under vacuum to give a residue which was purified by column chromatography (eluent: $\left.\mathrm{CH}_{2} \mathrm{Cl}_{2} / \mathrm{MeOH}, 97 / 3\right)$ to give $182 \mathrm{mg}(0.26 \mathrm{mmol}, 48 \%$ yield) of compound $\mathbf{1 1}$ (white powder, more polar compound) and $55 \mathrm{mg}(0.07 \mathrm{mmol}, 14 \%$ yield) of compound 12 (colorless liquid, less polar compound).

Compound 11. M. p. $73-75^{\circ} \mathrm{C}$. IR (film) v $\left(\mathrm{cm}^{-1}\right): 3407,2957$, 2928, 1733, 1446, 1187, 1156, 749, 698. $\left.{ }^{1} \mathrm{H} \mathrm{NMR} \mathrm{(400} \mathrm{MHz,} \mathrm{CDCl}_{3}\right)$ : $\delta 0.86\left(\mathrm{t}, J=7.3 \mathrm{~Hz}, 3 \mathrm{H}, \mathrm{CH}_{3}\right), 1.20-1.35\left(\mathrm{~m}, 5 \mathrm{H}, \mathrm{CH}_{2}\right.$ et $\left.\mathrm{CH}_{3}\right)$, 1.64-1.72 (m, 2H, $\left.\mathrm{CH}_{2}\right), 2.49-2.53\left(\mathrm{~m}, 2 \mathrm{H}, \mathrm{CH}_{2}\right), 2.60-2.68(\mathrm{~m}, 4 \mathrm{H}$, 
$\left.2 \times \mathrm{CH}_{2}\right), 4.09\left(\mathrm{q}, J=7.1 \mathrm{~Hz}, 2 \mathrm{H}, \mathrm{CO}_{2} \mathrm{CH}_{2}\right), 5.01\left(\mathrm{~s}, 2 \mathrm{H}, \mathrm{CH}_{2} \mathrm{~N}\right)$, $6.69\left(\mathrm{~d}, J=8.2 \mathrm{~Hz}, 2 \mathrm{H}, \mathrm{H}_{\text {arom }}\right), 6.88\left(\mathrm{~s}, 1 \mathrm{H}, \mathrm{H}_{\text {imidazole }}\right), 6.91-6.95(\mathrm{~m}$, $\left.6 \mathrm{H}, \mathrm{H}_{\text {arom }}\right), 7.13$ (d, J=8.2 Hz, 2H, $\left.\mathrm{H}_{\text {arom }}\right), 7.23-7.29\left(\mathrm{~m}, 6 \mathrm{H}, \mathrm{H}_{\text {arom }}\right)$, 7.32-7.37 (m, 4H, $\left.\mathrm{H}_{\text {arom }}\right), 7.42-7.52\left(\mathrm{~m}, 2 \mathrm{H}, \mathrm{H}_{\text {arom }}\right), 7.94$ (dd, $J=1.8$, $\left.7.3 \mathrm{~Hz}, 1 \mathrm{H}, \mathrm{H}_{\text {arom }}\right) .{ }^{13} \mathrm{C}$ NMR $\left(100.6 \mathrm{MHz}, \mathrm{CDCl}_{3}\right): \delta 13.8\left(\mathrm{CH}_{3}\right)$, $14.3\left(\mathrm{CH}_{3}\right), 19.7\left(\mathrm{CH}_{2}\right), 22.5\left(\mathrm{CH}_{2}\right), 26.2\left(\mathrm{CH}_{2}\right), 29.9\left(\mathrm{CH}_{2}\right), 32.3$ $\left(\mathrm{CH}_{2}\right), 46.8\left(\mathrm{CH}_{2} \mathrm{~N}\right), 61.0\left(\mathrm{CO}_{2} \mathrm{CH}_{2}\right), 83.0,121.0,125.2\left(2 \times \mathrm{CH}_{\text {arom }}\right)$, $126.4,127.8\left(6 \times \mathrm{CH}_{\text {arom }}\right), 128.0,128.5\left(3 \times \mathrm{CH}_{\text {arom }}\right), 130.1,130.2$ $\left(2 \times \mathrm{CH}_{\text {arom }}\right), 130.4\left(6 \times \mathrm{CH}_{\text {arom }}\right.$ and $\left.\mathrm{C}_{\text {arom }}\right), 130.8,131.3,133.7,141.3$, $141.4\left(3 \times \mathrm{C}_{\text {arom }}\right), 141.5,148.5,164.1,172.1(\mathrm{C}=\mathrm{O})$. ESI-MS (pos. mode): $m / z=701.36[\mathrm{M}+\mathrm{H}]^{+}$. Anal. Calcd for $\mathrm{C}_{45} \mathrm{H}_{44} \mathrm{~N}_{6} \mathrm{O}_{2}, \mathrm{H}_{2} \mathrm{O}$ (718.89): C, 75.18; H, 6.45; N, 11.69. Found: C, 74.85; H, 6.30; N, 11.43 .

Compound 12. IR (film) $v\left(\mathrm{~cm}^{-1}\right): 3445,2929,1731,1446,1251$, $1187,748,698 .{ }^{1} \mathrm{H}$ NMR $\left(250 \mathrm{MHz}, \mathrm{CDCl}_{3}\right): \delta 0.85(\mathrm{t}, J=7.3 \mathrm{~Hz}, 3 \mathrm{H}$, $\left.\mathrm{CH}_{3}\right), 1.16-1.35\left(\mathrm{~m}, 5 \mathrm{H}, \mathrm{CH}_{2}\right.$ and $\left.\mathrm{CH}_{3}\right), 1.57-1.72\left(\mathrm{~m}, 2 \mathrm{H}, \mathrm{CH}_{2}\right)$, 2.36-2.53 (m, 4H, $\left.2 \times \mathrm{CH}_{2}\right), 2.58-2.67\left(\mathrm{~m}, 2 \mathrm{H}, \mathrm{CH}_{2}\right), 4.07(\mathrm{q}, J=$ $\left.7.1 \mathrm{~Hz}, 2 \mathrm{H}, \mathrm{CO}_{2} \mathrm{CH}_{2}\right), 5.04\left(\mathrm{~s}, 2 \mathrm{H}, \mathrm{CH}_{2} \mathrm{~N}\right), 6.71(\mathrm{~d}, J=8.2 \mathrm{~Hz}, 2 \mathrm{H}$, $\left.\mathrm{H}_{\text {arom }}\right), 6.89-6.97\left(\mathrm{~m}, 6 \mathrm{H}, \mathrm{H}_{\text {arom }}\right), 7.11\left(\mathrm{~d}, J=8.2 \mathrm{~Hz}, 2 \mathrm{H}, \mathrm{H}_{\text {arom }}\right)$, $7.20-7.40\left(\mathrm{~m}, 10 \mathrm{H}, \mathrm{H}_{\text {arom }}\right), 7.42-7.54\left(\mathrm{~m}, 2 \mathrm{H}, \mathrm{H}_{\text {arom }}\right), 7.94$ (dd, $J=2.2$, $\left.6.7 \mathrm{~Hz}, 1 \mathrm{H}, \mathrm{H}_{\text {arom }}\right) .{ }^{13} \mathrm{C} \mathrm{NMR}\left(62.9 \mathrm{MHz}, \mathrm{CDCl}_{3}\right): \delta 13.9\left(\mathrm{CH}_{3}\right), 14.3$ $\left(\mathrm{CH}_{3}\right), 18.6\left(\mathrm{CH}_{2}\right), 22.5\left(\mathrm{CH}_{2}\right), 27.0\left(\mathrm{CH}_{2}\right), 30.0\left(\mathrm{CH}_{2}\right), 32.8\left(\mathrm{CH}_{2}\right)$, $47.1\left(\mathrm{CH}_{2} \mathrm{~N}\right), 60.8\left(\mathrm{CO}_{2} \mathrm{CH}_{2}\right), 83.0,124.4,125.2\left(2 \times \mathrm{CH}_{\text {arom }}\right), 126.4$, $127.4,127.8\left(6 \times \mathrm{CH}_{\text {arom }}\right), 127.9,128.1,128.4\left(3 \times \mathrm{CH}_{\text {arom }}\right), 130.0$ $\left(2 \times \mathrm{CH}_{\text {arom }}\right), 130.1,130.4\left(6 \times \mathrm{CH}_{\text {arom }}\right), 130.5,130.8,134.7,141.2$, $141.4\left(3 \times \mathrm{C}_{\text {arom }}\right), 147.1,164.1,172.4(\mathrm{C}=\mathrm{O})$. ESI-MS (pos. mode): $m / z=735.32\left([\mathrm{M}+\mathrm{H}]^{+},{ }^{35} \mathrm{Cl}\right)$. Anal. Calcd for $\mathrm{C}_{45} \mathrm{H}_{43} \mathrm{ClN}_{6} \mathrm{O}_{2}(735.31)$ : C, 73.50; H, 5.89; N, 11.43. Found: C, 73.22; H, 5.95; N, 11.45 .

\subsubsection{3-\{2-Butyl-3-[2'-(2-trityl-2H-tetrazol-5-yl)biphenyl-4- ylmethyl]-3H-imidazol-4-yls propan-1-ol (13)}

To a suspension of $\mathrm{LiAlH}_{4}(55 \mathrm{mg}, 1.44 \mathrm{mmol})$ in anhydrous THF under argon at $0^{\circ} \mathrm{C}$ was added a solution of $\mathbf{1 1}(252 \mathrm{mg}, 0.36 \mathrm{mmol})$ in anhydrous THF $(3 \mathrm{~mL})$. The suspension was stirred for $40 \mathrm{~min}$ at room temperature, and then quenched with a saturated aqueous $\mathrm{K}_{2} \mathrm{CO}_{3}$ solution $(1 \mathrm{~mL})$. EtOAc $(30 \mathrm{~mL})$ was added and the organic phase was washed with water $(3 \times 15 \mathrm{~mL})$, dried $\left(\mathrm{MgSO}_{4}\right)$ and the solvent was removed under vacuum to give a residue which was purified by column chromatography (eluent: $\mathrm{CH}_{2} \mathrm{Cl}_{2} / \mathrm{MeOH}, 98 / 2$ ) to give $200 \mathrm{mg}$ ( $0.30 \mathrm{mmol}, 84 \%$ yield) of white solid. M. p. $78-80^{\circ} \mathrm{C}$. IR (film) v $\left(\mathrm{cm}^{-1}\right): 3376,3056,2955,2867,1493,1446,1029,748,698 .{ }^{1} \mathrm{H}$ NMR $\left(250 \mathrm{MHz}, \mathrm{CDCl}_{3}\right): \delta 0.87\left(\mathrm{t}, J=7.3 \mathrm{~Hz}, 3 \mathrm{H}, \mathrm{CH}_{3}\right), 1.24-1.38(\mathrm{~m}, 2 \mathrm{H}$, $\left.\mathrm{CH}_{2}\right), 1.62-1.74\left(\mathrm{~m}, 5 \mathrm{H}, 2 \times \mathrm{CH}_{2}\right.$ and $\left.\mathrm{OH}\right), 2.35-2.41\left(\mathrm{~m}, 2 \mathrm{H}, \mathrm{CH}_{2}\right)$, 2.50-2.56 (m, 2H, $\left.\mathrm{CH}_{2}\right), 3.49\left(\mathrm{t}, J=6.1 \mathrm{~Hz}, 2 \mathrm{H}, \mathrm{CH}_{2} \mathrm{OH}\right), 4.95$ (s, $\left.2 \mathrm{H}, \mathrm{CH}_{2} \mathrm{~N}\right), 6.70\left(\mathrm{~s}, 1 \mathrm{H}, \mathrm{H}_{\text {imidazole }}\right), 6.75\left(\mathrm{~d}, J=8.1 \mathrm{~Hz}, 2 \mathrm{H}, \mathrm{H}_{\text {arom }}\right)$, 6.95-6.98 (m, 6H, $\left.\mathrm{H}_{\text {arom }}\right), 7.09$ (d, J=8.1 Hz, 2H, $\left.\mathrm{H}_{\text {arom }}\right), 7.24-7.54$ $\left(\mathrm{m}, 12 \mathrm{H}, \mathrm{H}_{\text {arom }}\right), 7.87\left(\mathrm{dd}, J=1.8,7.2 \mathrm{~Hz}, 1 \mathrm{H}, \mathrm{H}_{\text {arom }}\right) .{ }^{13} \mathrm{C} \mathrm{NMR}$ (62.9 MHz, $\left.\mathrm{CDCl}_{3}\right): \delta 13.9\left(\mathrm{CH}_{3}\right), 20.8\left(\mathrm{CH}_{2}\right), 22.6\left(\mathrm{CH}_{2}\right), 26.9\left(\mathrm{CH}_{2}\right)$, $30.1\left(\mathrm{CH}_{2}\right), 31.2\left(\mathrm{CH}_{2}\right), 46.5\left(\mathrm{CH}_{2} \mathrm{~N}\right), 61.8\left(\mathrm{CH}_{2} \mathrm{OH}\right), 83.1,123.5$, $125.3\left(2 \times \mathrm{CH}_{\text {arom }}\right), 126.4 ; 127.8\left(6 \times \mathrm{CH}_{\text {arom }}\right), 128.5\left(3 \times \mathrm{CH}_{\text {arom }}\right)$, $130.0\left(2 \times \mathrm{CH}_{\text {arom }}\right), 130.2,130.4\left(6 \times \mathrm{CH}_{\text {arom }}\right), 130.5,130.8,131.7$, 135.2, 140.9, $141.4\left(3 \times \mathrm{C}_{\text {arom }}\right), 141.5,148.5,164.3$. ESI-MS (pos. mode): $m / z=659.35[\mathrm{M}+\mathrm{H}]^{+}$. Anal. Calcd for $\mathrm{C}_{43} \mathrm{H}_{42} \mathrm{~N}_{6} \mathrm{O}(658.83)$ : C, 78.39; H, 6.43; N, 12.76. Found: C, 77.98; H, 6.51; N, 12.41 .

\subsubsection{3-\{2-Butyl-5-chloro-3-[2'-(2-trityl-2H-tetrazol-5-} yl)biphenyl-4-ylmethyl]-3H-imidazol-4-yl\}propan-1-ol (14)

The previous protocol was applied to compound $10(635 \mathrm{mg}$, $0.87 \mathrm{mmol}$ ) with $\mathrm{LiAlH}_{4}(65 \mathrm{mg}, 1.74 \mathrm{mmol})$. Purification by column chromatography (eluent: $\mathrm{CH}_{2} \mathrm{Cl}_{2} / \mathrm{EtOAc}, 80 / 20$ ) afforded $150 \mathrm{mg}$
( $0.22 \mathrm{mmol}, 25 \%$ yield) of white solid. M. p. $80-82^{\circ} \mathrm{C}$. IR (film) v $\left(\mathrm{cm}^{-1}\right)$ :

3364, 3061, 2956, 2928, 2867, 1735, 1494, 1446, 1249, 747, 698. ${ }^{1} \mathrm{H}$ NMR $\left(250 \mathrm{MHz}, \mathrm{DMSO}-d_{6}\right): \delta 0.75\left(\mathrm{t}, J=7.3 \mathrm{~Hz}, 3 \mathrm{H}, \mathrm{CH}_{3}\right)$, 1.08-1.24 (m, 2H, CH$), 1.39-1.52\left(\mathrm{~m}, 4 \mathrm{H}, 2 \times \mathrm{CH}_{2}\right), 2.34-2.41(\mathrm{~m}$, $2 \mathrm{H}, \mathrm{CH}_{2}$ ), 3.26-3.37 (m, 2H, $\left.\mathrm{CH}_{2} \mathrm{OH}\right), 4.15-4.66$ (br s, $1 \mathrm{H}, \mathrm{OH}$ ), $5.10\left(\mathrm{~s}, 2 \mathrm{H}, \mathrm{CH}_{2} \mathrm{~N}\right), 6.80-6.90\left(\mathrm{~m}, 8 \mathrm{H}, \mathrm{H}_{\text {arom }}\right), 7.07(\mathrm{~d}, J=8.1 \mathrm{~Hz}, 2 \mathrm{H}$, $\left.\mathrm{H}_{\text {arom }}\right), 7.30-7.45\left(\mathrm{~m}, 10 \mathrm{H}, \mathrm{H}_{\text {arom }}\right), 7.51-7.65\left(\mathrm{~m}, 2 \mathrm{H}, \mathrm{H}_{\text {arom }}\right), 7.79$ (dd, $\left.J=1.2,7.6 \mathrm{~Hz}, 1 \mathrm{H}, \mathrm{H}_{\text {arom }}\right) .{ }^{13} \mathrm{C}$ NMR $\left(62.9 \mathrm{MHz}, \mathrm{DMSO}-d_{6}\right): \delta 13.6$ $\left(\mathrm{CH}_{3}\right), 19.2\left(\mathrm{CH}_{2}\right), 21.6\left(\mathrm{CH}_{2}\right), 25.9\left(\mathrm{CH}_{2}\right), 29.0\left(\mathrm{CH}_{2}\right), 31.8\left(\mathrm{CH}_{2}\right)$, $46.0\left(\mathrm{CH}_{2} \mathrm{~N}\right), 59.7\left(\mathrm{CH}_{2} \mathrm{OH}\right), 82.2,121.2,123.9,125.4\left(2 \times \mathrm{CH}_{\text {arom }}\right.$ and $\left.\mathrm{C}_{\text {arom }}\right), 125.6,127.8\left(6 \times \mathrm{CH}_{\text {arom }}\right), 128.2\left(3 \times \mathrm{CH}_{\text {arom }}\right), 129.3$ $\left(2 \times \mathrm{CH}_{\text {arom }}\right), 129.5\left(6 \times \mathrm{CH}_{\text {arom }}\right), 130.3,130.5,130.6,135.7,139.3$, $140.8\left(3 \times \mathrm{C}_{\mathrm{arom}}\right), 141.0,145.9,162.7$. ESI-MS (pos. mode): $\mathrm{m} /$ $z=693.31\left([\mathrm{M}+\mathrm{H}]^{+},{ }^{35} \mathrm{Cl}\right)$. Anal. Calcd for $\mathrm{C}_{43} \mathrm{H}_{41} \mathrm{ClN}_{6} \mathrm{O}$ (693.28): C, 74.50; H, 5.96; N, 12.12. Found: C, 74.33; H, 5.96; N, 12.15 .

6.1.3.14. 5-[4-(3-\{2-Butyl-3-[2'-(2-trityl-2H-tetrazol-5-yl)biphenyl-4ylmethyl]-3H-imidazol-4-ylspropoxy)benzyl]-3-tritylthiazolidine-2,4dione (15)

To a solution of $13(220 \mathrm{mg}, 0.33 \mathrm{mmol})$ in anhydrous THF $(4 \mathrm{~mL})$ under argon were added triphenylphosphine $(115 \mathrm{mg}, 0.43 \mathrm{mmol})$ and 5-(4-hydroxybenzyl)-3-tritylthiazolidine-2,4-dione (171 mg, $0.37 \mathrm{mmol})$. The solution was cooled to $15^{\circ} \mathrm{C}$ and a solution of DEAD $(70 \mu \mathrm{L}, 0.43 \mathrm{mmol})$ in anhydrous THF $(3 \mathrm{~mL})$ was added dropwise. The mixture was stirred for $2 \mathrm{~h}$ at the same temperature, and the solvent was evaporated. The residue was purified by column chromatography (eluent: $\left.\mathrm{CH}_{2} \mathrm{Cl}_{2} / \mathrm{EtOAc}, 60 / 40\right)$ to give $158 \mathrm{mg}(0.14 \mathrm{mmol}, 43 \%$ yield) of white solid. M. p. $102-104^{\circ} \mathrm{C}$. IR (film) $v\left(\mathrm{~cm}^{-1}\right): 3418$, 3061，2952, 1693, 1512, 1448, 1299, 1248, 737, 699. ${ }^{1} \mathrm{H}$ NMR $\left(250 \mathrm{MHz}, \mathrm{CDCl}_{3}\right): \delta 0.86\left(\mathrm{t}, J=7.3 \mathrm{~Hz}, 3 \mathrm{H}, \mathrm{CH}_{3}\right), 1.23-1.35(\mathrm{~m}, 2 \mathrm{H}$, $\left.\mathrm{CH}_{2}\right), 1.62-1.74\left(\mathrm{~m}, 2 \mathrm{H}, \mathrm{CH}_{2}\right), 1.94-1.99\left(\mathrm{~m}, 2 \mathrm{H}, \mathrm{CH}_{2}\right), 2.48-2.63$ $\left(\mathrm{m}, 4 \mathrm{H}, 2 \times \mathrm{CH}_{2}\right), 3.00$ (dd, A part of an ABX system, $J=9.2,14.0 \mathrm{~Hz}$, $\left.1 \mathrm{H}, \mathrm{PhCH}_{2}\right), 3.40(\mathrm{dd}, \mathrm{B}$ part of an $\mathrm{ABX}$ system, $J=4.0,14.0 \mathrm{~Hz}$, $\left.1 \mathrm{H}, \mathrm{PhCH}_{2}\right), 3.83\left(\mathrm{t}, \mathrm{J}=5.9 \mathrm{~Hz}, 2 \mathrm{H}, \mathrm{CH}_{2} \mathrm{O}\right), 4.32(\mathrm{dd}, \mathrm{X}$ part of an ABX system, $J=4.0,9.2 \mathrm{~Hz}, 1 \mathrm{H}, \mathrm{CH}), 4.95\left(\mathrm{~s}, 2 \mathrm{H}, \mathrm{CH}_{2} \mathrm{~N}\right), 6.67-6.73$ $\left(\mathrm{m}, 4 \mathrm{H}, \mathrm{H}_{\text {arom }}\right), 6.87\left(\mathrm{~s}, 1 \mathrm{H}, \mathrm{H}_{\text {imidazole }}\right), 6.92-6.94\left(\mathrm{~m}, 6 \mathrm{H}, \mathrm{H}_{\text {arom }}\right)$, 7.03-7.36 (m, 29H, $\left.\mathrm{H}_{\text {arom }}\right), 7.41-7.53\left(\mathrm{~m}, 2 \mathrm{H}, \mathrm{H}_{\text {arom }}\right), 7.91$ (dd, $J=2.2$, $\left.6.7 \mathrm{~Hz}, 1 \mathrm{H}, \mathrm{H}_{\text {arom }}\right) .{ }^{13} \mathrm{C} \mathrm{NMR}\left(62.9 \mathrm{MHz}, \mathrm{CDCl}_{3}\right): \delta 13.9\left(\mathrm{CH}_{3}\right), 21.0$ $\left(\mathrm{CH}_{2}\right), 22.6\left(\mathrm{CH}_{2}\right), 27.7\left(\mathrm{CH}_{2}\right), 30.0\left(\mathrm{CH}_{2}\right), 37.9\left(\mathrm{CH}_{2}\right), 46.6(\mathrm{CH})$, $50.8\left(\mathrm{CH}_{2} \mathrm{~N}\right), 60.8(\mathrm{CH}), 66.5\left(\mathrm{CH}_{2} \mathrm{O}\right), 83.0,114.8\left(2 \times \mathrm{CH}_{\text {arom }}\right), 125.2$ $\left(2 \times \mathrm{CH}_{\text {arom }}\right), 126.4,126.9\left(3 \times \mathrm{CH}_{\text {arom }}\right), 127.7\left(6 \times \mathrm{CH}_{\text {arom }}\right), 127.8$ $\left(6 \times \mathrm{CH}_{\text {arom }}\right), 127.9,128.2,128.5\left(3 \times \mathrm{CH}_{\text {arom }}\right), 128.7\left(6 \times \mathrm{CH}_{\text {arom }}\right)$, $130.1\left(2 \times \mathrm{CH}_{\text {arom }}\right), 130.4\left(6 \times \mathrm{CH}_{\text {arom }}\right), 130.5,130.6\left(2 \times \mathrm{CH}_{\text {arom }}\right)$, $130.8,141.4\left(3 \times \mathrm{C}_{\text {arom }}\right), 141.7\left(3 \times \mathrm{C}_{\text {arom }}\right), 148.6,158.3,164.1,168.2$, 169.6, 173.3. ESI-MS (pos. mode): $m / z=1106.48[\mathrm{M}+\mathrm{H}]^{+}$. Anal. Calcd for $\mathrm{C}_{72} \mathrm{H}_{63} \mathrm{~N}_{7} \mathrm{O}_{3} \mathrm{~S}, \mathrm{H}_{2} \mathrm{O}$ (1124.40): C, 76.91; H, 5.83; N, 8.72. Found: C, 76.96; H, 5.79; N, 8.67.

\subsubsection{5-[4-(3-\{2-Butyl-3-[2'-(2H-tetrazol-5-yl)biphenyl-4- ylmethyl]-3H-imidazol-4-yl\}-propoxy)benzyl] thiazolidine-2,4-dione potassium salt (16)}

To a solution of compound $15(124 \mathrm{mg}, 0.11 \mathrm{mmol})$ in $\mathrm{CH}_{2} \mathrm{Cl}_{2}$ $(3 \mathrm{~mL})$ was added trifluoroacetic acid $(3 \mathrm{~mL})$. The solution was stirred at room temperature for $5 \mathrm{~min}$ and the solvent was evaporated. The residue was dissolved in THF $(3 \mathrm{~mL})$ and a $2 \mathrm{~N}$ aqueous $\mathrm{HCl}$ solution $(3 \mathrm{~mL})$ was added. The solution was stirred at room temperature for $4 \mathrm{~h}$ and the solvent was evaporated. The residue was dissolved in EtOAc $(10 \mathrm{~mL})$ and the organic phase was extracted with a $0.11 \mathrm{M}$ aqueous $\mathrm{KOH}$ solution $(4 \times 2 \mathrm{~mL})$. The aqueous phases were 
gathered and concentrated under reduced pressure. The residue was purified by reversed-phase column chromatography (eluent: $\mathrm{H}_{2} \mathrm{O}$ / $\mathrm{MeOH}, 70 / 30)$ to give after lyophilisation $54 \mathrm{mg}(0.08 \mathrm{mmol}, 70 \%$ yield) of white solid. M. p. $184-185^{\circ} \mathrm{C}$. IR $(\mathrm{KBr}) \cup\left(\mathrm{cm}^{-1}\right): 3435$, 2924, 1560, 1508, 1226. ${ }^{1} \mathrm{H}$ NMR $\left(250 \mathrm{MHz}, \mathrm{D}_{2} \mathrm{O}\right): \delta 0.75$ (t, $\left.J=7.3 \mathrm{~Hz}, 3 \mathrm{H}, \mathrm{CH}_{3}\right), 1.08-1.23\left(\mathrm{~m}, 2 \mathrm{H}, \mathrm{CH}_{2}\right), 1.37-1.48(\mathrm{~m}, 2 \mathrm{H}$, $\left.\mathrm{CH}_{2}\right), 1.59-1.72\left(\mathrm{~m}, 2 \mathrm{H}, \mathrm{CH}_{2}\right), 2.20-2.25\left(\mathrm{~m}, 2 \mathrm{H}, \mathrm{CH}_{2}\right), 2.48-2.54$ $\left(\mathrm{m}, 2 \mathrm{H}, \mathrm{CH}_{2}\right), 2.71(\mathrm{dd}, \mathrm{A}$ part of an ABX system, $J=10.0,13.4 \mathrm{~Hz}$, $1 \mathrm{H}, \mathrm{PhCH}_{2}$ ), 3.23 (dd, B part of an ABX system, $J=3.3,13.4 \mathrm{~Hz}$, $\left.1 \mathrm{H}, \mathrm{PhCH}_{2}\right), 3.54-3.64\left(\mathrm{~m}, 2 \mathrm{H}, \mathrm{CH}_{2} \mathrm{O}\right), 4.32(\mathrm{dd}, \mathrm{X}$ part of an $\mathrm{ABX}$ system, $J=3.3,10.0 \mathrm{~Hz}, 1 \mathrm{H}, \mathrm{CH}), 6.48-6.56\left(\mathrm{~m}, 4 \mathrm{H}, \mathrm{H}_{\text {arom }}\right), 6.62(\mathrm{~s}$, $\left.1 \mathrm{H}, \mathrm{H}_{\text {imidazole }}\right), 6.79$ (d, $\left.J=8.0 \mathrm{~Hz}, 2 \mathrm{H}, \mathrm{H}_{\text {arom }}\right), 6.93(\mathrm{~d}, J=8.0 \mathrm{~Hz}, 2 \mathrm{H}$, $\mathrm{H}_{\text {arom }}$ ), 7.09 (br d, $\left.J=7.7 \mathrm{~Hz}, 1 \mathrm{H}, \mathrm{H}_{\text {arom }}\right), 7.32-7.47\left(\mathrm{~m}, 2 \mathrm{H}, \mathrm{H}_{\text {arom }}\right)$, 7.61 (br d, $\left.J=7.7 \mathrm{~Hz}, 1 \mathrm{H}, \mathrm{H}_{\text {arom }}\right) .{ }^{13} \mathrm{C} \mathrm{NMR}\left(62.9 \mathrm{MHz}, \mathrm{D}_{2} \mathrm{O}\right): \delta 13.0$ $\left(\mathrm{CH}_{3}\right), 20.2\left(\mathrm{CH}_{2}\right), 21.6\left(\mathrm{CH}_{2}\right), 25.7\left(\mathrm{CH}_{2}\right), 26.8\left(\mathrm{CH}_{2}\right), 29.1\left(\mathrm{CH}_{2}\right)$, $37.8\left(\mathrm{CH}_{2}\right), 45.9\left(\mathrm{CH}_{2} \mathrm{~N}\right), 58.9(\mathrm{CH}), 66.8\left(\mathrm{CH}_{2} \mathrm{O}\right), 114.4\left(2 \times \mathrm{CH}_{\text {arom }}\right)$, 121.6, $125.3\left(2 \times \mathrm{CH}_{\text {arom }}\right), 127.7,128.3,129.3\left(2 \times \mathrm{CH}_{\text {arom }}\right.$ and $\left.\mathrm{C}_{\text {arom }}\right)$, $130.2\left(2 \times \mathrm{CH}_{\text {arom }}\right), 130.3,130.4,130.9,132.0,134.8,140.1,140.5$, 149.3, 156.8, 161.9, $189.4(\mathrm{C}=\mathrm{O}), 194.2(\mathrm{C}=\mathrm{O})$. ESI-MS (neg. mode): $m / z=620.24[\mathrm{M}-2 \mathrm{~K}+\mathrm{H}]^{-}$. Anal. Calcd for $\mathrm{C}_{34} \mathrm{H}_{33} \mathrm{~K}_{2} \mathrm{~N}_{7} \mathrm{O}_{3} \mathrm{~S}$, $4 \mathrm{H}_{2} \mathrm{O}$ (769.99): C, 53.03; H, 5.37; N, 12.73. Found: C, 52.87; H, 4.83; $\mathrm{N}, 12.56$.

\subsubsection{5-[4-(3-\{2-Butyl-5-chloro-3-[2'-(2-trityl-2H-tetrazol-5- yl)biphenyl-4-ylmethyl]-3H-imidazol-4-yl\}propoxy)benzyl]-3- tritylthiazolidine-2,4-dione (17)}

To a solution of $\mathbf{1 4}(148 \mathrm{mg}, 0.21 \mathrm{mmol})$ in anhydrous THF $(2 \mathrm{~mL})$ under argon were added triphenylphosphine $(73 \mathrm{mg}, 0.28 \mathrm{mmol})$ and 5-(4-hydroxybenzyl)-3-tritylthiazolidine-2,4-dione (109 mg, $0.23 \mathrm{mmol}$ ). The solution was cooled to $15^{\circ} \mathrm{C}$, a solution of DEAD $(44 \mu \mathrm{L}, 0.28 \mathrm{mmol})$ in anhydrous THF $(2 \mathrm{~mL})$ was added dropwise and the solution was stirred at room temperature for $1 \mathrm{~h}$. The solvent was evaporated and the residue was purified by column chromatography (eluent: $\mathrm{CH}_{2} \mathrm{Cl}_{2} / \mathrm{EtOAc}, 80 / 20$ ) to give $69 \mathrm{mg}$ of crude residue which was directly used in the next step.

6.1.3.17. 5-[4-(3-\{2-Butyl-5-chloro-3-[2'-(2H-tetrazol-5-yl)biphenyl4-ylmethyl]-3H-imidazol-4-yl\}propoxy)benzyl]thiazolidine-2,4-dione potassium salt (18)

To a solution of crude compound $\mathbf{1 7}$ in $\mathrm{CH}_{2} \mathrm{Cl}_{2}(3 \mathrm{~mL})$ was added trifluoroacetic acid $(3 \mathrm{~mL})$, the solution was stirred at room temperature for $20 \mathrm{~h}$, and the solvent was evaporated. The residue was dissolved in THF $(3 \mathrm{~mL})$ and a $2 \mathrm{~N}$ aqueous $\mathrm{HCl}$ solution $(3 \mathrm{~mL})$ was added. The solution was stirred at room temperature for $4 \mathrm{~h}$ and the solvent was evaporated. The residue was dissolved in EtOAc $(10 \mathrm{~mL})$ and the organic phase was extracted with a $0.21 \mathrm{M}$ aqueous $\mathrm{KOH}$ solution $(4 \times 2 \mathrm{~mL})$. The aqueous phases were gathered and concentrated under reduced pressure. The residue was purified by reversed-phase column chromatography (eluent: $\mathrm{H}_{2} \mathrm{O} / \mathrm{MeOH}, 70 / 30$ ) to give after lyophilisation $30 \mathrm{mg}(0.04 \mathrm{mmol}, 20 \%$ global yield from 14) of white solid. M. p. $184-185^{\circ} \mathrm{C}$. IR (KBr) v $\left(\mathrm{cm}^{-1}\right): 3435,2952,2928,1560$, $1510,1246,1227 .{ }^{1} \mathrm{H}$ NMR $\left(250 \mathrm{MHz}, \mathrm{D}_{2} \mathrm{O}\right): \delta 0.76(\mathrm{t}, J=7.3 \mathrm{~Hz}, 3 \mathrm{H}$, $\left.\mathrm{CH}_{3}\right), 1.09-1.24\left(\mathrm{~m}, 2 \mathrm{H}, \mathrm{CH}_{2}\right), 1.37-1.59\left(\mathrm{~m}, 4 \mathrm{H}, 2 \times \mathrm{CH}_{2}\right), 2.31-2.48$ $\left(\mathrm{m}, 4 \mathrm{H}, 2 \times \mathrm{CH}_{2}\right), 2.78(\mathrm{dd}, \mathrm{A}$ part of an $\mathrm{ABX}$ system, $J=9.9,14.0 \mathrm{~Hz}$, $1 \mathrm{H}, \mathrm{PhCH}_{2}$ ), 3.25 (dd, B part of an $\mathrm{ABX}$ system, $J=3.1,14.0 \mathrm{~Hz}$, $\left.1 \mathrm{H}, \mathrm{PhCH}_{2}\right), 3.57-3.62\left(\mathrm{~m}, 2 \mathrm{H}, \mathrm{CH}_{2} \mathrm{O}\right), 4.39(\mathrm{dd}, \mathrm{X}$ part of an ABX system, $J=3.1,9.9 \mathrm{~Hz}, 1 \mathrm{H}, \mathrm{CH}), 4.81\left(\mathrm{~s}, 2 \mathrm{H}, \mathrm{CH}_{2} \mathrm{~N}\right), 6.52-6.59(\mathrm{~m}$, $\left.4 \mathrm{H}, \mathrm{H}_{\text {arom }}\right), 6.84$ (d, J=8.1 Hz, $\left.2 \mathrm{H}, \mathrm{H}_{\text {arom }}\right), 6.99$ (d, $J=8.1 \mathrm{~Hz}, 2 \mathrm{H}$, $\left.\mathrm{H}_{\text {arom }}\right), 7.14$ (br d, $\left.J=7.5 \mathrm{~Hz}, 1 \mathrm{H}, \mathrm{H}_{\text {arom }}\right), 7.37-7.50$ (m, $2 \mathrm{H}, \mathrm{H}_{\text {arom }}$ ), $7.62\left(\mathrm{~d}, J=7.3 \mathrm{~Hz}, 1 \mathrm{H}, \mathrm{H}_{\text {arom }}\right) \cdot{ }^{13} \mathrm{C}$ NMR $\left(62.9 \mathrm{MHz}, \mathrm{D}_{2} \mathrm{O}\right): \delta 13.1$ $\left(\mathrm{CH}_{3}\right), 19.3\left(\mathrm{CH}_{2}\right), 21.6\left(\mathrm{CH}_{2}\right), 25.9\left(\mathrm{CH}_{2}\right), 27.1\left(\mathrm{CH}_{2}\right), 29.2\left(\mathrm{CH}_{2}\right)$,

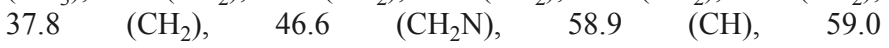

$(\mathrm{CH}), 66.7\left(\mathrm{CH}_{2} \mathrm{O}\right), 114.5\left(2 \times \mathrm{CH}_{\text {arom }}\right), 124.0,125.3\left(2 \times \mathrm{CH}_{\text {arom }}\right)$, $125.6,127.7,128.3,129.4\left(2 \times \mathrm{CH}_{\text {arom }}\right), 130.3\left(2 \times \mathrm{CH}_{\text {arom }}\right), 130.4$, $130.8,134.7,140.2,140.6,148.0,156.6,162.0,189.0(\mathrm{C}=\mathrm{O}), 194.0$ $(\mathrm{C}=\mathrm{O})$. ESI-MS (neg. mode): $m / z=654.21\left([\mathrm{M}-2 \mathrm{~K}+\mathrm{H}],{ }^{35} \mathrm{Cl}\right)$. Anal. Calcd for $\mathrm{C}_{34} \mathrm{H}_{32} \mathrm{ClK}_{2} \mathrm{~N}_{7} \mathrm{O}_{3} \mathrm{~S}, 2 \mathrm{H}_{2} \mathrm{O}$ (768.41): C, 53.14; H, 4.20; N, 12.76. Found: C, 53.01; H, 4.25; N, 12.56 .

\subsubsection{8. (E)-3-\{2-Butyl-5-chloro-3-[2'-(2-trityl-2H-tetrazol-5- \\ yl)biphenyl-4-ylmethyl]-3H-imidazol-4-yl\}acrylic acid (19)}

To a solution of compound $\mathbf{1 0}(1.20 \mathrm{~g}, 1.64 \mathrm{mmol})$ in a $1: 1 \mathrm{mix}-$ ture of THF and ethanol $(40 \mathrm{~mL})$ was added a $4.9 \mathrm{M}$ aqueous $\mathrm{NaOH}$ solution $(1 \mathrm{~mL}, 4.92 \mathrm{mmol})$. The mixture was stirred at $50{ }^{\circ} \mathrm{C}$ for $3 \mathrm{~h}$, and then the $\mathrm{pH}$ was brought acidic with a $5 \%$ aqueous citric acid. EtOAc $(150 \mathrm{~mL})$ was added and the organic phase was washed with water $(4 \times 50 \mathrm{~mL})$, dried $\left(\mathrm{MgSO}_{4}\right)$ and the solvent was removed under vacuum to give $1.15 \mathrm{~g}(1.63 \mathrm{mmol}, 100 \%$ yield $)$ of white solid. M. p. $77-79^{\circ} \mathrm{C}$. IR (film) v $\left(\mathrm{cm}^{-1}\right)$ : $3402,3061,2958,2928,2867$, $1700,1627,1446,1265,747,698 .{ }^{1} \mathrm{H}$ NMR $\left(250 \mathrm{MHz}, \mathrm{CDCl}_{3}\right): \delta$ $0.85\left(\mathrm{t}, J=7.3 \mathrm{~Hz}, 3 \mathrm{H}, \mathrm{CH}_{3}\right), 1.20-1.30\left(\mathrm{~m}, 2 \mathrm{H}, \mathrm{CH}_{2}\right), 1.58-1.72(\mathrm{~m}$, $\left.2 \mathrm{H}, \mathrm{CH}_{2}\right), 2.47-2.54\left(\mathrm{~m}, 2 \mathrm{H}, \mathrm{CH}_{2}\right), 5.03\left(\mathrm{~s}, 2 \mathrm{H}, \mathrm{CH}_{2} \mathrm{~N}\right), 6.52(\mathrm{~d}$, $J=16.0 \mathrm{~Hz}, 1 \mathrm{H}, \mathrm{CH}=), 6.73\left(\mathrm{~d}, J=8.1 \mathrm{~Hz}, 2 \mathrm{H}, \mathrm{H}_{\text {arom }}\right), 6.88-6.96(\mathrm{~m}$, $\left.6 \mathrm{H}, \mathrm{H}_{\text {arom }}\right), 7.11\left(\mathrm{~d}, J=8.1 \mathrm{~Hz}, 2 \mathrm{H}, \mathrm{H}_{\text {arom }}\right), 7.16-7.39\left(\mathrm{~m}, 12 \mathrm{H}, \mathrm{H}_{\text {arom }+}\right.$ $\mathrm{CH}=), 7.43-7.49\left(\mathrm{~m}, 1 \mathrm{H}, \mathrm{H}_{\text {arom }}\right), 7.90-7.97\left(\mathrm{~m}, 1 \mathrm{H}, \mathrm{H}_{\text {arom }}\right) .{ }^{13} \mathrm{C} \mathrm{NMR}$ $\left(62.9 \mathrm{MHz}, \mathrm{CDCl}_{3}\right): \delta 13.9\left(\mathrm{CH}_{3}\right), 22.5\left(\mathrm{CH}_{2}\right), 27.1\left(\mathrm{CH}_{2}\right), 29.6\left(\mathrm{CH}_{2}\right)$, $47.2\left(\mathrm{CH}_{2} \mathrm{~N}\right), 83.1,115.9,122.1,125.3\left(2 \times \mathrm{CH}_{\text {arom }}\right), 126.3,127.8$ $\left(6 \times \mathrm{CH}_{\text {arom }}\right), 128.0,128.1\left(2 \times \mathrm{CH}_{\text {arom }}\right), 128.4\left(3 \times \mathrm{CH}_{\text {arom }}\right), 129.9$, $130.2,130.3\left(2 \times \mathrm{CH}_{\text {arom }}\right), 130.4\left(6 \times \mathrm{CH}_{\text {arom }}\right), 130.9,133.4,141.3$, $141.4\left(3 \times \mathrm{C}_{\text {arom }}\right), 141.5,151.1,164.0,171.1$. ESI-MS (neg. mode): $m /$ $z=703.26\left([\mathrm{M}-\mathrm{H}]^{-},{ }^{35} \mathrm{Cl}\right)$. Anal. Calcd for $\mathrm{C}_{43} \mathrm{H}_{37} \mathrm{ClN}_{6} \mathrm{O}_{2}(705.25)$ : C, 73.23; H, 5.29; N, 11.92. Found: C, 73.12; H, 5.35; N, 12.88 .

6.1.3.19. (E)-3-\{2-Butyl-5-chloro-3-[2'-(2-trityl-2H-tetrazol-5-yl)biphenyl-4-ylmethyl]-3H-imidazol-4-yl\}-acrylic acid 4-(2,4-dioxo-3trityl-thiazolidin-5-ylmethyl)-phenyl ester (20)

To a solution of $19(240 \mathrm{mg}, 0.34 \mathrm{mmol})$ in $\mathrm{CH}_{2} \mathrm{Cl}_{2}(4 \mathrm{~mL})$ were added 5-(4-hydroxybenzyl)-3-tritylthiazolidine-2,4-dione (174 mg, $0.37 \mathrm{mmol})$, PyBop (177 mg, $0.34 \mathrm{mmol})$, and DIEA $(0.12 \mathrm{~mL}$, $0.68 \mathrm{mmol})$. The mixture was stirred at room temperature under argon for $24 \mathrm{~h}$, and then EtOAc $(30 \mathrm{~mL})$ was added. The organic phase was washed with a $5 \%$ aqueous $\mathrm{NaHCO}_{3}$ solution $(2 \times 15 \mathrm{~mL})$, a $5 \%$ aqueous citric acid $(2 \times 15 \mathrm{~mL})$, water $(3 \times 15 \mathrm{~mL})$, dried $\left(\mathrm{MgSO}_{4}\right)$ and the solvent was removed under vacuum. The residue was purified by column chromatography (eluent: cyclohexane $/ \mathrm{Et}_{2} \mathrm{O}, 70 / 30$ ) to give $196 \mathrm{mg}(0.17 \mathrm{mmol}, 50 \%$ yield $)$ of white solid. M. p. $122-124^{\circ} \mathrm{C}$. IR (film) $v\left(\mathrm{~cm}^{-1}\right): 3434,3061,2957,2928,1725,1689,1625,1449$, $1266,1203,1137 .{ }^{1} \mathrm{H}$ NMR $\left(250 \mathrm{MHz}, \mathrm{CDCl}_{3}\right): \delta 0.87(\mathrm{t}, J=7.3 \mathrm{~Hz}$, $\left.3 \mathrm{H}, \mathrm{CH}_{3}\right), 1.23-1.36\left(\mathrm{~m}, 2 \mathrm{H}, \mathrm{CH}_{2}\right), 1.61-1.76\left(\mathrm{~m}, 2 \mathrm{H}, \mathrm{CH}_{2}\right)$, 2.48-2.58 (m, 2H, $\left.\mathrm{CH}_{2}\right), 3.05$ (dd, A part of an ABX system, $J=9.3$, $\left.14.1 \mathrm{~Hz}, 1 \mathrm{H}, \mathrm{PhCH}_{2}\right), 3.49$ (dd, B part of an ABX system, $J=3.9$, $\left.14.1 \mathrm{~Hz}, 1 \mathrm{H}, \mathrm{PhCH}_{2}\right), 4.37(\mathrm{dd}, \mathrm{X}$ part of an ABX system, $J=3.9$, $9.3 \mathrm{~Hz}, 1 \mathrm{H}, \mathrm{CH}), \quad 5.07\left(\mathrm{~s}, 2 \mathrm{H}, \mathrm{CH}_{2} \mathrm{~N}\right), 6.69-6.81(\mathrm{~m}, 3 \mathrm{H}$, $\left.2 \times \mathrm{H}_{\text {arom }}+\mathrm{CH}=\right), 6.88-6.98\left(\mathrm{~m}, 6 \mathrm{H}, \mathrm{H}_{\text {arom }}\right), 7.01(\mathrm{~d}, J=8.3 \mathrm{~Hz}, 2 \mathrm{H}$, $\left.\mathrm{H}_{\text {arom }}\right), 7.09-7.39\left(\mathrm{~m}, 29 \mathrm{H}, \mathrm{H}_{\text {arom }}+\mathrm{CH}=\right), 7.44-7.57\left(\mathrm{~m}, 3 \mathrm{H}, \mathrm{H}_{\text {arom }}\right)$, $7.93\left(\mathrm{dd}, J=2.1,5.7 \mathrm{~Hz}, 1 \mathrm{H}, \mathrm{H}_{\text {arom }}\right) .{ }^{13} \mathrm{C} \mathrm{NMR}\left(62.9 \mathrm{MHz}, \mathrm{CDCl}_{3}\right)$ : $\delta 13.7\left(\mathrm{CH}_{3}\right), 22.3\left(\mathrm{CH}_{2}\right), 27.0\left(\mathrm{CH}_{2}\right), 29.7\left(\mathrm{CH}_{2}\right), 38.2,47.3,50.4$, 77.4, 82.9, 115.6, 121.9, $122.1\left(2 \times \mathrm{CH}_{\text {arom }}\right), 125.2,126.4,126.9$ $\left(2 \times \mathrm{CH}_{\text {arom }}\right), \quad 127.4, \quad 127.8 \quad\left(12 \times \mathrm{CH}_{\text {arom }}\right), \quad 128.0, \quad 128.1, \quad 128.4$ $\left(2 \times \mathrm{CH}_{\text {arom }}\right), \quad 128.6 \quad\left(6 \times \mathrm{CH}_{\text {arom }}\right), \quad 129.8, \quad 130.2, \quad 130.3, \quad 130.4$ $\left(12 \times \mathrm{CH}_{\text {arom }}\right), 130.9,133.4,133.5,141.3,141.4\left(3 \times \mathrm{C}_{\text {arom }}\right), 141.6$, $141.7\left(3 \times \mathrm{C}_{\text {arom }}\right), 150.4,151.1,164.1,165.6,169.5(\mathrm{C}=\mathrm{O}), 173.2$ $(\mathrm{C}=\mathrm{O})$. ESI-MS (pos. mode): $m / z=1152.40\left([\mathrm{M}+\mathrm{H}],{ }^{-}{ }^{35} \mathrm{Cl}\right)$. Anal. 
Calcd for $\mathrm{C}_{72} \mathrm{H}_{58} \mathrm{ClN}_{7} \mathrm{O}_{4} \mathrm{~S}$ (1152.79): C, 75.02; H, 5.07; N, 8.51. Found: C, 74.85; H, 5.22; N, 8.38.

\subsubsection{0. (E)-3-\{2-Butyl-5-chloro-3-[2'-(2-trityl-2H-tetrazol-5-} yl)biphenyl-4-ylmethyl]-3H-imidazol-4-yl\}acrylic acid 4-(2,4-dioxothiazolidin-5-ylmethyl)phenyl ester (21)

To a solution of compound $20(163 \mathrm{mg}, 0.14 \mathrm{mmol})$ in $\mathrm{CH}_{2} \mathrm{Cl}_{2}$ $(5 \mathrm{~mL})$ was added trifluoroacetic acid $(0.5 \mathrm{~mL})$. The mixture was stirred 1 minat room temperature. The solvent was removed under vacuum to give a residue which was purified by column chromatography (eluent: Cyclohexane/EtOAc, 80/20) to give $104 \mathrm{mg}(0.11 \mathrm{mmol}$, $81 \%$ yield) of white solid (compound 21), along with $13 \mathrm{mg}$ (0.02 mmol, $14 \%$ yield) of compound 22. M. p. $121-123^{\circ} \mathrm{C}$. IR (film) v $\left(\mathrm{cm}^{-1}\right): 3208,3061,2958,2928,1703,1626,1202,1141 .{ }^{1} \mathrm{H}$ NMR $\left(250 \mathrm{MHz}, \mathrm{DMSO}-d_{6}\right): \delta 0.77\left(\mathrm{t}, J=7.3 \mathrm{~Hz}, 3 \mathrm{H}, \mathrm{CH}_{3}\right), 1.11-1.28(\mathrm{~m}$, $\left.2 \mathrm{H}, \mathrm{CH}_{2}\right), 1.45-1.59\left(\mathrm{~m}, 2 \mathrm{H}, \mathrm{CH}_{2}\right), 3.12$ (dd, A part of an ABX system, $J=9.1,14.1 \mathrm{~Hz}, 1 \mathrm{H}, \mathrm{PhCH}_{2}$ ), 3.39 (dd, B part of an ABX system, $\left.J=4.4,14.1 \mathrm{~Hz}, 1 \mathrm{H}, \mathrm{PhCH}_{2}\right), 4.92$ (dd, X part of an ABX system, $J=4.4,9.1 \mathrm{~Hz}, 1 \mathrm{H}, \mathrm{CH}), 5.37\left(\mathrm{~s}, 2 \mathrm{H}, \mathrm{CH}_{2} \mathrm{~N}\right), 6.62(\mathrm{~d}, J=16.0 \mathrm{~Hz}, 1 \mathrm{H}$, $\mathrm{CH}=), 6.80-6.94\left(\mathrm{~m}, 8 \mathrm{H}, \mathrm{H}_{\text {arom }}\right), 7.00-7.13\left(\mathrm{~m}, 4 \mathrm{H}, \mathrm{H}_{\text {arom }}\right), 7.22-7.47$ $\left(\mathrm{m}, 12 \mathrm{H}, \mathrm{H}_{\text {arom }}\right), 7.50-7.65\left(\mathrm{~m}, 3 \mathrm{H}, \mathrm{H}_{\text {arom }}+\mathrm{CH}=\right), 7.79$ (br d, $\left.J=7.4 \mathrm{~Hz}, 1 \mathrm{H}, \mathrm{H}_{\text {arom }}\right), 12.04$ (br s, $\left.1 \mathrm{H}, \mathrm{NH}\right) .{ }^{13} \mathrm{C} \mathrm{NMR}(62.9 \mathrm{MHz}$, DMSO-d $\left.{ }_{6}\right): \delta 13.5\left(\mathrm{CH}_{3}\right), 21.6\left(\mathrm{CH}_{2}\right), 25.9\left(\mathrm{CH}_{2}\right), 28.7\left(\mathrm{CH}_{2}\right), 36.5$ $\left(\mathrm{CH}_{2}\right), \quad 46.3\left(\mathrm{CH}_{2} \mathrm{~N}\right), \quad 52.6(\mathrm{CH}), \quad 82.2, \quad 114.3, \quad 121.5, \quad 121.6$ $\left(2 \times \mathrm{CH}_{\text {arom }}\right), 125.5,125.6,127.8\left(6 \times \mathrm{CH}_{\text {arom }}\right), 128.3\left(3 \times \mathrm{CH}_{\text {arom }}\right)$, $129.5\left(6 \times \mathrm{CH}_{\text {arom }}\right), 130.1,130.2\left(2 \times \mathrm{CH}_{\text {arom }}\right), 130.3,130.5,130.6$, $131.9,134.3,134.8,139.6,140.7\left(3 \times \mathrm{C}_{\text {arom }}\right), 140.8,149.4,151.1$, 163.3, 164.8, $171.5(\mathrm{C}=\mathrm{O}), 175.6(\mathrm{C}=\mathrm{O})$. ESI-MS (neg. mode): $\mathrm{m} /$ $z=908.28\left([\mathrm{M}-\mathrm{H}]^{-},{ }^{35} \mathrm{Cl}\right)$. Anal. Calcd for $\mathrm{C}_{53} \mathrm{H}_{44} \mathrm{ClN}_{7} \mathrm{O}_{4} \mathrm{~S}(910.48)$ : C, 69.92; H, 4.87; N, 10.77. Found: C, 69.85; H, 4.92; N, 10.78 .

6.1.3.21. (E)-3-\{2-Butyl-5-chloro-3-[2'-(2H-tetrazol-5-yl)biphenyl-4ylmethyl]-3H-imidazol-4-yl\}acrylic acid 4-(2,4-dioxo-thiazolidin-5ylmethyl)phenyl ester (22)

To a solution of $21(97 \mathrm{mg}, 0.11 \mathrm{mmol})$ in THF ( $3 \mathrm{~mL})$ was added a $2 \mathrm{M}$ aqueous $\mathrm{HCl}$ solution $(3 \mathrm{~mL})$. The mixture was stirred at room temperature for $8 \mathrm{~h}$, EtOAc $(30 \mathrm{~mL})$ was added and the solution was washed with water $(3 \times 15 \mathrm{~mL})$, dried $\left(\mathrm{MgSO}_{4}\right)$, and the solvent was evaporated. The residue was purified by column chromatography (eluent: $\left.\mathrm{CH}_{2} \mathrm{Cl}_{2} / \mathrm{MeOH}, 98 / 2\right)$ to give $59 \mathrm{mg}(0.09 \mathrm{mmol}, 83 \%$ yield $)$ of white solid. M. p. $132-134^{\circ} \mathrm{C}$. IR $(\mathrm{KBr}) \cup\left(\mathrm{cm}^{-1}\right): 3437,2957,2928$, $1701,1625,1507,1268,1202,1143 .{ }^{1} \mathrm{H}$ NMR $\left(250 \mathrm{MHz}, \mathrm{DMSO}-d_{6}\right)$ : $\delta 0.84\left(\mathrm{t}, J=7.3 \mathrm{~Hz}, 3 \mathrm{H}, \mathrm{CH}_{3}\right), 1.22-1.37\left(\mathrm{~m}, 2 \mathrm{H}, \mathrm{CH}_{2}\right), 1.50-1.62$ (m, 2H, $\left.\mathrm{CH}_{2}\right), 2.64-2.70\left(\mathrm{~m}, 2 \mathrm{H}, \mathrm{CH}_{2}\right), 3.10-3.19$ (m, A part of an ABX system, $\left.1 \mathrm{H}, \mathrm{PhCH}_{2}\right), 3.36-3.43$ (m, B part of an $\mathrm{ABX}$ system, $1 \mathrm{H}, \mathrm{PhCH}_{2}$ ), 4.93 (dd, X part of an $\mathrm{ABX}$ system, $J=4.6,8.9 \mathrm{~Hz}, 1 \mathrm{H}$, $\mathrm{CH}), 5.46\left(\mathrm{~s}, 2 \mathrm{H}, \mathrm{CH}_{2} \mathrm{~N}\right), 6.62(\mathrm{~d}, J=16.0 \mathrm{~Hz}, 1 \mathrm{H}, \mathrm{CH}=), 6.98(\mathrm{~d}$, $\left.J=8.1 \mathrm{~Hz}, 2 \mathrm{H}, \mathrm{H}_{\text {arom }}\right), 7.08-7.15\left(\mathrm{~m}, 4 \mathrm{H}, \mathrm{H}_{\text {arom }}\right), 7.29$ (d, $J=8.1 \mathrm{~Hz}$, $\left.2 \mathrm{H}, \mathrm{H}_{\text {arom }}\right), 7.49-7.71\left(\mathrm{~m}, 5 \mathrm{H}, 4 \times \mathrm{H}_{\text {arom }}+\mathrm{CH}=\right) .{ }^{13} \mathrm{C} \mathrm{NMR}(62.9 \mathrm{MHz}$, DMSO-d $\left.{ }_{6}\right): \delta 13.6\left(\mathrm{CH}_{3}\right), 21.6\left(\mathrm{CH}_{2}\right), 25.9\left(\mathrm{CH}_{2}\right), 28.8\left(\mathrm{CH}_{2}\right), 36.5$ $\left(\mathrm{CH}_{2}\right), 46.3\left(\mathrm{CH}_{2} \mathrm{~N}\right), 52.5(\mathrm{CH}), 114.2,121.5,121.7\left(2 \times \mathrm{C}_{\text {arom }}\right), 123.7$, $125.8\left(2 \times \mathrm{C}_{\text {arom }}\right), 127.8,129.4\left(2 \times \mathrm{C}_{\text {arom }}\right), 130.1,130.2\left(2 \times \mathrm{C}_{\text {arom }}\right)$, $130.5\left(2 \times \mathrm{C}_{\text {arom }}\right), 130.9,131.9,134.3,135.4,138.7,140.8,149.4$, 151.2, $164.8(\mathrm{C}=\mathrm{O}), 171.5(\mathrm{C}=\mathrm{O}), 175.6(\mathrm{C}=\mathrm{O})$. ESI-MS (neg. mode): $m / z=666.17\left([\mathrm{M}-\mathrm{H}]-,{ }^{35} \mathrm{Cl}\right)$. Anal. Calcd for $\mathrm{C}_{34} \mathrm{H}_{30} \mathrm{ClN}_{7} \mathrm{O}_{4} \mathrm{~S}$, $1 / 2 \mathrm{H}_{2} \mathrm{O}$ (677.17): $\mathrm{C}, 60.30 ; \mathrm{H}, 4.61 ; \mathrm{N}, 14.48$. Found: $\mathrm{C}, 60.10 ; \mathrm{H}$, $4.65 ; \mathrm{N}, 14.12$.

6.1.3.22. (S)-2-[1-tert-Butoxycarbonyl-2-(4-

hydroxyphenyl)ethylamino]benzoic acid methyl ester (23)

To a solution of L-tyrosine $t$-butyl ester $(2.37 \mathrm{~g}, 10.00 \mathrm{mmol})$ in anhydrous methanol $(30 \mathrm{~mL})$ were added 2-oxocyclohexanecar- boxylic acid methyl ester $(1.41 \mathrm{~mL}, 10.00 \mathrm{mmol})$ and $4 \AA$ molecular sieves. The mixture was stirred at reflux for $12 \mathrm{~h}$ under argon. The suspension was filtered on Celite and washed with a 1:1 mixture of $\mathrm{CH}_{2} \mathrm{Cl}_{2}$ and methanol $(3 \times 10 \mathrm{~mL})$. The solution was concentrated under reduced pressure to give an orange residue which was dissolved in anisole $(100 \mathrm{~mL})$. To the solution was added $\mathrm{Pd} / \mathrm{C}(1.06 \mathrm{~g}, 10 \%$ $\mathrm{Pd}$ ), and the suspension was stirred at reflux under argon for $5 \mathrm{~h}$. The solvent was evaporated to give a residue which was purified by column chromatography (eluent: hexane/EtOAc, 70/30) to give $1.24 \mathrm{~g}$ (3.34 mmol, 33\% yield) of yellow liquid. IR (film) v $\left(\mathrm{cm}^{-1}\right): 3342$, 2977, 2931, 1736, 1693, 1608, 1512, 1368, 1247, 1127, 1047. ${ }^{1} \mathrm{H}$ NMR $\left(250 \mathrm{MHz}, \mathrm{CDCl}_{3}\right): \delta 1.37(\mathrm{~s}, 9 \mathrm{H}, t \mathrm{Bu}), 3.09\left(\mathrm{~m}, 2 \mathrm{H}, \mathrm{CH}_{2}\right), 3.86(\mathrm{~s}$, $\left.3 \mathrm{H}, \mathrm{OCH}_{3}\right), 4.28(\mathrm{~m}, 1 \mathrm{H}, \mathrm{CH}), 5.05($ br s, $1 \mathrm{H}, \mathrm{OH}), 6.64(\mathrm{~m}, 2 \mathrm{H}$, $\left.\mathrm{H}_{\text {arom }}\right), 6.76\left(\mathrm{~d}, J=8.5 \mathrm{~Hz}, 2 \mathrm{H}, \mathrm{H}_{\text {arom }}\right), 7.11\left(\mathrm{~d}, J=8.5 \mathrm{~Hz}, 2 \mathrm{H}, \mathrm{H}_{\text {arom }}\right)$, $7.31\left(\mathrm{dt}, J=7.8,1.8 \mathrm{~Hz}, 1 \mathrm{H}, \mathrm{H}_{\text {arom }}\right), 7.91(\mathrm{dd}, J=7.9,1.2 \mathrm{~Hz}, 1 \mathrm{H}$, $\left.\mathrm{H}_{\text {arom }}\right), 8.15(\mathrm{~d}, J=7.5 \mathrm{~Hz}, 1 \mathrm{H}, \mathrm{NH}) .{ }^{13} \mathrm{C} \mathrm{NMR}\left(62.9 \mathrm{MHz}, \mathrm{CDCl}_{3}\right): \delta$ 28.1, 38.0, 51.7, 58.4, 82.0, 111.2, 111.8, 115.4, 115.6, 128.8, 130.8, $132.0,134.6,149.8,154.8,168.9,172.0$. ESI-MS (pos. mode): $m /$ $z=394.23\left([\mathrm{M}+\mathrm{Na}]^{+}\right)$. Anal. Calcd for $\mathrm{C}_{21} \mathrm{H}_{25} \mathrm{NO}_{5}$ (371.43): C, 67.91; H, 6.78; N, 3.77. Found: C, 68.15; H, 6.94; N, 3.70 .

6.1.3.23. (S,E)-2-\{1-tert-Butoxycarbonyl-2-[4-(3-\{2-butyl-5-chloro-3[2'-(2-trityl-2H-tetrazol-5-yl)biphenyl-4-ylmethyl]-3H-imidazol-4yl; acryloyloxy)phenyl]ethylamino benzoic acid methyl ester (24)

To a solution of $19(298 \mathrm{mg}, 0.42 \mathrm{mmol})$ in $\mathrm{CH}_{2} \mathrm{Cl}_{2}(5 \mathrm{~mL})$ were added compound 23 (173 mg, $0.47 \mathrm{mmol})$, PyBOP (220 mg, $0.42 \mathrm{mmol})$, and DIEA $(0.15 \mathrm{~mL}, 0.85 \mathrm{mmol})$. The mixture was stirred at room temperature under argon for $24 \mathrm{~h}$. EtOAc $(30 \mathrm{~mL})$ was added and the solution was washed with a $5 \%$ aqueous $\mathrm{NaHCO}_{3}$ solution $(2 \times 15 \mathrm{~mL})$, a $5 \%$ aqueous citric acid solution $(2 \times 15 \mathrm{~mL})$, and water $(3 \times 15 \mathrm{~mL})$. The organic phase was dried $\left(\mathrm{MgSO}_{4}\right)$, and the solvent was evaporated. The residue was purified by column chromatography (eluent: cyclohexane/diisopropyl ether, 40/60) to give $275 \mathrm{mg}$ $\left(0.26 \mathrm{mmol}, 62 \%\right.$ yield) of white solid. M. p. $82-84^{\circ} \mathrm{C}$. IR (film) v $\left(\mathrm{cm}^{-1}\right): 3341,2957,1730,1686,1626,1507,1261,1201,1145 .{ }^{1} \mathrm{H}$ NMR $\left(250 \mathrm{MHz}\right.$, DMSO- $\left.d_{6}\right): \delta 0.77\left(\mathrm{t}, J=7.3 \mathrm{~Hz}, 3 \mathrm{H}, \mathrm{CH}_{3}\right)$, 1.13-1.29 (m, 11H, $\left.\mathrm{CH}_{2}+t \mathrm{Bu}\right), 1.44-1.59\left(\mathrm{~m}, 2 \mathrm{H}, \mathrm{CH}_{2}\right), 3.04-3.13$ $\left(\mathrm{m}, 2 \mathrm{H}, \mathrm{PhCH}_{2}\right), 3.78\left(\mathrm{~s}, 3 \mathrm{H}, \mathrm{OCH}_{3}\right), 4.40-4.51(\mathrm{~m}, 1 \mathrm{H}, \mathrm{CH}), 5.37$ (s, $\left.2 \mathrm{H}, \mathrm{CH}_{2} \mathrm{~N}\right), 6.59-6.69\left(\mathrm{~m}, 2 \mathrm{H}, \mathrm{H}_{\text {arom }}+\mathrm{CH}=\right), 6.77(\mathrm{~d}, J=8.5 \mathrm{~Hz}, 1 \mathrm{H}$, $\left.\mathrm{H}_{\text {arom }}\right), 6.81-6.92\left(\mathrm{~m}, 8 \mathrm{H}, \mathrm{H}_{\text {arom }}\right), 7.00$ (d, J=8.5 Hz, 2H, $\left.\mathrm{H}_{\text {arom }}\right), 7.08$ (d, $\left.J=8.1 \mathrm{~Hz}, 2 \mathrm{H}, \mathrm{H}_{\text {arom }}\right), 7.21-7.46\left(\mathrm{~m}, 13 \mathrm{H}, \mathrm{H}_{\text {arom }}\right), 7.50-7.65(\mathrm{~m}$, $\left.3 \mathrm{H}, 2 \times \mathrm{H}_{\text {arom }}+\mathrm{CH}=\right), 7.76-7.85\left(\mathrm{~m}, 2 \mathrm{H}, \mathrm{H}_{\text {arom }}\right), 7.99(\mathrm{~d}, J=7.9 \mathrm{~Hz}$, $\left.1 \mathrm{H}, \mathrm{H}_{\text {arom }}\right) .{ }^{13} \mathrm{C}$ NMR $\left(62.9 \mathrm{MHz}, \mathrm{DMSO}-d_{6}\right): \delta 13.5\left(\mathrm{CH}_{3}\right), 21.5$ $\left(\mathrm{CH}_{2}\right), 25.9\left(\mathrm{CH}_{2}\right), 27.4(t \mathrm{Bu}), 28.36\left(\mathrm{CH}_{2}\right), 37.0,46.2,51.6,56.6$, $81.2,82.3,110.0,112.1,112.6,114.5,115.5,121.3\left(\mathrm{CH}_{\text {arom }}\right), 121.5$, 124.8, $125.5\left(\mathrm{CH}_{\text {arom }}\right), 125.6,127.8\left(\mathrm{CH}_{\text {arom }}\right), 128.2\left(\mathrm{CH}_{\text {arom }}\right), 129.5$ $\left(\mathrm{CH}_{\text {arom }}\right), 130.0,130.2,130.3\left(\mathrm{CH}_{\text {arom }}\right), 130.5,130.6,131.2,131.8$, $133.9,134.8\left(\mathrm{C}_{\text {arom }}\right), 139.1,139.6,140.7\left(\mathrm{C}_{\text {arom }}\right), 140.8,149.1,149.2$, 151.0, 163.6, 164.8, $167.9(\mathrm{C}=\mathrm{O}), 170.9(\mathrm{C}=\mathrm{O})$. ESI-MS (pos. mode): $m / z=1058.44\left([\mathrm{M}+\mathrm{H}]^{+},{ }^{35} \mathrm{Cl}\right)$. Anal. Calcd for $\mathrm{C}_{64} \mathrm{H}_{60} \mathrm{ClN}_{7} \mathrm{O}_{6}$ (1058.66): C, 72.61; H, 5.71; N, 9.26. Found: C, 73.00; H, 6.10; N, 9.21 .

6.1.3.24. (S, E)-2-\{2-[4-(3-\{2-butyl-5-chloro-3-[2'-(2H-tetrazol-5yl)biphenyl-4-ylmethyl]-3H-imidazol-4-yl\}acryloyloxy)phenyl]-1carboxy-ethylamino benzoic acid methyl ester (25)

To a solution of compound $24(220 \mathrm{mg}, 0.21 \mathrm{mmol})$ in $\mathrm{CH}_{2} \mathrm{Cl}_{2}$ $(5 \mathrm{~mL})$ was added trifluoroacetic acid $(5 \mathrm{~mL})$. The solution was stirred at room temperature for $3.5 \mathrm{~h}$ and the solvent was evaporated. The residue was dissolved in THF $(3 \mathrm{~mL})$ and a $3 \mathrm{~N}$ aqueous $\mathrm{HCl}$ solution $(3 \mathrm{~mL})$ was added. The mixture was stirred at room tempera- 
ture for $5 \mathrm{~h}$. EtOAc $(30 \mathrm{~mL})$ was added and the solution was washed with water $(3 \times 15 \mathrm{~mL})$. The organic phase was dried $\left(\mathrm{MgSO}_{4}\right)$, and the solvent was evaporated. The residue was purified by column chromatography (eluent: $\mathrm{CH}_{2} \mathrm{Cl}_{2} / \mathrm{MeOH}, 90 / 10$ ) to give $105 \mathrm{mg}$ $(0.14 \mathrm{mmol}, 66 \%$ yield $)$ of white solid. M. p. $83-85^{\circ} \mathrm{C}$. IR $(\mathrm{KBr})$ v $\left(\mathrm{cm}^{-1}\right): 3400,2957,2928,1624,1507,1259 .{ }^{1} \mathrm{H}$ NMR $(250 \mathrm{MHz}$, DMSO- $\left.d_{6}\right): \delta 0.84$ (t, $\left.J=7.3 \mathrm{~Hz}, 3 \mathrm{H}, \mathrm{CH}_{3}\right), 1.22-1.37\left(\mathrm{~m}, 2 \mathrm{H}, \mathrm{CH}_{2}\right.$ ), 1.52-1.66 (m, 2H, $\left.\mathrm{CH}_{2}\right), 2.64-2.74\left(\mathrm{~m}, 2 \mathrm{H}, \mathrm{CH}_{2}\right), 2.95-3.15(\mathrm{~m}$, $\left.2 \mathrm{H}, \mathrm{PhCH}_{2}\right), 3.74\left(\mathrm{~s}, 3 \mathrm{H}, \mathrm{OCH}_{3}\right), 4.07-4.20(\mathrm{~m}, 1 \mathrm{H}, \mathrm{CH}), 5.40(\mathrm{~s}$, $\left.2 \mathrm{H}, \mathrm{CH}_{2} \mathrm{~N}\right), 6.46-6.76\left(\mathrm{~m}, 3 \mathrm{H}, \mathrm{H}_{\text {arom }}+\mathrm{CH}=\right), 6.87(\mathrm{~d}, J=7.8 \mathrm{~Hz}$, $\left.2 \mathrm{H}, \mathrm{H}_{\text {arom }}\right), 7.02\left(\mathrm{~d}, J=7.8 \mathrm{~Hz}, 2 \mathrm{H}, \mathrm{H}_{\text {arom }}\right), 7.12$ (d, J=7.8 Hz, $2 \mathrm{H}$, $\left.\mathrm{H}_{\text {arom }}\right), 7.17-7.39\left(\mathrm{~m}, 5 \mathrm{H}, \mathrm{H}_{\text {arom }}+\mathrm{CH}=\right)$, 7.50-7.64 (m, 2H, $\left.\mathrm{H}_{\text {arom }}\right)$, 7.72-7.79 (m, 1H, $\left.\mathrm{H}_{\text {arom }}\right), 8.07-8.17\left(\mathrm{~m}, 1 \mathrm{H}, \mathrm{H}_{\text {arom }}\right) .{ }^{13} \mathrm{C} \mathrm{NMR}$ $\left(62.9 \mathrm{MHz}, \mathrm{DMSO}-d_{6}\right): \delta 13.6\left(\mathrm{CH}_{3}\right), 21.6\left(\mathrm{CH}_{2}\right), 25.9\left(\mathrm{CH}_{2}\right), 28.9$ $\left(\mathrm{CH}_{2}\right), 37.1,46.4,51.3,57.9,105.9,109.2,112.1,113.9,114.4,121.1$ $\left(\mathrm{C}_{\text {arom }}\right), 121.4,124.9\left(\mathrm{C}_{\text {arom }}\right), 126.7,127.2\left(\mathrm{C}_{\text {arom }}\right), 129.7\left(\mathrm{C}_{\text {arom }}\right), 130.0$ $\left(\mathrm{C}_{\text {arom }}\right), 130.3\left(\mathrm{C}_{\text {arom }}\right), 130.5,131.1,131.7,132.6,133.8,134.5,139.6$, 141.4, 148.7, 149.7, 151.1, $160.5(\mathrm{C}=\mathrm{O}), 164.9(\mathrm{C}=\mathrm{O}), 167.7(\mathrm{C}$ $=\mathrm{O})$. ESI-MS (neg. mode): $m / z=758.25\left([\mathrm{M}-\mathrm{H}],{ }^{35} \mathrm{Cl}\right), 780.23$ $\left([\mathrm{M}-2 \mathrm{H}+\mathrm{Na}]-,{ }^{35} \mathrm{Cl}\right)$. Anal. Calcd for $\mathrm{C}_{41} \mathrm{H}_{38} \mathrm{ClN}_{7} \mathrm{O}_{6}(760.24)$ : C, 64.77; H, 5.04; N, 12.90. Found: C, 64.67; H, 5.15; N, 12.72.

\subsubsection{5. (E)-Pentane-1-sulfonic acid (3-\{2-butyl-5-chloro-3-[2'-(2- trityl-2H-tetrazol-5-yl)-biphenyl-4-ylmethyl]-3H-imidazol-4- yl; acryloyl)amide (26)}

To a suspension of compound 19 (300 mg, $0.42 \mathrm{~mol}$ ), DCC (97 mg, $0.47 \mathrm{mmol}$ ), and DMAP $(52 \mathrm{mg}, 0.42 \mathrm{mmol})$ in anhydrous $\mathrm{CH}_{2} \mathrm{Cl}_{2}$ $(3 \mathrm{~mL})$ was added dropwise a solution of pentane-1-sulfonamide $(156 \mathrm{mg}, 1.03 \mathrm{mmol})$ in anhydrous $\mathrm{CH}_{2} \mathrm{Cl}_{2}(1 \mathrm{~mL})$. The mixture was stirred $18 \mathrm{~h}$ under argon at room temperature and was filtered. The precipitate was washed with cooled EtOAc $(5 \mathrm{~mL})$ and the filtrate was concentrated under reduced pressure. The residue was purified by column chromatography (eluent: $\mathrm{CH}_{2} \mathrm{Cl}_{2} / \mathrm{MeOH}, 97 / 3$ ) to give $162 \mathrm{mg}$ $\left(0.19 \mathrm{mmol}, 45 \%\right.$ yield) of white solid. M. p. $79-81^{\circ} \mathrm{C}$. IR (film) v $\left(\mathrm{cm}^{-1}\right): 3402,3222,3061,2957,2930,1618,1449,1267,1125 .{ }^{1} \mathrm{H}$ NMR (250 MHz, DMSO- $\left.d_{6}\right): \delta 0.71-0.83\left(\mathrm{~m}, 6 \mathrm{H}, 2 \times \mathrm{CH}_{3}\right), 1.08-1.36$ $\left(\mathrm{m}, 6 \mathrm{H}, 3 \times \mathrm{CH}_{2}\right), 1.42-1.68\left(\mathrm{~m}, 4 \mathrm{H}, 2 \times \mathrm{CH}_{2}\right), 3.32-3.41(\mathrm{~m}, 2 \mathrm{H}$, $\left.\mathrm{CH}_{2} \mathrm{~S}\right), 5.31\left(\mathrm{~s}, 2 \mathrm{H}, \mathrm{CH}_{2} \mathrm{~N}\right), 6.75-6.92\left(\mathrm{~m}, 9 \mathrm{H}, \mathrm{H}_{\text {arom }}+\mathrm{CH}=\right), 7.08$ $\left(\mathrm{d}, J=8.1 \mathrm{~Hz}, 2 \mathrm{H}, \mathrm{H}_{\text {arom }}\right), 7.27-7.48\left(\mathrm{~m}, 11 \mathrm{H}, \mathrm{H}_{\text {arom }}+\mathrm{CH}=\right)$, 7.50-7.65 (m, 2H, $\mathrm{H}_{\text {arom }}$ ), 7.80 (br d, $\left.J=7.5 \mathrm{~Hz}, 1 \mathrm{H}, \mathrm{H}_{\text {aroml }}\right), 11.80$ $(\mathrm{s}, 1 \mathrm{H}, \mathrm{NH}) .{ }^{13} \mathrm{C}$ NMR $\left(62.9 \mathrm{MHz}, \mathrm{DMSO}-d_{6}\right): \delta 13.5\left(2 \times \mathrm{CH}_{3}\right), 21.4$ $\left(\mathrm{CH}_{2}\right), 21.5\left(\mathrm{CH}_{2}\right), 22.4\left(\mathrm{CH}_{2}\right), 25.9\left(\mathrm{CH}_{2}\right), 28.6\left(\mathrm{CH}_{2}\right), 29.3\left(\mathrm{CH}_{2}\right)$, $46.1,52.0,82.2,116.8,121.7,125.5\left(\mathrm{CH}_{\text {arom }}\right), 125.6,127.5,127.8$ $\left(\mathrm{CH}_{\text {arom }}\right), 128.3\left(\mathrm{CH}_{\text {arom }}\right), 129.4\left(\mathrm{CH}_{\text {arom }}\right), 129.5\left(\mathrm{CH}_{\text {arom }}\right), 130.3$, $130.5,130.6,130.7,131.0,134.8,139.6,140.8\left(\mathrm{C}_{\text {arom }}\right), 140.8,150.6$, 163.4, 164.4.). ESI-MS (neg. mode): $m / z=838.33\left([\mathrm{M}-\mathrm{H}]-{ }^{35} \mathrm{Cl}\right)$. Anal. Calcd for $\mathrm{C}_{48} \mathrm{H}_{48} \mathrm{ClN}_{7} \mathrm{O}_{3} \mathrm{~S}$ (838.46): C, 68.76; H, 5.77; N, 11.69. Found: C, 68.67; H, 5.61; N, 11.72.

6.1.3.26. (E)- pentane-1-sulfonic acid (3-\{2-butyl-5-chloro-3-[2'-(2Htetrazol-5-yl)biphenyl-4-ylmethyl]-3H-imidazol-4-yl\}acryloyl)-amide (27)

To a solution of compound $\mathbf{2 6}(46 \mathrm{mg}, 0.05 \mathrm{mmol})$ in THF $(3 \mathrm{~mL})$ was added a $2 \mathrm{~N}$ aqueous $\mathrm{HCl}$ solution $(3 \mathrm{~mL})$. The mixture was stirred at room temperature for $8 \mathrm{~h}$. EtOAc $(30 \mathrm{~mL})$ was added and the organic phase was washed with water $(3 \times 15 \mathrm{~mL})$, dried $\left(\mathrm{MgSO}_{4}\right)$, and the solvent was evaporated. The residue was purified by column chromatography (eluent: $\mathrm{CH}_{2} \mathrm{Cl}_{2} / \mathrm{MeOH}, 90 / 10$ ) to give $25 \mathrm{mg}$ $(0.04 \mathrm{mmol}, 76 \%$ yield $)$ of white solid. M. p. $142-144^{\circ} \mathrm{C}$. IR ( $\left.\mathrm{KBr}\right)$ v $\left(\mathrm{cm}^{-1}\right): 3435,2957,2928,1618,1459,1341,1266,1125 .{ }^{1} \mathrm{H}$ NMR $\left(250 \mathrm{MHz}, \quad\right.$ DMSO- $\left.d_{6}\right): \quad \delta \quad 0.77-0.87 \quad\left(\mathrm{~m}, \quad 6 \mathrm{H}, \quad 2 \times \mathrm{CH}_{3}\right)$,
1.17-1.38 (m, 6H, 3 $\left.\times \mathrm{CH}_{2}\right), 1.47-1.70\left(\mathrm{~m}, 4 \mathrm{H}, 2 \times \mathrm{CH}_{2}\right), 2.58-2.70$ (m, 2H, $\left.\mathrm{CH}_{2}\right), 3.26-3.37\left(\mathrm{~m}, 2 \mathrm{H}, \mathrm{CH}_{2} \mathrm{~S}\right), 5.37\left(\mathrm{~s}, 2 \mathrm{H}, \mathrm{CH}_{2} \mathrm{~N}\right), 6.70$ $(\mathrm{d}, J=16.0 \mathrm{~Hz}, 1 \mathrm{H}, \mathrm{CH}=), 6.92\left(\mathrm{~d}, J=7.8 \mathrm{~Hz}, 2 \mathrm{H}, \mathrm{H}_{\text {arom }}\right), 7.10(\mathrm{~d}$, $\left.J=7.8 \mathrm{~Hz}, 2 \mathrm{H}, \mathrm{H}_{\text {arom }}\right), 7.36(\mathrm{~d}, J=16.0 \mathrm{~Hz}, 1 \mathrm{H}, \mathrm{CH}=), 7.42-7.69(\mathrm{~m}$, $\left.4 \mathrm{H}, \mathrm{H}_{\text {arom }}\right) \cdot{ }^{13} \mathrm{C}$ NMR $\left(62.9 \mathrm{MHz}, \mathrm{DMSO}-d_{6}\right): \delta 13.6\left(2 \times \mathrm{CH}_{3}\right), 21.5$ $\left(\mathrm{CH}_{2}\right), 21.6\left(\mathrm{CH}_{2}\right), 22.5\left(\mathrm{CH}_{2}\right), 25.9\left(\mathrm{CH}_{2}\right), 28.9\left(\mathrm{CH}_{2}\right), 29.5\left(\mathrm{CH}_{2}\right)$, $46.2\left(\mathrm{CH}_{2}\right), 52.0\left(\mathrm{CH}_{2}\right), 118.8,121.8,125.5\left(\mathrm{CH}_{\text {arom }}\right), 126.3,126.5$, $127.5,129.4\left(\mathrm{CH}_{\text {arom }}\right), 129.8,130.4,130.5,135.0,139.5,140.4,150.4$, 156.7, $165.3(\mathrm{C}=\mathrm{O})$. ESI-MS (neg. mode): $m / z=594.20\left([\mathrm{M}-\mathrm{H}]^{-}\right.$, ${ }^{35} \mathrm{Cl}$ ). Anal. Calcd for $\mathrm{C}_{29} \mathrm{H}_{34} \mathrm{ClN}_{7} \mathrm{O}_{3} \mathrm{~S}$ (596.14): C, 58.43; H, 5.75; N, 16.45. Found: C, 58.37; H, 5.51; N, 16.32 .

\subsubsection{5-[4'-(2-butyl-4-chloro-5-dodecyloxymethyl-imidazol-1- ylmethyl)biphenyl-2-yl]-2-trityl-2H-tetrazole (28)}

To an ice-cooled solution of compound $1(150 \mathrm{mg}, 0.23 \mathrm{mmol})$ in anhydrous THF $(2 \mathrm{~mL})$ under argon was added $60 \% \mathrm{NaH}(17 \mathrm{mg}$, $0.43 \mathrm{mmol}$ ). The suspension was stirred at room temperature for $30 \mathrm{~min}$, followed by the addition of dodecylmethanesulfonate $(56 \mathrm{mg}$, $0.22 \mathrm{mmol}$ ). The suspension was stirred at reflux for $24 \mathrm{~h}$ under argon. The suspension was cooled $\left(0{ }^{\circ} \mathrm{C}\right)$ and water $(2 \mathrm{~mL})$ was added, followed by EtOAc $(60 \mathrm{~mL})$. The organic phase was washed with water $(3 \times 30 \mathrm{~mL})$, dried $\left(\mathrm{MgSO}_{4}\right)$, and the solvent was evaporated. The residue was purified by column chromatography (eluent: cyclohexane/ EtOAc, $90 / 10)$ to give $85 \mathrm{mg}(0.10 \mathrm{mmol}, 45 \%$ yield $)$ of colorless liquid. IR (film) $v\left(\mathrm{~cm}^{-1}\right): 2926,2854,1447,1250,758,745,698 .{ }^{1} \mathrm{H}$ NMR $\left(250 \mathrm{MHz}, \mathrm{CDCl}_{3}\right): \delta 0.81-0.91\left(\mathrm{~m}, 6 \mathrm{H}, 2 \times \mathrm{CH}_{3}\right), 1.22-1.36$ $\left(\mathrm{m}, 20 \mathrm{H}, 10 \times \mathrm{CH}_{2}\right), 1.43-1.71\left(\mathrm{~m}, 4 \mathrm{H}, 2 \times \mathrm{CH}_{2}\right), 2.50\left(\mathrm{~m}, 2 \mathrm{H}, \mathrm{CH}_{2}\right)$, $3.30\left(\mathrm{t}, J=6.6 \mathrm{~Hz}, 2 \mathrm{H}, \mathrm{CH}_{2} \mathrm{O}\right), 4.16\left(\mathrm{~s}, 2 \mathrm{H}, \mathrm{CH}_{2} \mathrm{O}\right), 5.05(\mathrm{~s}, 2 \mathrm{H}$, $\left.\mathrm{CH}_{2} \mathrm{~N}\right), 6.74\left(\mathrm{~d}, J=8.0 \mathrm{~Hz}, 2 \mathrm{H}, \mathrm{H}_{\text {arom }}\right), 6.90-6.97\left(\mathrm{~m}, 6 \mathrm{H}, \mathrm{H}_{\text {arom }}\right), 7.11$ $\left(\mathrm{d}, J=8.0 \mathrm{~Hz}, 2 \mathrm{H}, \mathrm{H}_{\text {arom }}\right), 7.21-7.38\left(\mathrm{~m}, 10 \mathrm{H}, \mathrm{H}_{\text {arom }}\right), 7.42-7.53(\mathrm{~m}$, $\left.2 \mathrm{H}, \mathrm{H}_{\text {arom }}\right), 7.93\left(\mathrm{~m}, 1 \mathrm{H}, \mathrm{H}_{\text {arom }}\right) .{ }^{13} \mathrm{C} \mathrm{NMR}\left(62.9 \mathrm{MHz}, \mathrm{CDCl}_{3}\right): \delta 13.9$ $\left(\mathrm{CH}_{3}\right), 14.26\left(\mathrm{CH}_{3}\right), 22.6\left(\mathrm{CH}_{2}\right), 22.8\left(\mathrm{CH}_{2}\right), 26.3\left(\mathrm{CH}_{2}\right), 26.8\left(\mathrm{CH}_{2}\right)$, $29.5\left(\mathrm{CH}_{2}\right), 29.6\left(\mathrm{CH}_{2}\right), 29.7\left(\mathrm{CH}_{2}\right), 29.8\left(4 \times \mathrm{CH}_{2}\right), 29.9\left(\mathrm{CH}_{2}\right), 32.1$ $\left(\mathrm{CH}_{2}\right), 47.3\left(\mathrm{CH}_{2} \mathrm{~N}\right), 60.6\left(\mathrm{CH}_{2} \mathrm{O}\right), 70.0\left(\mathrm{CH}_{2} \mathrm{O}\right), 83.0122 .7,125.4$ $\left(\mathrm{CH}_{\text {arom }}\right), 126.4,127.8\left(\mathrm{CH}_{\text {arom }}\right), 127.9,128.4\left(\mathrm{CH}_{\text {arom }}\right), 130.0$ $\left(\mathrm{CH}_{\text {arom }}\right), 130.1,130.4\left(\mathrm{CH}_{\text {arom }}\right), 130.5,130.9,134.6,141.1,141.5$ $\left(\mathrm{C}_{\text {arom }}\right), 148.6,164,1$. ESI-MS (pos. mode): $m / z=833.47\left([\mathrm{M}+\mathrm{H}]^{+}\right.$, ${ }^{35} \mathrm{Cl}$ ). Anal. Calcd for $\mathrm{C}_{53} \mathrm{H}_{61} \mathrm{ClN}_{6} \mathrm{O}$ (833.54): C, 76.37; H, 7.38; N, 10.08. Found: C, 67.16; H, 7.44; N, 10.24.

\subsubsection{5-[4'-(2-butyl-4-chloro-5-dodecyloxymethyl-imidazol-1- ylmethyl)-biphenyl-2-yl]-2H-tetrazole (29)}

To a solution of compound $28(59 \mathrm{mg}, 0.07 \mathrm{mmol})$ in THF $(3 \mathrm{~mL})$ was added a $2 \mathrm{~N}$ aqueous $\mathrm{HCl}$ solution $(3 \mathrm{~mL})$. The solution was stirred at room temperature for $7 \mathrm{~h}$, EtOAc $(30 \mathrm{~mL})$ was added, the organic phase was washed with water $(3 \times 15 \mathrm{~mL})$, dried $\left(\mathrm{MgSO}_{4}\right)$, and the solvent was evaporated. The residue was purified by column chromatography (eluent: $\left.\mathrm{CH}_{2} \mathrm{Cl}_{2} / \mathrm{MeOH}, 99 / 1\right)$ to give $33 \mathrm{mg}(0.05 \mathrm{mmol}$, $79 \%$ yield) of colorless liquid. IR (film) $v\left(\mathrm{~cm}^{-1}\right): 3436,2925,1640$, $1465,1253 .{ }^{1} \mathrm{H}$ NMR $\left(250 \mathrm{MHz}, \mathrm{DMSO}-d_{6}\right): \delta 0.75-0.89(\mathrm{~m}, 6 \mathrm{H}$, $\left.2 \times \mathrm{CH}_{3}\right), 1.11-1.54\left(\mathrm{~m}, 24 \mathrm{H}, 12 \times \mathrm{CH}_{2}\right), 2.48\left(\mathrm{~m}, 2 \mathrm{H}, \mathrm{CH}_{2}\right), 3.30(\mathrm{t}$, $\left.J=6.3 \mathrm{~Hz}, 2 \mathrm{H}, \mathrm{CH}_{2} \mathrm{O}\right), 4.29\left(\mathrm{~s}, 2 \mathrm{H}, \mathrm{CH}_{2} \mathrm{O}\right), 5.18\left(\mathrm{~s}, 2 \mathrm{H}, \mathrm{CH}_{2} \mathrm{~N}\right), 7.00$ (d, $\left.J=8.2 \mathrm{~Hz}, 2 \mathrm{H}, \mathrm{H}_{\text {arom }}\right), 7.07$ (d, $\left.J=8.2 \mathrm{~Hz}, 2 \mathrm{H}, \mathrm{H}_{\text {arom }}\right), 7.46-7.71$ $\left(\mathrm{m}, 4 \mathrm{H}, \mathrm{H}_{\text {arom }}\right) \cdot{ }^{13} \mathrm{C}$ NMR $\left(62.9 \mathrm{MHz}, \mathrm{DMSO}-d_{6}\right): \delta 13.6\left(\mathrm{CH}_{3}\right), 13.9$ $\left(\mathrm{CH}_{3}\right), 21.6\left(\mathrm{CH}_{2}\right), 22.0\left(\mathrm{CH}_{2}\right), 25.5\left(\mathrm{CH}_{2}\right), 28.8\left(\mathrm{CH}_{2}\right), 28.6\left(\mathrm{CH}_{2}\right)$, $28.7\left(\mathrm{CH}_{2}\right), 28.8\left(5 \times \mathrm{CH}_{2}\right), 28.9\left(\mathrm{CH}_{2}\right), 29.0\left(\mathrm{CH}_{2}\right), 31.2\left(\mathrm{CH}_{2}\right), 46.5$ $\left(\mathrm{CH}_{2} \mathrm{~N}\right), 59.7\left(\mathrm{CH}_{2} \mathrm{O}\right), 69.0\left(\mathrm{CH}_{2} \mathrm{O}\right), 122.5,123.6,126.2\left(\mathrm{CH}_{\text {arom }}\right)$, 127.0, 127.8, $129.0\left(\mathrm{CH}_{\text {arom }}\right), 130.4,130.5,130.9,135.9,138.4,141.0$, 147.9. ESI-MS (neg. mode): $\left.m / z=589.34([\mathrm{M}-\mathrm{H}]]^{-},{ }^{35} \mathrm{Cl}\right)$. Anal. Calcd for $\mathrm{C}_{34} \mathrm{H}_{47} \mathrm{ClN}_{6} \mathrm{O}$ (591.23): C, 69.07; H, 8.01; N, 14.21. Found: $\mathrm{C}$, $68.99 ; \mathrm{H}, 8.16 ; \mathrm{N}, 13.91$. 


\subsubsection{Molecular docking}

The docking process was carried out with AutoDock v4.2 [54]. The three dimensional structure of PPAR $\gamma$ was retrieved from the Protein Data Bank (PDB code: 2PRG). The binding site was located on the first chain (A) by the position of the native ligand, rosiglitazone. Both the protein and the ligands were prepared by adding polar hydrogen atoms and partial charges with the assistance of AutoDockTools 1.5.6 [55]. A pre-calculated three-dimensional energy grid of equally spaced discrete points was generated prior to the docking using the program AutoGrid [54]. The grid box $(29 \AA \times 29 \AA \times 29 \AA)$ contains the PPAR- $\gamma$ binding pocket, i.e. entrance, arm I, and arm II, as defined by Zoete et al. [43], and is centered on the C $\alpha$ atom of Cys285. The distance between two grid points was set to $0.375 \AA$. The grid map files were calculated by AutoGrid for all ligand atom types. For conformational search, Lamarckian Genetic Algorithm, which combines a local search and a genetic algorithm to provide both efficient global space coverage and local search optimization, was chosen. During the process, the protein was held rigid. The population size was set to 300 , the maximum number of energy evaluations was set to $500,000,000$, the maximum number of generations was 50,000 , the mutation rate was 0.02 and the crossover rate was 0.8 . The remaining parameters were set as their default values. For each ligand, 30 independent runs were performed. The figures were prepared with Pymol [56] and LigPlot+ [44].

\subsection{Biological evaluation}

\subsubsection{Evaluation of the transactivation of PPAR- $\gamma$}

\subsubsection{Cell culture and reagents}

MCF-7 human breast cancer cell line was obtained from American Type Culture Collection (Rockville, MD). Cells were grown at $37^{\circ} \mathrm{C}$ under $5 \% \mathrm{CO}_{2}$, in phenol red Dulbecco's modified Eagle medium. These media were supplemented with $10 \%$ fetal calf serum and $2 \mathrm{mM}$ l-glutamine. Compounds were dissolved at $50 \mathrm{mM}$ in sterile DMSO and following dilutions were carried out in $\mathrm{EtOH}$. All these compounds were stored frozen at $-20^{\circ} \mathrm{C}$. DMEM, Ethanol $(\mathrm{EtOH})$, dimethylsulfoxide (DMSO), fetal calf serum (FCS), L-glutamine- were purchased from Sigma-Aldrich (Lyon, France).

\subsubsection{Transient transfection assays}

MCF-7 cells were seeded in 6-well plates at the density of $2 \times 10^{5}$ cells $/ \mathrm{mL}$ in $2 \mathrm{~mL}$, and allowed to adhere for $24 \mathrm{~h}$. Cells were transfected with $\mathrm{pPPRE}_{3}$-tk-luc reporter $(1 \mu \mathrm{g} / \mathrm{well})$ and pCMV- $\beta$-galactosidase ( $\beta$-Gal) $(0.6 \mu \mathrm{g} /$ well $)$, as an internal control plasmid, in the presence of a human PPAR- $\gamma$ expression vector $(2 \mu \mathrm{g} /$ well). Transfections were performed using Exgen 500 (Euromedex, Souffelweyersheim, France) according to the manufacturer's protocol. $24 \mathrm{~h}$ after transfection, cells were treated with $10 \mu \mathrm{M}$ of compound for $24 \mathrm{~h}$ in fresh DMEM supplemented with $10 \%$ FCS stripped in dextran-coated charcoal and $2 \mathrm{mM}$ of L-glutamine. Control wells were treated with control solvent. In each sample, luciferase activity was measured by using the Bright-Glo Luciferase Assay System (Promega, Charbonnières, France). $\beta$-Gal activity was measured using the $\beta$-Galactosidase Enzyme Assay System (Promega, Charbonnières, France). Luciferase activity was detected using a luminometer VictorX3 (Perkin Elmer, Villebon-sur-Yvette, France) and normalized with respect to $\beta$-Gal activity.

\subsubsection{Evaluation of $A T_{1}$ blocking}

Early passages (P3-4) vascular smooth muscle cells (VSMC) cultures prepared from enzymatically-digested aorta from rats were used for in vitro experiments. Cells were cultured in DMEM supplemented with $10 \%$ fetal bovine serum (FBS) and antibiotics in a humidified atmosphere with $5 \% \mathrm{CO}_{2}$. For calcium mobilization assay, cells were cultured in 96-well plates (80-90\% confluence) and loaded with the calcium probe Fura-2/AM ( $3 \mu \mathrm{M}$, Sigma) in Hanks balanced salt solution with $2.5 \mathrm{mM} \mathrm{CaCl}_{2}, 1 \mathrm{mM} \mathrm{MgCl}_{2}, 10 \mathrm{mM}$ HEPES, $0.5 \%$ BSA,

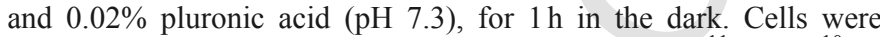
washed twice with the same buffer, and molecules $\left(10^{-11} \mathrm{M}, 10^{-10} \mathrm{M}\right.$, $10^{-9} \mathrm{M}, 10^{-8} \mathrm{M}, 10^{-7} \mathrm{M}, 10^{-6} \mathrm{M}$, and $10^{-5} \mathrm{M}$ ) were added for $20 \mathrm{~min}$. Angiotensin II $\left(10^{-9} \mathrm{M}\right)$ was then added and calcium concentration measured using a dual excitation at $340 / 380 \mathrm{~nm}$ with single emission at $510 \mathrm{~nm}$ with a FlexStation ${ }^{\circledR}$ III scanning fluorometer (Molecular Devices Ltd., Wokingham, UK). Softmax Pro (Molecular Devices) software was used for data analysis. Mean, SEM (standard error of the mean) and $\mathrm{IC}_{50}$ (median inhibitive concentration) were calculated with GraphPad Prism software.

\subsubsection{Evaluation of the antihypertensive activity of compound 5 on} rats

The experiments were conducted on 3-4 month-old male normotensive outbred Wistar rats $(\mathrm{Rj} / \mathrm{Han}$ : Wi, Janvier, France). Briefly, animals were anesthetized with sodium pentobarbitone $(60 \mathrm{mg} / \mathrm{kg}$, intraperitoneally), intubated and mechanically ventilated with room air. A polyethylene cannula was introduced into the right femoral artery and connected to a low volume, strain-gauge transducer for measurement of blood pressure and heart rate. Anesthesia was maintained by continuous infusion of sodium pentobarbitone $(0.25 \mathrm{~mL} / \mathrm{h} ; 20 \mathrm{mg} / \mathrm{kg}$ per $\mathrm{h}$ ) through a silicone catheter introduced into the right femoral vein. The substances (Angiotensin II, $10^{-10} \mathrm{~mol} / \mathrm{kg}$; losartan and compound $5,6.10^{-5} \mathrm{~mol} / \mathrm{kg}$ ) were administered through a second silicone catheter (left femoral vein, volume of $500 \mu \mathrm{L} / \mathrm{kg}$ ). Angiotensin II was administered before and after losartan or compound 5. Angiotensin II induced a rapid and transient increase in blood pressure and heart rate which was blunted after losartan or compound $\mathbf{5}$ injection. For each injection of AngII, variation in mean arterial pressure was calculated as the difference between the maximal (after AngII) and baseline (just before AngII) pressure values. Experiments were performed in accordance with the European Community guidelines (2010/63/EU) for the use of experimental animals.

\section{Acknowledgments}

The authors thank B. Fernette and F. Dupire for spectroscopic measurements, A. Kleinclauss for in vitro cell cultures, the MENRT for a fellowship to MM, and the Lorraine Regional Council (Metz, France) and the Pharmacolor Association (Nancy, France) for a fellowship to SF.

\section{Appendix A. Supplementary data}

Supplementary data related to this article can be found at https:// doi.org/10.1016/j.ejmech.2018.08.082.

\section{References}

[1] R. Morphy, Z. Rankovic, Designed multiple ligands. An emerging drug discovery paradigm, J. Med. Chem. 48 (2005) 6523-6543, https://doi.org/10.1021/ jm058225d. 
[2] G.R. Zimmermann, J. Lehár, C.T. Keith, Multi-target therapeutics: when the whole is greater than the sum of the parts, Drug Discov. Today 12 (2007) 34-42, https://doi.org/10.1016/j.drudis.2006.11.008.

[3] R. Morphy, Z. Rankovic, Designing multiple ligands - medicinal chemistry strategies and challenges, Curr. Pharmaceut. Des. 15 (2009) 587-600, https://doi. org/10.2174/138161209787315594.

[4] J.L. Medina-Franco, M.A. Giulianotti, G.S. Welmaker, R.A. Houghten, Shifting from the single to the multitarget paradigm in drug discovery, Drug Discov. Today 18 (2013) 495-501, https://doi.org/10.1016/j.drudis.2013.01.008.

[5] J.-U. Peters, Polypharmacology - foe or friend?, J. Med. Chem. 56 (2013) 8955-8971, https://doi.org/10.1021/jm400856t.

[6] A. Anighoro, J. Bajorath, G. Rastelli, Polypharmacology: challenges and opportunities in drug discovery, J. Med. Chem. 57 (2014) 7874-7887, https://doi.org/ $10.1021 / \mathrm{jm} 5006463$.

[7] K. Nepali, S. Sharma, M. Sharma, P.M.S. Bedi, K.L. Dhar, Rational approaches, design strategies, structure activity relationship and mechanistic insights for anticancer hybrids, Eur. J. Med. Chem. 77 (2014) 422-487, https://doi.org/10.1016/ j.ejmech.2014.03.018.

[8] C. Lecoutey, D. Hedou, T. Freret, P. Giannoni, F. Gaven, M. Since, V. Bouet, C. Ballandonne, S. Corvaisier, A.M. Fréon, S. Mignani, T. Cresteil, M. Boulouard, S. Claeysen, C. Rochais, P. Dallemagne, Design of donecopride, a dual serotonin subtype 4 receptor agonist/acetylcholinesterase inhibitor with potential interest for Alzheimer's disease treatment, Proc. Natl. Acad. Sci. Unit. States Am. 111 (2014) E3825-E3830, https://doi.org/10.1073/pnas.1410315111.

[9] C. Rochais, C. Lecoutey, F. Gaven, P. Giannoni, K. Hamidouche, D. Hedou, E. Dubost, D. Genest, S. Yahiaoui, T. Freret, V. Bouet, F. Dauphin, J. Sopkova de Oliveira Santos, C. Ballandonne, S. Corvaisier, A. Malzert-Fréon, R. Legay, M. Boulouard, S. Claeysen, P. Dallemagne, Novel multitarget-directed ligands (MTDLs) with acetylcholinesterase (AChE) inhibitory and serotonergic subtype 4 receptor (5-HT4R) agonist activities as potential agents against Alzheimer's disease: the design of donecopride, J. Med. Chem. 58 (2015) 3172-3187, https:// doi.org/10.1021/acs.jmedchem.5b00115.

[10] S.-S. Xie, J.-S. Lan, X.-B. Wang, N. Jiang, G. Dong, Z.-R. Li, K.D.G. Wang, P.-P. Guo, L.-Y. Kong, Multifunctional tacrine-trolox hybrids for the treatment of Alzheimer's disease with cholinergic, antioxidant, neuroprotective and hepatoprotective properties, Eur. J. Med. Chem. 93 (2015) 42-50, https://doi.org/10. 1016/j.ejmech.2015.01.058.

[11] W.J. Geldenhuys, M.B.H. Youdim, R.T. Carroll, C.J. Van der Schyf, The emergence of designed multiple ligands for neurodegenerative disorders, Prog. Neurobiol. 94 (2011) 347-359, https://doi.org/10.1016/j.pneurobio.2011.04.010.

[12] P.J. Miranda, R.A. DeFronzo, R.M. Califf, J.R. Guyton, Metabolic syndrome definition, pathophysiology, and mechanisms, Am. Heart J. 149 (2005) 33-45, https://doi.org/10.1016/j.ahj.2004.07.013.

[13] S.M. Grundy, Drug therapy of the metabolic syndrome: minimizing the emerg ing crisis in polypharmacy, Nat. Rev. Drug Discov. 5 (2006) 295-309, https:// doi.org/10.1038/nrd2005.

[14] T.W. Kurtz, M. Pravenec, Antidiabetic mechanisms of angiotensin-converting enzyme inhibitors and angiotensin II receptor antagonists: beyond the renin-angiotensin system, J. Hypertens. 22 (2004) 2253-2261.

[15] M. Schupp, Angiotensin type 1 receptor blockers induce peroxisome proliferator-activated receptor- activity, Circulation 109 (2004) 2054-2057, https://doi. org/10.1161/01.CIR.0000127955.36250.65.

[16] S.C. Benson, H.A. Pershadsingh, C.I. Ho, A. Chittiboyina, P. Desai, M. Pravenec, N. Qi, J. Wang, M.A. Avery, T.W. Kurtz, Identification of telmisartan as a unique angiotensin II receptor antagonist with selective PPAR -modulating activity, Hypertension 43 (2004) 993-1002, https://doi.org/10.1161/01.HYP. 0000123072.34629 .57$.

[17] T.W. Kurtz, Treating the metabolic syndrome: telmisartan as a peroxisome proliferator-activated receptor-gamma activator, Acta Diabetol. 42 (2005) s9-s16, https://doi.org/10.1007/s00592-005-0176-0.

[18] Y. Amano, T. Yamaguchi, K. Ohno, T. Niimi, M. Orita, H. Sakashita, M. Takeuchi, Structural basis for telmisartan-mediated partial activation of PPAR gamma, Hypertens. Res. 35 (2012) 715-719, https://doi.org/10.1038/hr.2012.17.

[19] Y. Wang, S. Qiao, D.-W. Han, X.-R. Rong, Y.-X. Wang, J. Xue, J. Yang, Telmisartan improves insulin resistance: a meta-analysis, Am. J. Therapeut. (2018) https://doi.org/10.1097/MJT.0000000000000733, Publish Ahead of Print.

[20] C.S. Mizuno, A.G. Chittiboyina, F.H. Shah, A. Patny, T.W. Kurtz, H.A. Pershadsingh, R.C. Speth, V.T. Karamyan, P.B. Carvalho, M.A. Avery, Design, synthesis, and docking studies of novel benzimidazoles for the treatment of metabolic syndrome, J. Med. Chem. 53 (2010) 1076-1085, https://doi.org/10. $1021 / j m 901272 \mathrm{~d}$

[21] A. Casimiro-Garcia, G.F. Filzen, D. Flynn, C.F. Bigge, J. Chen, J.A. Davis, D.A Dudley, J.J. Edmunds, N. Esmaeil, A. Geyer, R.J. Heemstra, M. Jalaie, J.F. Ohren, R. Ostroski, T. Ellis, R.P. Schaum, C. Stoner, Discovery of a series of imidazo[4,5-b]pyridines with dual activity at angiotensin II type 1 receptor and peroxisome proliferator-activated receptor- $\gamma$, J. Med. Chem. 54 (2011) 4219-4233, https://doi.org/10.1021/jm200409s.
[22] A. Casimiro-Garcia, R.J. Heemstra, C.F. Bigge, J. Chen, F.A. Ciske, J.A. Davis, T. Ellis, N. Esmaeil, D. Flynn, S. Han, M. Jalaie, J.F. Ohren, N.A. Powell, Design, synthesis, and evaluation of imidazo[4,5-c]pyridin-4-one derivatives with dual activity at angiotensin II type 1 receptor and peroxisome proliferator-activated receptor- $\gamma$, Bioorg. Med. Chem. Lett 23 (2013) 767-772, https://doi.org/ 10.1016/j.bmcl.2012.11.088.

[23] Y. Lamotte, N. Faucher, J. Sançon, O. Pineau, S. Sautet, M.-H. Fouchet, V. Beneton, J.-J. Tousaint, Y. Saintillan, N. Ancellin, E. Nicodeme, D. Grillot, P. Martres, Discovery of novel indazole derivatives as dual angiotensin II antagonists and partial PPAR $\gamma$ agonists, Bioorg. Med. Chem. Lett 24 (2014) 1098-1103, https://doi.org/10.1016/j.bmcl.2014.01.004.

[24] A.G. Chittiboyina, C.S. Mizuno, P.V. Desai, A. Patny, T.W. Kurtz, H.A. Pershadsingh, R.C. Speth, V. Karamyan, M.A. Avery, Design, synthesis, and docking studies of novel telmisartan-glitazone hybrid analogs for the treatment of metabolic syndrome, Med. Chem. Res. 18 (2009) 589-610, https://doi.org/10. 1007/s00044-008-9152-x.

[25] G. García, M. Rodríguez-Puyol, R. Alajarín, I. Serrano, P. Sánchez-Alonso, M Griera, J.J. Vaquero, D. Rodríguez-Puyol, J. Álvarez-Builla, M.L.

Díez-Marqués, Losartan-antioxidant hybrids: novel molecules for the prevention of hypertension-induced cardiovascular damage, J. Med. Chem. 52 (2009) 7220-7227, https://doi.org/10.1021/jm9003957.

[26] G. García, I. Serrano, P. Sánchez-Alonso, M. Rodríguez-Puyol, R. Alajarín, M. Griera, J.J. Vaquero, D. Rodríguez-Puyol, J. Álvarez-Builla, M.L.

Díez-Marqués, New losartan-hydrocaffeic acid hybrids as antihypertensive-antioxidant dual drugs: ester, amide and amine linkers, Eur. J. Med. Chem. 50 (2012) 90-101, https://doi.org/10.1016/j.ejmech.2012.01.043.

[27] M.C. Breschi, V. Calderone, M. Digiacomo, M. Macchia, A. Martelli, E. Martinotti, F. Minutolo, S. Rapposelli, A. Rossello, L. Testai, A. Balsamo, New no-releasing pharmacodynamic hybrids of losartan and its active metabolite: design, synthesis, and biopharmacological properties, J. Med. Chem. 49 (2006) 2628-2639, https://doi.org/10.1021/jm0600186.

[28] C.R. Ganellin, A. Fkyerat, B. Bang-Andersen, S. Athmani, W. Tertiuk, M. Garbarg, X. Ligneau, J.-C. Schwartz, A novel series of (Phenoxyalkyl)imidazoles as potent H3-Receptor histamine antagonists, J. Med. Chem. 39 (1996) 3806-3813, https://doi.org/10.1021/jm9601381.

[29] J.-W. Huang, Peroxisome proliferator-activated receptor -independent ablation of cyclin D1 by thiazolidinediones and their derivatives in breast cancer cells, Mol. Pharmacol. 67 (2005) 1342-1348, https://doi.org/10.1124/mol.104.007732.

[30] V. Santagada, F. Fiorino, E. Perissutti, B. Severino, S. Terracciano, C.E. Teixeira, G. Caliendo, A convenient synthesis by microwave irradiation of an active metabolite (EXP-3174) of losartan, Tetrahedron Lett. 44 (2003) 1149-1152, https://doi.org/10.1016/S0040-4039(02)02835-6.

[31] K. Rikimaru, T. Wakabayashi, H. Abe, H. Imoto, T. Maekawa, O. Ujikawa, K. Murase, T. Matsuo, M. Matsumoto, C. Nomura, H. Tsuge, N. Arimura, K. Kawakami, J. Sakamoto, M. Funami, C.D. Mol, G.P. Snell, K.A. Bragstad, B.-C. Sang, D.R. Dougan, T. Tanaka, N. Katayama, Y. Horiguchi, Y. Momose, A new class of non-thiazolidinedione, non-carboxylic-acid-based highly selective peroxisome proliferator-activated receptor (PPAR) $\gamma$ agonists: design and synthesis of benzylpyrazole acylsulfonamides, Bioorg. Med. Chem. 20 (2012) 714-733, https://doi.org/10.1016/j.bmc.2011.12.008.

[32] R. Jeon, S. Park, Synthesis and biological activity of Benzoxazole containing thiazolidinedione derivatives, Arch Pharm. Res. (Seoul) 27 (2004) 1099-1105, https://doi.org/10.1007/BF02975111.

[33] J.E. Cobb, S.G. Blanchard, E.G. Boswell, K.K. Brown, P.S. Charifson, J.P. Cooper, J.L. Collins, M. Dezube, B.R. Henke, E.A. Hull-Ryde, D.H. Lake, J.M. Lenhard, William Oliver, J. Oplinger, M. Pentti, D.J. Parks, K.D. Plunket, W.-Q. Tong, N-(2-Benzoylphenyl)-1-tyrosine PPAR $\gamma$ agonists. 3. Structure-Activity relationship and optimization of the N-Aryl substituent, J. Med. Chem. 41 (1998) 5055-5069, https://doi.org/10.1021/jm980414r.

[34] C. Fruit, P. Mueller, Intramolecular asymmetric amidations of sulfonamides and sulfamates catalyzed by chiral dirhodium (II) complexes, Helv. Chim. Acta 87 (2004) 1607-1615.

[35] M. Schupp, L.D. Lee, N. Frost, S. Umbreen, B. Schmidt, T. Unger, U. Kintscher, Regulation of peroxisome proliferator-activated receptor activity by losartan metabolites, Hypertension 47 (2006) 586-589, https://doi.org/10.1161/01.HYP $0000196946.79674 .8 \mathrm{~b}$.

[36] M. Paramanik, R. Singh, S. Mukhopadhyay, S.K. Ghosh, Catalytic nucleophilic fluorination by an imidazolium ionic liquid possessing trialkylphosphine oxide functionality, J. Fluorine Chem. 178 (2015) 47-55, https://doi.org/10.1016/j. jfluchem.2015.06.022.

[37] M. Meyer, S. Kuntz, I. Grillier-Vuissoz, H. Martin, L. Richert, S. Flament, Y. Chapleur, M. Boisbrun, Synthesis and anti-proliferative activity of new biphenyle-benzylidenethiazolidine- 2,4-dione bis-adducts containing various heterocyclic cores, Lett. Drug Des. Discov. 11 (2014) 256-264, https://doi.org/10. 2174/15701808113106660080.

[38] M. Journet, D. Cai, L.M. DiMichele, R.D. Larsen, Highly efficient synthesis of $\alpha, \beta$-acetylenic aldehydes from terminal alkynes using DMF as the formylating 
reagent, Tetrahedron Lett. 39 (1998) 6427-6428, https://doi.org/10.1016/ S0040-4039(98)01352-5.

[39] M. Journet, D. Cai, J.J. Kowal, R.D. Larsen, Highly efficient and mild synthesis of variously 5-substituted-4-carbaldehyde-1,2,3-triazole derivatives, Tetrahedron Lett. 42 (2001) 9117-9118, https://doi.org/10.1016/S0040-4039(01)01923-2.

[40] E. Balducci, L. Bellucci, E. Petricci, M. Taddei, A. Tafi, Microwave-assisted intramolecular huisgen cycloaddition of azido alkynes derived from $\alpha$-amino acids, J. Org. Chem. 74 (2009) 1314-1321, https://doi.org/10.1021/jo802463r.

[41] B.R. Henke, S.G. Blanchard, M.F. Brackeen, K.K. Brown, J.E. Cobb, J.L. Collins, Harrington W. Wallace, M.A. Hashim, E.A. Hull-Ryde, I. Kaldor, S.A. Kliewer, D.H. Lake, L.M. Leesnitzer, J.M. Lehmann, J.M. Lenhard, L.A. Orband-Miller, J.F. Miller, A. Mook Robert, S.A. Noble, William Oliver, D.J. Parks, K.D. Plunket, J.R. Szewczyk, T.M. Willson, N-(2-Benzoylphenyl)-l-tyrosine PPAR $\gamma$ agonists. 1. Discovery of a novel series of potent antihyperglycemic and antihyperlipidemic agents, J. Med. Chem. 41 (1998) 5020-5036, https://doi. org/10.1021/jm9804127.

[42] D.J. Carini, J.V. Duncia, P.E. Aldrich, A.T. Chiu, A.L. Johnson, M.E. Pierce, W.A. Price, J.B. Santella, G.J. Wells, Nonpeptide angiotensin II receptor antagonists: the discovery of a series of N-(biphenylylmethyl)imidazoles as potent, orally active antihypertensives, J. Med. Chem. 34 (1991) 2525-2547, https://doi. org $/ 10.1021 / \mathrm{jm} 00112 \mathrm{a} 031$

[43] V. Zoete, A. Grosdidier, O. Michielin, Peroxisome proliferator-activated receptor structures: ligand specificity, molecular switch and interactions with regulators, Biochim. Biophys. Acta BBA - Mol. Cell Biol. Lipids. 1771 (2007) 915-925, https://doi.org/10.1016/j.bbalip.2007.01.007.

[44] R.A. Laskowski, M.B. Swindells, LigPlot+: multiple ligand-protein interaction diagrams for drug discovery, J. Chem. Inf. Model. 51 (2011) 2778-2786, https:// doi.org/10.1021/ci200227u.

[45] D.J. Parks, N.C.O. Tomkinson, M.S. Villeneuve, S.G. Blanchard, T.M. Willson, Differential activity of rosiglitazone enantiomers at PPAR $\gamma$, Bioorg. Med. Chem Lett 8 (1998) 3657-3658, https://doi.org/10.1016/S0960-894X(98)00664-7.

[46] I.N. Colmers, S.L. Bowker, J.A. Johnson, Thiazolidinedione use and cancer incidence in type 2 diabetes: a systematic review and meta-analysis, Diabetes Metab. 38 (2012) 475-484, https://doi.org/10.1016/j.diabet.2012.06.003.

[47] K.A. Szychowski, M.L. Leja, D.V. Kaminskyy, U.E. Binduga, O.R. Pinyazhko, R.B. Lesyk, J. Gmiński, Study of novel anticancer 4-thiazolidinone derivatives, Chem. Biol. Interact. 262 (2017) 46-56, https://doi.org/10.1016/j.cbi.2016.12. 008 .
[48] K.A. Szychowski, M.L. Leja, D.V. Kaminskyy, A.P. Kryshchyshyn, U.E. Binduga, O.R. Pinyazhko, R.B. Lesyk, J. Tobiasz, J. Gmiński, Anticancer properties of 4-thiazolidinone derivatives depend on peroxisome proliferator-activated receptor gamma (PPAR $\gamma$ ), Eur. J. Med. Chem. 141 (2017) 162-168, https: //doi.org/10.1016/j.ejmech.2017.09.071.

[49] S. Prost, F. Relouzat, M. Spentchian, Y. Ouzegdouh, J. Saliba, G. Massonnet, J.-P. Beressi, E. Verhoeyen, V. Raggueneau, B. Maneglier, S. Castaigne, C. Chomienne, S. Chrétien, P. Rousselot, P. Leboulch, Erosion of the chronic myeloid leukaemia stem cell pool by PPAR $\gamma$ agonists, Nature 525 (2015) 380-383, https://doi.org/10.1038/nature15248.

[50] S. Mazerbourg, S. Kuntz, I. Grillier-Vuissoz, A. Berthe, M. Geoffroy, S. Flament, A. Bordessa, M. Boisbrun, Reprofiling of troglitazone towards more active and less toxic derivatives: a new hope for cancer treatment?, Curr. Top. Med. Chem. 16 (2016) 2115-2124

[51] S. Salamone, C. Colin, I. Grillier-Vuissoz, S. Kuntz, S. Mazerbourg, S. Flament, H. Martin, L. Richert, Y. Chapleur, M. Boisbrun, Synthesis of new troglitazone derivatives: anti-proliferative activity in breast cancer cell lines and preliminary toxicological study, Eur. J. Med. Chem. 51 (2012) 206-215, https://doi.org/10. 1016/j.ejmech.2012.02.044

[52] M. Meyer, S. Foulquier, G. Monard, F. Dupuis, I. Grillier-Vuissoz, D. Henrion, S. Flament, Y. Chapleur, I. Lartaud, M. Boisbrun, New losartan derivatives with potential dual activity as angiotensin II receptor blocker and peroxisome proliferator activated receptor gamma activator, Ann. Cardiol. Angeiol 61 (2012) 11-12, ANCAAN-12-2012-61-1HS-0003-3928-101019-201206460.

[53] H.E. Gottlieb, V. Kotlyar, A. Nudelman, NMR chemical shifts of common laboratory solvents as trace impurities, J. Org. Chem. 62 (1997) 7512-7515, https:// doi.org/10.1021/jo971176v.

[54] G.M. Morris, R. Huey, W. Lindstrom, M.F. Sanner, R.K. Belew, D.S. Goodsell, A.J. Olson, AutoDock4 and AutoDockTools4: automated docking with selective receptor flexibility, J. Comput. Chem. 30 (2009) 2785-2791, https://doi.org/10. $1002 / j c c .21256$.

[55] M.F. Sanner, A.J. Olson, J.-C. Spehner, Reduced surface: an efficient way to compute molecular surfaces, Biopolymers 38 (1996) 305-320, https://doi.org/10. 1002/(SICI)1097-0282(199603)38:3<305::AID-BIP4>3.0.CO;2-Y.

[56] The PyMOL Molecular Graphics System, Schrödinger, LLC, 2015. 